\title{
Metal-Organic Frameworks as selective or chiral oxidation catalysts
}

\author{
Karen Leus ${ }^{1}$, Ying-Ya Liu ${ }^{1,2}$ and Pascal Van Der Voort ${ }^{1 *}$ \\ 1 Center for Ordered Materials, Organometallics and Catalysis (COMOC), Department of Inorganic \\ and Physical Chemistry, Ghent University, Krijgslaan 281-S3, 9000 Ghent (Belgium) \\ 2 State Key Laboratory of Fine Chemicals, Dalian University of Technology, 116024, Dalian, China \\ * Pascal Van Der Voort; E-Mail: Pascal.Vandervoort@Ugent.be \\ Tel.: +32-9-264-44-42; Fax: +32-9-264-49-83
}

\begin{abstract}
Since the discovery of Metal Organic Frameworks (MOFs) in the early 1990, the amount of new structures has grown exponentially. A MOF typically consists of inorganic nodes that are connected by organic linkers to form crystalline, highly porous structures. MOFs have attracted a lot of attention lately, as the versatile design of such materials holds promises of interesting applications in various fields. In this review, we will focus on the use of MOFs as heterogeneous oxidation catalysts. MOFs are very promising candidates to replace homogeneous catalysts by sustainable and stable heterogeneous catalysts.

The catalytic active function can be either the active metal sites of the MOF itself or can be introduced as an extra functionality in the linker, a dopant or a "ship-in-a-bottle" complex. As the pore size, pore shape and functionality of MOFs can be designed in numerous ways, shape selectivity and even chiral selectivity can be created. In this review, we will present an overview on the state of the art of the use of MOFs as a heterogeneous catalyst in liquid phase oxidation reactions.
\end{abstract}

Keywords: Chiral, enantioselective, encapsulation, heterogeneous catalysis, Metal-Organic Frameworks, oxidation

\section{Introduction}

Selective catalytic oxidation and asymmetric catalytic oxidations are of industrial importance for fine chemical syntheses. A lot of homogeneous catalysts, which generally consist of metal centers surrounded by a variety of ligands, are still employed in many industrial processes. By varying the metal center and the surrounding ligands of these homogeneous catalysts, the chemo-, regio- and stereo-selectivity can be tuned. Although homogeneous catalysts have the advantage that the reagents can easily approach the catalytically active sites, the separation of the catalyst and products can be cumbersome and expensive. Furthermore, volatile solvents need to be used to recover the catalyst from the reaction mixture. For the design of a heterogeneous variant, several factors need to be taken into consideration. Obviously, the big advantage of a solid catalyst originates in the ease of separation and its recyclability. Nevertheless, for the design of a competitive heterogeneous catalyst, high diffusion dynamics, well-isolated active sites, no-leaching and the possibility of a versatile modification of the catalyst should also be taken into consideration. 
So far the most often utilized solid catalysts for oxidation reactions are metals, metal oxides or metal complexes immobilized on zeolites, silica, alumina or polymeric resins ${ }^{1}$. Based on the interaction between the catalyst and the solid support, four common methods for the immobilization of homogeneous catalysts can be identified: covalent binding, electrostatic interaction, adsorption and encapsulation. These heterogeneous systems have some well documented disadvantages: (1) the poor dispersion of the (transition) metal oxides on the support, often coalescing to form crystals on the surface and (2) the weak metal-to-support bonding, which result in a significant leaching of the active metal species into the solution ${ }^{2}$.
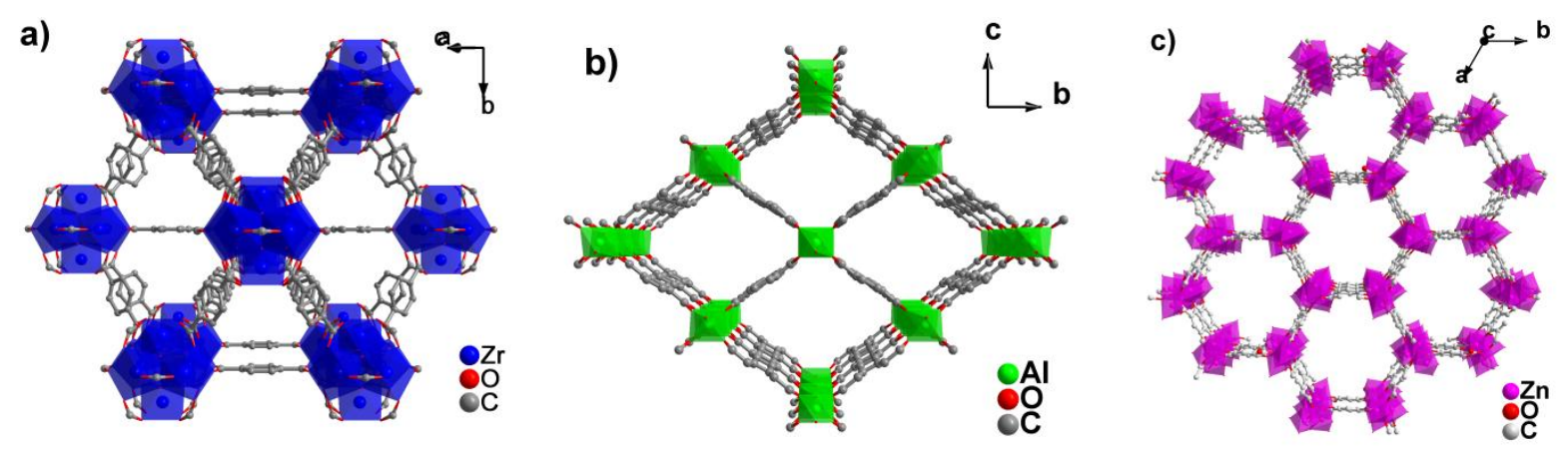

Figure 1. Examples of MOFs with different shapes of pores and channels a) UiO-66 ${ }^{3}$, b) MIL-53 ${ }^{4}$, c) MOF-74 $4^{5}$.

Metal Organic Frameworks (MOFs) are 3D crystalline atomically ordered materials, with an almost unlimited choice of building bricks, allowing a very precise control over morphology, pore size and functionalities in the walls ${ }^{67}$. In Figure 1, some MOFs structures with different shapes of pores and channels are illustrated. The crystalline nature of MOFs and high geometric regularity allows a full characterization and therefore a thorough understanding of their behavior is possible. MOFs have typically large surface areas with almost no limitations to the surface areas and pore size (so far the maximum pore aperture is $98 \AA$, surface area extending beyond $\left.7000 \mathrm{~m}^{2} / \mathrm{g}\right)^{8}$. Moreover, MOFs are highly designable due to the chemical versatility and the secondary building blocks that helps to build up the framework ${ }^{9}$. Due to their attractive properties, many research groups started to explore these materials for several applications. Especially gas storage, gas separation and heterogeneous catalysis are research themes that are quickly emerging ${ }^{10}$.

Research groups are now starting to fully realize the potential of MOFs as heterogeneous catalysts. They have been successfully used as catalysts in hydrogenation and oxidation reactions ${ }^{11}$ enantioselective reactions, ${ }^{12}$ photo catalysis, ${ }^{13}$ and hydrodesulfurization ${ }^{14}$. The highly tunable structure allows the MOF to act both as heterogeneous catalyst and as solid support. MOFs with unsaturated metal centers can be directly used as heterogeneous catalyst. For example, MIL- $101^{15}(\mathrm{Fe}, \mathrm{Cr}, \mathrm{Al})$ (MIL stands for Matériaux de l'Institut Lavoisier) and HKUST-1(Cu) ${ }^{16}$ (HKUST stands for The Hong Kong University of Science \& Technology), which both contain unsaturated metal centers at the nodes of the framework have shown good catalytic activity in a wide range of reactions ${ }^{17}$ (see Figure 2). For non-catalytic active MOFs, catalytic sites can be introduced by pre-/post-synthetic modification ${ }^{18}$. By using the "ship-in-bottle" approach, catalytically active metal complexes, polyoxometallic clusters or nanoparticles can be encapsulated inside the MOF cavities ${ }^{17 a, 19}$. Furthermore, by pre-/post-synthetic modification on the organic linker, complementary catalytic activity can be introduced ${ }^{20}$. With all these 
efforts, MOF materials can, in principle, combine different catalytic functions in which the unsaturated metal centers can provide Brönsted or Lewis acidity and basicity, or redox active centers. The finetunable cavity size (from microporous to mesoporous) permits shape selectivity by avoiding the formation of undesired intermediates or product.

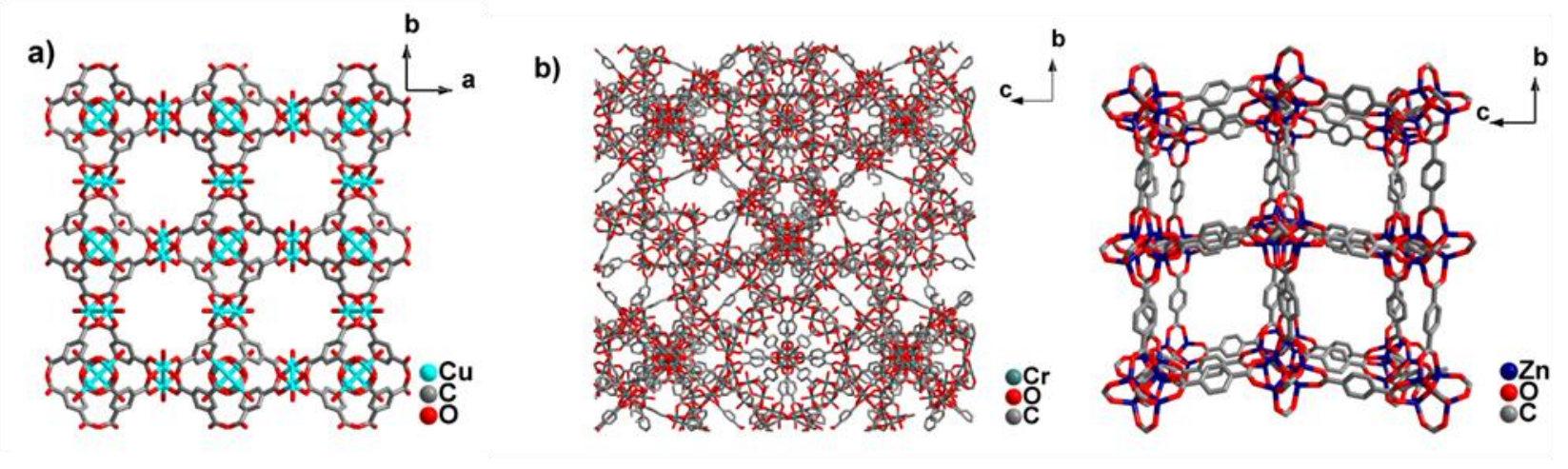

Figure 2. some examples of MOFs used as catalysts for selective oxidations reactions: a) HKUST-1 ${ }^{16}$, b) MIL-101 ${ }^{15}$, c)

$$
\text { MOF-5 (IRMOF-1) }{ }^{7 \mathrm{a}} \text {. }
$$

Despite of their unique features, MOFs also possess some limitations which restrict their use in heterogeneous catalysis. MOFs have a limited thermal and chemical stability (the majority cannot survive temperatures higher than $350{ }^{\circ} \mathrm{C}$ ) and MOFs have shown to hold a limited stability towards water and moisture. A few MOFs however are very stable in moist atmosphere and water, the most important topologies are UiO-66 (Zr) and MIL-100/MIL-101 (especially the Cr-variants).

The use of MOFs as heterogeneous catalysts in a very broad field has been covered in several reviews in the range of 2009 2011 ${ }^{14,21}$. In 2011, the group of Garcia ${ }^{22}$ has selectively summarized the use of MOFs as heterogeneous catalysts in oxidation reactions employing hydroperoxides or dioxygen. Very recently, the same group published a mini-review on the use of MOFs as heterogeneous catalysts for the production of fine chemicals ${ }^{23}$. In this present review we want to present a comprehensive overview of metal-organic frameworks for selective and chiral oxidation catalysis. We will provide empirical formulas as simplified representations of the MOF structures since considerable information is usually required to well describe the structure, meanwhile the reader is referred each time to the original publication for a better understanding of the structure. Firstly the different oxidants will be described as each oxidant will lead to different reaction pathways. Secondly an overview of the reported MOFs in catalyzing different types of oxidation reactions will be presented.

\subsection{Oxidation in the presence of pure $\mathrm{O}_{2}$ and/or $\mathrm{H}_{2} \mathrm{O}$}

Clearly gaseous $\mathrm{O}_{2}$, often referred to as molecular oxygen or dioxygen, is the most desired oxidant due to its availability and low cost. The most known catalytic system that can use molecular oxygen directly and efficiently is bulk silver ${ }^{24}$. This is achieved by dissociative adsorption into atomic oxygen species (Scheme 1), which will give rise to selective epoxidation products. 


$$
\mathrm{O}_{2}+4 \mathrm{Ag} \rightarrow 2 \mathrm{O}^{2 \cdot}{ }_{\text {ads }}+4 \mathrm{Ag}^{+}
$$
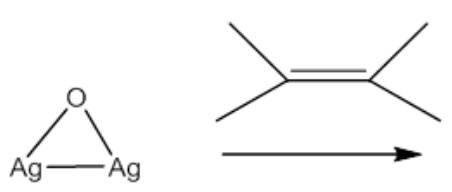

Scheme 1. Oxametallacycle mechanism for Ag catalysts, adapted from ref ${ }^{24}$.

By illumination of semi-conductors by an artificial or natural light in water (=photo catalysis), highly oxidizing $\mathrm{OH}^{\cdot}$ radicals can be created, which can be good oxidants. In Scheme 2, the basic mechanism of photo catalysis is shown for $\mathrm{TiO}_{2}$. Many efforts have been devoted to clarify the oxidizing species generated at the irradiated $\mathrm{TiO}_{2}$ surface. Oxidizing species, which have been suggested, include holes, $\mathrm{OH}$ and $\mathrm{O}_{2}^{-} \cdot$ radicals, among others ${ }^{25}$. In first instance, in the basic process of photo catalysis, an electron is ejected from the valence band (VB) to the conduction band (CB) of the $\mathrm{TiO}_{2}$ semiconductor, creating $\mathrm{a} \mathrm{h}^{+}$hole in the valence band (eq. 1 Scheme 2) due to UV irradiation of $\mathrm{TiO}_{2}$ with an energy equal or superior to the band gap. This is followed by formation of extremely reactive radicals (like $\cdot \mathrm{OH}$ ) and direct oxidation of the organic reactant. Furthermore, the ejected electrons react with electron acceptors such as molecular oxygen, which is dissolved in water (eq. 3 Scheme2) ${ }^{26}$. These can in turn be oxidizing species.

$$
\begin{aligned}
& \mathrm{TiO}_{2}+\mathrm{hv} \rightarrow \mathrm{e}_{\mathrm{cb}+}^{-} \mathrm{h}^{+}{ }_{\mathrm{vb}} \\
& \mathrm{h}^{+}{ }_{\mathrm{vb}}+\mathrm{H}_{2} \mathrm{O} \rightarrow{ }^{-} \mathrm{OH}+\mathrm{H}^{+} \\
& \mathrm{e}_{\mathrm{cb}}^{-}+\mathrm{O}_{2} \rightarrow \mathrm{O}_{2}^{-}
\end{aligned}
$$

Scheme 2. Basic process of photo catalysis ${ }^{26}$.

\subsection{Oxidation in the presence of $\mathrm{O}_{2}$ and aldehyde}

The oxidation of alkenes in the presence of an aldehyde and $\mathrm{O}_{2}$ appears to proceed via a mechanism related to aldehyde autoxidation, as can be seen in Scheme 3. In other words, the aldehyde plays a sacrificial role and undergoes co-oxidation (see eq. 1 and 2 Scheme 3). From literature, it is concluded that the predominant oxidizing species is an acylperoxy radical (see eq. 2 Scheme 3 ) ${ }^{27}$. These radicals are known to preferentially react with the double bonds of alkenes yielding epoxides, whereas hydroxyl and alkylperoxy radicals tend to abstract allylic hydrogens, resulting in allylic oxidation products.

\subsection{Oxidation in the presence of hydrogen peroxide or organic peroxides}

In most catalytic systems the oxygen needs to be activated in some form. Examples of products of direct activation are hydrogen peroxide or organic peroxides like tert-Butyl hydroperoxide (TBHP), which retain the $\mathrm{O}-\mathrm{O}$ bond. Hydrogen peroxide is an environmental friendly oxidant because the only by-product is water. It is, however, very hazardous to handle. In Scheme 4 an epoxidation mechanism is shown for a Mo based catalyst in the presence of $\mathrm{H}_{2} \mathrm{O}_{2}$. Early transition metal ions in their highest oxidation state, such as Ti(IV), V(V), W(VI) and Mo(VI), tend to be stable toward changes in their oxidation state. 
Consequently, in epoxidation reactions with $\mathrm{H}_{2} \mathrm{O}_{2}$ or alkylhydroperoxides, they form adducts (M-OOH and M-OOR). These adducts are the key intermediates in the epoxidation, and the role of the metal ion is that of a Lewis acid. The metal center acts as a Lewis acid by removing charge from the O-O bond, facilitating its dissociation, and activating the nearest oxygen atom (proximal oxygen) for insertion into the olefin double bond, whereas the distal oxygen constitutes a good leaving group in the form of OH or -OR (see Scheme 4$)^{24}$.
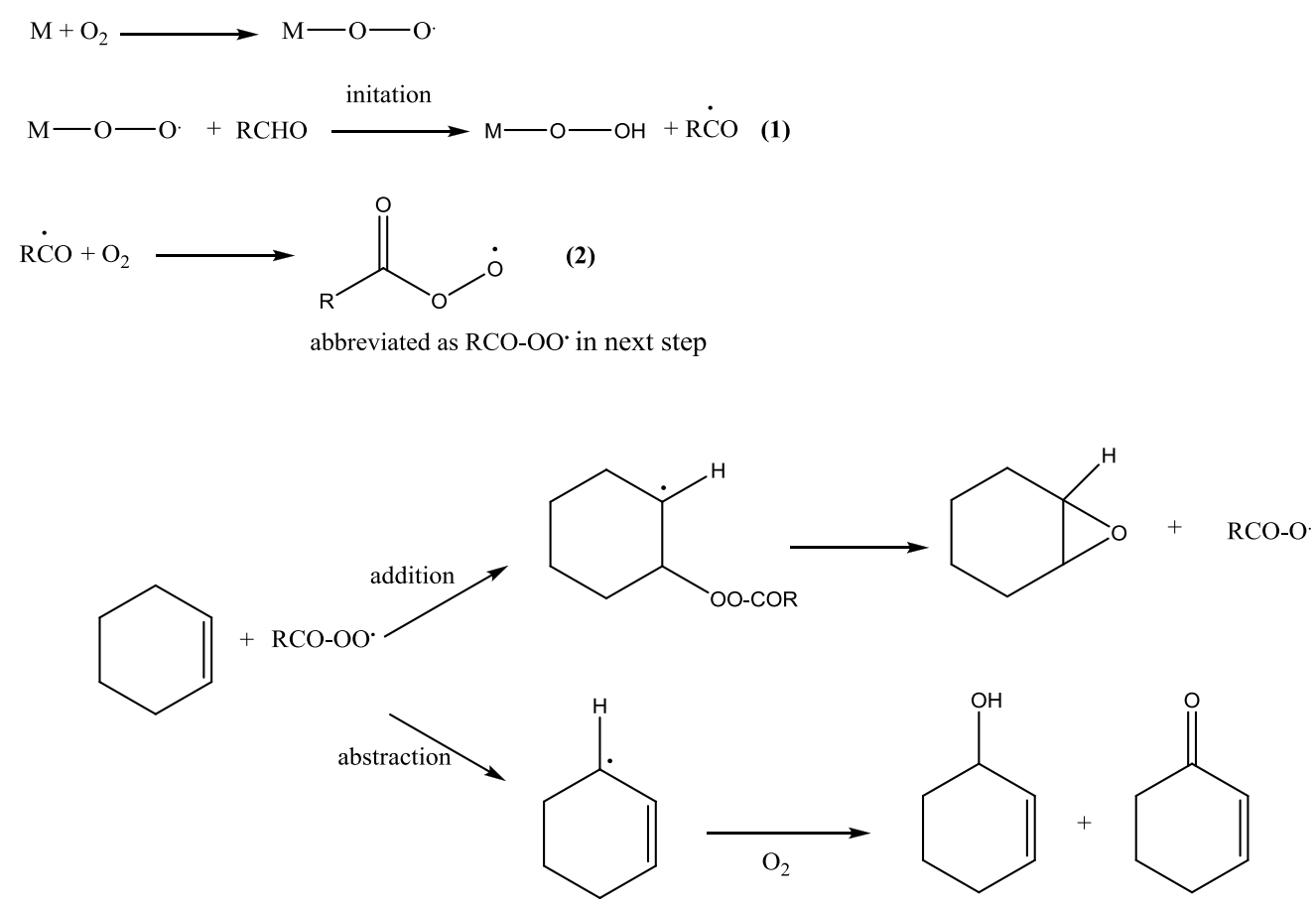

Scheme 3. General mechanism for the oxidation of cyclohexene with $\mathrm{O}_{2}$ and aldehyde (RCHO) inspired by ref ${ }^{27 b}$.
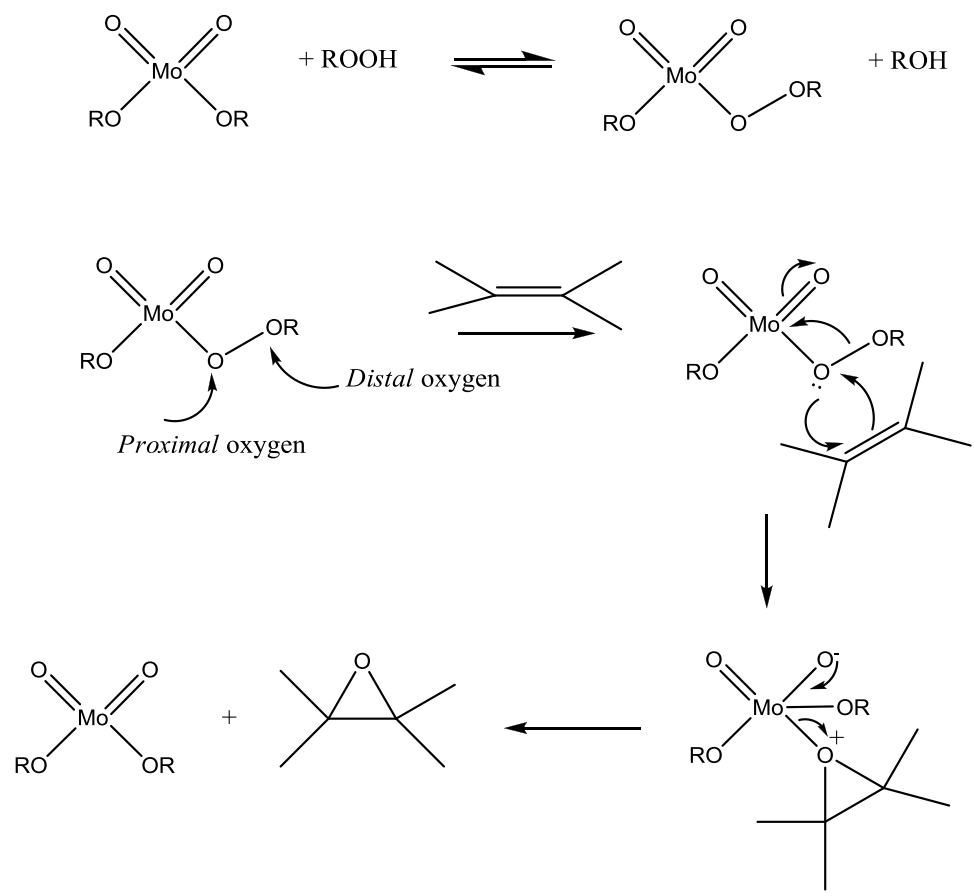

Scheme 4. Alkylperoxo mechanism of Mo-catalyzed epoxidation with hydroperoxides adapted from ref. ${ }^{24}$.

\subsection{Oxidation in the presence of $\mathrm{N}_{2} \mathrm{O}$, iodosyl aromatics and hypochlorite}


Other examples of oxidants are $\mathrm{N}_{2} \mathrm{O}$, iodosyl aromatics and hypochlorite, which contain a single oxygen atom in a highly activated state. With these oxidants, a single oxygen atom is transferred to a metal ion to form a high oxidation state metal-oxo species $(\mathrm{M}=\mathrm{O})$, which in turn delivers the same oxygen to the reactant. These single oxygen transfers are seen in certain coordination compounds of Fe, $\mathrm{Mn}$, and $\mathrm{Cr}$, in which the metal undergoes successive oxidation state changes ${ }^{24}$.

\section{MOFs in oxidation catalysis}

\subsection{Oxidation of cycloalkanes and benzylic compounds}

The selective oxidation of saturated hydrocarbons is one of the most challenging and interesting subjects in catalytic chemistry, due to the inertness of the $\mathrm{C}-\mathrm{H}$ bond and the huge added value of the functionalized products. In particular, the oxidation of cyclohexane towards cyclohexanol or cyclohexanone (KA oil) is a very important industrial process. In conventional industrial methods, the oxidation of cyclohexane is performed by a cobalt-based homogeneous catalyst. In recent years heterogeneous systems have been developed, using either metal nanoparticles or metalloporphyrins ${ }^{28}$. In an ideal case, these systems can activate molecular oxygen under mild conditions.

Similar reasonings apply to benzylic compounds. A variety of homogeneous and heterogeneous catalysts have been investigated for the oxidation of benzylic compounds (often the relevant oxidation of tetraline to $\alpha$-tetralone) using environmentally friendly oxidants. A large number of metals $(\mathrm{Cr}, \mathrm{Mn}$, $\mathrm{Fe}, \mathrm{Co}, \mathrm{Ni}, \mathrm{Cu}, \mathrm{Pd}$ ) have been tested in homogeneous systems, particularly with the metal coordinated to $\mathrm{N}$-donor ligands, such as porphyrins, phtalocyanines and phenantrolines ${ }^{29}$.

Important progress in this area can be made if MOFs can be developed that contain either immobilized (ship in a bottle) analogues of such complexes or MOFs that actually have such ligands as struts in their structure.

The investigated MOFs for the oxidation of cycloalkanes and/or benzylic compounds are presented in Table 1. Still many reports use TBHP as oxidant (entries 1,3-5,7,13,17 Table 1). However, some studies discuss the oxidation under aerobic conditions (entries 2,6, 9,10, 12,14,15, 18 Table 1) or use $\mathrm{H}_{2} \mathrm{O}_{2}$ as an oxidant (entry 8,11 Table 1). From Table 1 it can be seen that tetralin is the most commonly used reactant (see Scheme 5).

First of all, Cr-MIL-101 has been evaluated for the oxidation of tetralin using TBHP or molecular oxygen in combination with trimethylacetaldehyde as an oxidant (entry 1 Table 1$)^{30}$ The use of TBHP afforded higher conversion, whereas higher selectivities toward 1-tetralone were obtained with molecular oxygen (93 vs. 86\%). In another study on the oxidation of tetralin, air was applied as the oxidant for the evaluation of the catalytic performance of a $\mathrm{Cu}$ and Co MOF (entry 2 Table 1$)^{29}$. A remarkable difference was detected between both catalysts due to the different catalytic behaviour of the central metal ions. Very recently, quantum chemical calculations were performed on these two MOFs to investigate the decomposition of the hydroperoxide, suggesting that surface catalysis may be dominant $^{31}$.

The influence of the metal ion on the oxidation performance was confirmed by the study of Dhakshinamoorthy et al. ${ }^{32}$ (entry 3 Table 1) in which a significant difference in activity between $\mathrm{Fe}(\mathrm{BTC}), \mathrm{Cu}_{3}(\mathrm{BTC})_{2}$ and $\mathrm{Al}_{2}(\mathrm{BDC})_{2}$ was noticed. Furthermore, this report corroborated that the nature of the oxidant plays a crucial role. By means of $\mathrm{O}_{2}$ and $\mathrm{H}_{2} \mathrm{O}_{2}$ almost no oxidation of xanthene took place, while TBHP was a good oxidizing reagent in terms of the percentage yield to xanthone. Later 
on, these authors examined the influence of the particle size of $\mathrm{Fe}(\mathrm{BTC})$ on the oxidation performance. They concluded that for the bulky substrate, triphenylmethane, the average crystal size had a major impact on the activity: the smaller the particle size, the larger the initial reaction rate ${ }^{33}$. This evidences that in this case the reactant is unable to enter the pores of the MOFs matrix and the catalytic activity is only on the crystal surface.

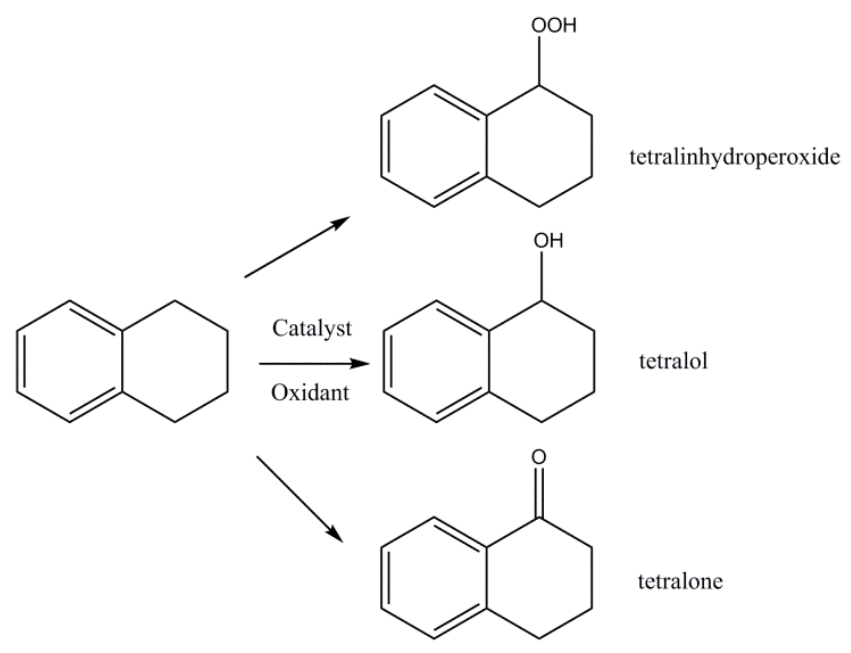

Scheme 5. Oxidation of tetralin toward tetralinhydroperoxide, tetralol and tetralone.

Instead of studying the influence of the metal centers, Wang et al. ${ }^{34}$ studied the influence of the anion exchange on the oxidation of diphenylmethane and tetralin for $\mathrm{Cu}$ based MOFs (entry 4 Table 1). As can be observed, a similar conversion of tetralin was obtained for both MOFs, whereas for the oxidation of the larger diphenylmethane a significantly higher conversion was detected for the $\mathrm{Cu}$ MOF-NO $\mathrm{N}_{3}$ in comparison to the $\mathrm{Cu}-\mathrm{MOF}-\mathrm{SiF}_{6}$, suggesting a certain size and shape selectivity. The authors stated that the openings of the channels may display a distinct recognition and response to different reactants, so in other words the catalytic activity is controlled by the size of the channels of the $\mathrm{Cu}-\mathrm{MOF}$ with the counter anion varying from $\mathrm{SiF}_{6}{ }^{2-}$ to $\mathrm{NO}_{3}{ }^{-}$.

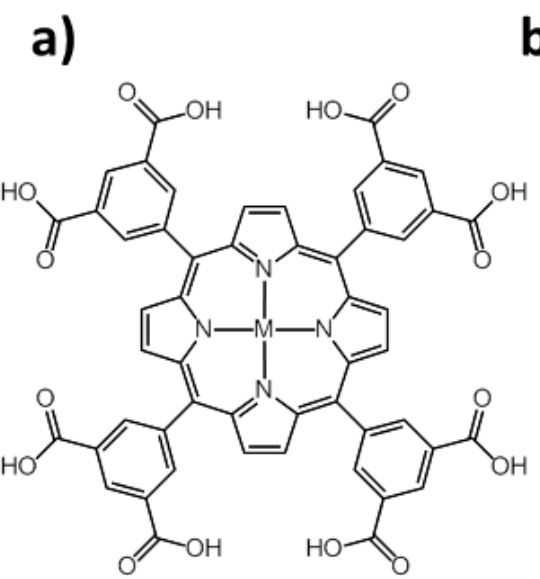

b)

c)
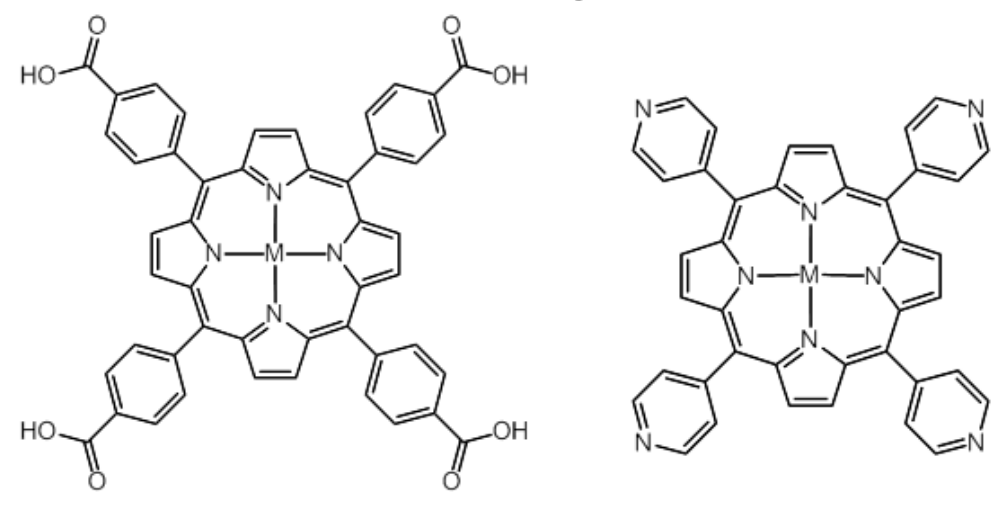

Scheme 6. a) 5,10,15,20-tetrakis(3,5-biscarboxylphenyl)porphyrin metalloligands; b) Tetrakis(4-carboxyphenyl) porphyrin metalloligands ( $\mathrm{M}^{\mathrm{III}}$-TCPP); c) 5,10,15,20-tetra(4-pyridyl)-porphyrin metalloligands $\left(\mathrm{M}^{\mathrm{IV}}\right.$ TPyP) 
Furthermore, some modified MOFs, obtained by the incorporation of species into the framework, were examined for the oxidation of cycloalkanes and/or benzylic compounds. Firstly, 4 POM based MOFs were tested for the oxidation of ethylbenzene (entry 5 Table 1$)^{35}$. Also, this report demonstrated that the metal center, more specifically the valence of the metal ion in the POM, can significantly influence the activity of the framework.

Secondly, $N$-hydroxyphthalimide (NHPI), a radical initiator, was embedded in $\mathrm{Fe}(\mathrm{BTC})$ which was explored for the oxidation of several benzylic compounds and alkanes (see entry 6 Table 1$)^{36}$. The authors assumed the occurrence of a radical oxidation mechanism with the aid of NHPI and the metal site of the MOF, which is widely known for the auto-oxidation of alkanes (see Scheme 7) ${ }^{37}$. Besides the oxidation of benzylic compounds and other alkanes, the NHPI@Fe(BTC) was also examined in the aerobic oxidation of benzylamines (entry 10 Table 1). Under mild conditions without the presence of a cosolvent, very good conversions (comparable with supported gold nanoparticles) were obtained ${ }^{38}$. Later on, the group of Garcia incorporated the same radical initiator in a Co-based MOF matrix (entry 9 Table 1) as it is well known that NHPI in combination with $\mathrm{Co}^{2+}$ salts is a strong homogeneous catalyst in oxidation catalysis ${ }^{39}$. In comparison with their former study, the Co-host exhibited a lower activity but a higher selectivity toward the ol/one was observed at the same substrate conversion ${ }^{39 b}$.

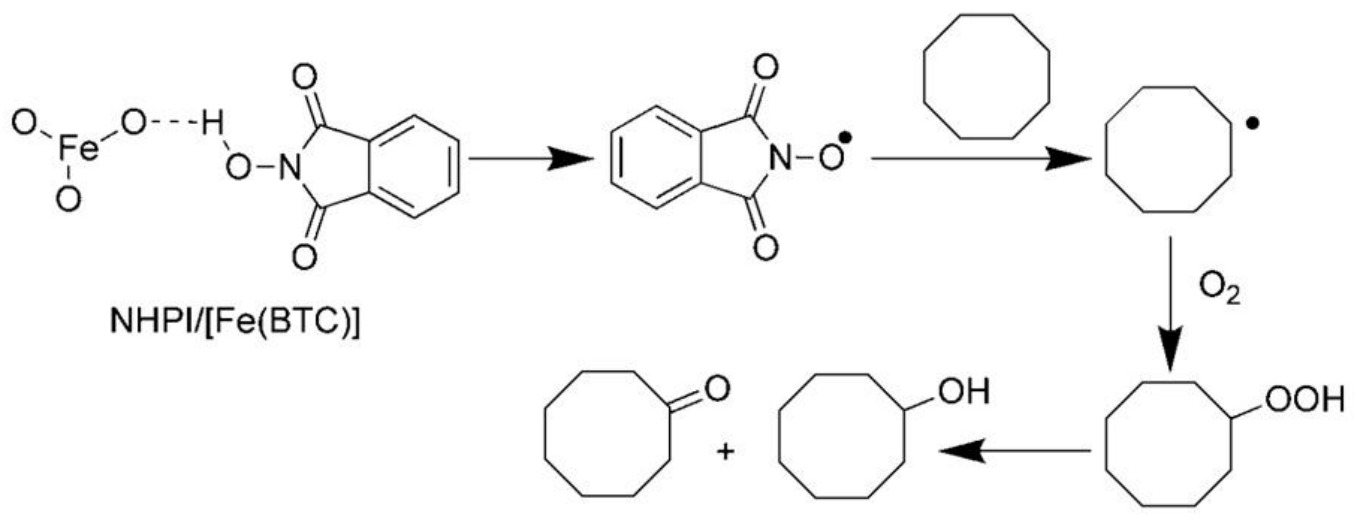

Scheme 7. Proposed mechanism for the oxidation of cyclooctane catalysed by NHPI@Fe(BTC) reproduced with permission from ref ${ }^{36}$. Copyright 2011 WILEY-VCH Verlag GmbH \& Co. KGaA, Weinheim.

Very interestingly, several porous metalloporphyrinic frameworks have been designed for certain catalytic applications. ${ }^{40}$ For instance, X. L. Yang et al. ${ }^{41}$ used carboxylate porphyrin metalloligands as the functional ligand (Scheme 6a) to build a series of porous metalloporphyrinic frameworks in $t b o$ topology (same topology as HKUST-1, pore window $\sim 11.5 \AA$, pore cage $\sim 21.3 \AA$ ). This open structure allows various substrates to reach the unsaturated metal centers. These metalloporphyrinic catalyst are highly efficient and show selective catalytic activity in the oxidation of alkylbenzenes. The porous catalyst shows substrate-selective properties. C. Zou et al. ${ }^{42}$ reported 4 other metalloporphyrinic frameworks build up from $\mathrm{M}_{2}{ }_{2}(\mathrm{COO})_{4}\left(\mathrm{M}^{\prime}=\mathrm{Zn}\right.$ or $\left.\mathrm{Cd}\right)$ paddle-wheel subunits bridged by $\mathrm{M}^{\mathrm{III}}$-TCPP (M= Fe or Mn) (Scheme 6 b) and formate ligands. Such MOFs show interesting catalytic properties in the selective epoxidation of olefins. The Mn-porphyrinic MOFs show full epoxidation of styrene in $\mathrm{CH}_{2} \mathrm{Cl}_{2}$ at $\mathrm{RT}$ within $6 \mathrm{~h}$, while the Fe-porphyrinic MOFs are quickly deactivated by self-oxidation (entry 28 , Table 4 ). They are also active in the oxidation of cyclohexane (20.6\% conversion) (entry 19 Table 1$)$. 
Recently, Xamena, Corma and co-workers ${ }^{43}$ reported several MOFs with $\mathrm{Cu}^{2+}$ centers linked to four nitrogen atoms from azaheterocyclic compounds. These materials are active catalysts for the aerobic oxidation of activated alkanes. Furthermore, a tandem reaction was designed using $\mathrm{Cu}-\mathrm{MOF}$ combined with silylated Ti-MCM-41 as solid catalyst, in which $\mathrm{Cu}-\mathrm{MOF}$ first catalyzed cumene oxidation to form cumene hydroperoxide as major product. Subsequently the intermediate hydroperoxide, together with silylated Ti-MCM-41 further catalyzed 1-octene to obtain 1-octene oxide. However, at high temperature $\left(90^{\circ} \mathrm{C}\right)$ the presence of $\mathrm{Cu}-\mathrm{MOF}$ will catalyze the oxidation of 1-octene at allylic position. Therefore, to increase the selectivity to the epoxide product, 1-octene and the $\mathrm{Cu}-\mathrm{MOF}$ were kept in separate reactors.

Finally, the report of Alkordi et al. ${ }^{19 \mathrm{~h}}$ described the encapsulation of a Mn-metallated porphyrin complex in an indium-imidazoledicarboxylate based MOF, rho-ZMOF (entry 7 Table 1). The resulting catalyst was explored for the oxidation of cyclohexane with TBHP as an oxidant, yielding a conversion of $91.5 \%$ after 24 hours of catalysis. 


\begin{tabular}{|c|c|c|c|c|c|c|c|c|}
\hline Entry & Catalytic MOF & Reactant & Oxidant & Reaction parameters & $\begin{array}{c}\text { Conversion } \\
(\%)\end{array}$ & Main product (selectivity) & Take home message & Ref. \\
\hline 1 & Cr-MIL-101 & Tetralin & $\begin{array}{l}\text { TBHP/ } \\
\mathrm{O}_{2}+\text { aldehyde }\end{array}$ & $\begin{array}{lll}60 \sim 100^{\circ} \mathrm{C}, & 8 \mathrm{~h} & \text { in } \\
\text { chlorobenzene }\end{array}$ & $55-73$ & Tetralone (86-93\%) & $\begin{array}{l}\text { Solvent and oxidant: influence on activity and } \\
\text { selectivity }\end{array}$ & 30 \\
\hline 2 & $\begin{array}{l}{\left[\mathrm{Cu}(2 \text {-pymo })_{2}\right]} \\
{\left[\mathrm{Co}(\mathrm{PhIM})_{2}\right](\mathrm{ZIF}-9)}\end{array}$ & Tetralin & Air & $\begin{array}{l}\text { Tetralin } / \text { metal molar } \\
\text { ratio: } 2000,90^{\circ} \mathrm{C} \text {, air } \\
\text { flow: } 0.5 \mathrm{~mL} / \mathrm{s}\end{array}$ & 52 & $\begin{array}{l}\text { Tetralinhydroperoxide } \\
\text { Tetralone }\end{array}$ & $\begin{array}{l}\text { No induction period, low selectivity toward ketone } \\
\text { Induction period, high selectivity toward ketone }\end{array}$ & 29 \\
\hline 3 & $\begin{array}{l}\mathrm{Fe}(\mathrm{BTC}) / \mathrm{Cu}_{3}(\mathrm{BTC})_{2} / \\
\mathrm{Al}_{2}(\mathrm{BDC})_{2} \\
\mathrm{Fe}(\mathrm{BTC})\end{array}$ & $\begin{array}{l}\text { Benzylic compounds } \\
\text { (tetralin, cyclooctane,...) }\end{array}$ & TBHP & $70^{\circ} \mathrm{C}, 24 \sim 88 \mathrm{~h}$ in $\mathrm{CH}_{3} \mathrm{CN}$ & $28-96$ & Ketone $(26-99 \%)$ & $\begin{array}{l}\mathrm{O}_{2} \text { and } \mathrm{H}_{2} \mathrm{O}_{2} \text { : inefficient to promote oxidation, } \\
\text { Influence of the metal ion on the activity: } \\
\mathrm{Fe}>\mathrm{Cu}>\mathrm{Al}\end{array}$ & 32 \\
\hline 4 & $\begin{array}{l}\mathrm{Cu}^{\mathrm{II}}(\text { bped })_{2}\left(\mathrm{H}_{2} \mathrm{O}\right)_{2}\left(\mathrm{SiF}_{6}\right) \\
\mathrm{Cu}^{\mathrm{II}}(\text { bped })_{2}\left(\mathrm{H}_{2} \mathrm{O}\right)_{2}\left(\mathrm{NO}_{3}\right)\end{array}$ & $\begin{array}{l}\text { Tetralin/ } \\
\text { Diphenylmethane }\end{array}$ & TBHP & $60^{\circ} \mathrm{C}, 36 \mathrm{~h}$ in $\mathrm{CH}_{3} \mathrm{CN}$ & $\begin{array}{l}88-92 \\
28-47\end{array}$ & $\begin{array}{l}\text { Tetralone }(71-77 \%) / \\
\text { Benzophenone }\end{array}$ & $\begin{array}{l}\text { Influence of the anion exchange: activity is } \\
\text { regulated by the size of the surface openings of } \mathrm{Cu}^{-} \\
\text {MOFs }\end{array}$ & 34 \\
\hline 5 & $\begin{array}{l}\left\{\left[\mathrm{Cu}_{2}\left(4,4^{\prime}-\text {-bipy }\right)_{4}\left(\mathrm{H}_{2} \mathrm{O}\right)_{4}\right]\right. \\
\left.\left(\mathrm{SiW}_{12} \mathrm{O}_{40}\right)\left(\mathrm{H}_{2} \mathrm{O}\right)_{18}\right\}_{\mathrm{n}} \\
\left\{\left[\mathrm{Cu}_{2}\left(4,4^{\prime} \text {-bipy }\right)_{4}\left(\mathrm{H}_{2} \mathrm{O}\right)_{4}\right]\left(\mathrm{SiW}_{12} \mathrm{O}_{40}\right)\right. \\
\left.\left(4,4^{\prime} \text {-bipy }\right)_{2}\left(\mathrm{H}_{2} \mathrm{O}\right)_{4}\right\}_{\mathrm{n}} \\
\left\{\left[\mathrm{Cu}_{2}\left(4,4^{\prime}-\text {-bipy }\right)_{4}\left(\mathrm{H}_{2} \mathrm{O}\right)_{4}\right]\left(\mathrm{PW}_{12} \mathrm{O}_{40}\right)\right. \\
\left(\mathrm{H}_{2} \mathrm{O}\right)_{18\}_{\mathrm{n}}} \\
\left\{\left[\mathrm{Cu}_{2}\left(4,4^{\prime}-\text { bipy }\right)_{4}\left(\mathrm{H}_{2} \mathrm{O}\right)_{4}\right]\left(\mathrm{PMo}_{12} \mathrm{O}_{40}\right)\right. \\
\left(\mathrm{H}_{2} \mathrm{O}\right)_{18\}_{\mathrm{n}}}\end{array}$ & Ethylbenzene & TBHP & $\begin{array}{l}40 \sim 70^{\circ} \mathrm{C}, \quad 6 \sim 24 \mathrm{~h} \text { in } \\
\mathrm{CH}_{3} \mathrm{CN}, \quad \text { ratio } \\
\text { TBHP/substrate }=1 \sim 3 \\
70^{\circ} \mathrm{C}, 12 \mathrm{~h} \text { in } \mathrm{CH}_{3} \mathrm{CN}\end{array}$ & $37.9-56.8$ & Acetophenone $(80.1-88.1 \%)$ & $\begin{array}{l}\text { The activity is influenced by the valence of the } \\
\text { metal }\end{array}$ & 35 \\
\hline 6 & NHPI@Fe(BTC) & $\begin{array}{l}\text { Benzylic } \\
\text { compounds,Linear } \\
\text { alkanes }\end{array}$ & $\mathrm{O}_{2}$ & $120^{\circ} \mathrm{C}, 2 \sim 24 \mathrm{~h}$ & 7-33 & Ketone & $\begin{array}{l}\text { No solvent, high selectivity toward alcohol and } \\
\text { ketone } \\
\text { Undergoes desactivation (formation of } \mathrm{FeO} \\
\text { nanoparticles) }\end{array}$ & 36 \\
\hline 7 & Mn-porhyrin@rho-ZMOF & Cyclohexane & ТВHP & $65^{\circ} \mathrm{C}, 24 \mathrm{~h}$ & 91.5 & Cyclohexanone & Stable up to 11 cycles & $19 \mathrm{~h}$ \\
\hline 8 & $\begin{array}{l}{\left[\mathrm{Cu}_{3}\left(\mu_{3}-\mathrm{OH}\right)\left(\mu^{-}\right.\right.} \\
\left.\mathrm{pz})_{3}(\mathrm{EtCOO})_{2}\left(\mathrm{H}_{2} \mathrm{O}\right)\right] \\
{\left[\mathrm{Cu}_{3}\left(\mu_{3}-\mathrm{OH}\right)\left(\mu^{-}\right.\right.}\end{array}$ & $\begin{array}{l}\text { Cyclohexane/ } \\
\text { cyclopentane }\end{array}$ & $\mathrm{H}_{2} \mathrm{O}_{2}$ & $\begin{array}{lcl}\mathrm{RT}, & 6 \mathrm{~h} & \text { in } \\
\mathrm{CH}_{3} \mathrm{CN}+\mathrm{HNO}_{3} & \end{array}$ & $\begin{array}{l}27.9 / 25.4 \\
25.6 / 31.0\end{array}$ & Alcohol & In absence of nitric acid: no activity & 44 \\
\hline 9 & $\begin{array}{l}\left.\mathrm{pz})_{3}(\mathrm{EtCOO})_{2}(\mathrm{EtOH})\right] \\
\mathrm{NHPI} @\left[\mathrm{Co}(\mathrm{DMA})_{6}\right]_{3} \\
{\left[\left(\mathrm{Co}_{4} \mathrm{Cl}\right)_{3}(\mathrm{BTT})_{8}\left(\mathrm{H}_{2} \mathrm{O}\right)_{12}\right]_{2 .} \cdot 12 \mathrm{H}_{2} \mathrm{O}}\end{array}$ & $\begin{array}{l}\text { Cycloalkanes and } \\
\text { benzylic compounds }\end{array}$ & $\mathrm{O}_{2}$ & $120^{\circ} \mathrm{C}, 1 \sim 29 \mathrm{~h}$ & $7-48$ & Ketone & $\begin{array}{l}\text { Higher selectivity toward ol/one compared to } \\
\text { former study (entry } 16-18 \text { ) }\end{array}$ & $39 \mathrm{~b}$ \\
\hline 10 & NHPI@Fe(BTC) & Benzylamines & $\mathrm{O}_{2}$ & $100^{\circ} \mathrm{C}, 10 \sim 24 \mathrm{~h}$ & 7-99 & Benzylimines & $\begin{array}{l}\text { Catalysis under mild and neutral conditions } \\
\text { without any cosolvent }\end{array}$ & 38 \\
\hline 11 & $\mathrm{Cu}-\mathrm{BTC}$ and $\mathrm{Cu}-\mathrm{BTC}-\mathrm{PyDC}$ & Toluene & $\mathrm{H}_{2} \mathrm{O}_{2}$ & $\begin{array}{l}40 \sim 80^{\circ} \mathrm{C}, \quad 1 \sim 18 \quad \mathrm{~h} \quad \text { in } \\
\mathrm{CH}_{3} \mathrm{CN}\end{array}$ & $0.14-4.91$ & - & High selectivity toward ortho and para product & $17 \mathrm{c}$ \\
\hline
\end{tabular}




\begin{tabular}{|c|c|c|c|c|c|c|c|c|}
\hline 12 & $\begin{array}{l}\mathrm{N}\left(\mathrm{FePc}^{\mathrm{t}} \mathrm{Bu}_{4}\right)_{2} @ \mathrm{MIL}-101 \\
\mathrm{FePcF}_{16} @ \mathrm{MIL}-101 \\
\mathrm{RuPcF}_{16} @ \mathrm{MIL}-101\end{array}$ & Tetralin & $\mathrm{O}_{2}$ & $\begin{array}{l}50 \sim 130{ }^{\circ} \mathrm{C}, \quad 6 \sim 10 \mathrm{bar}, \\
1 \sim 24 \mathrm{~h}, \text { solvent free }\end{array}$ & $\begin{array}{l}5100^{*} \\
24200^{*} \\
30900^{*}\end{array}$ & 1-tetralone & $\begin{array}{l}\text { Higher activity of the complex@MOF than the } \\
\text { homogeneous complex }\end{array}$ & 45 \\
\hline 13 & $\begin{array}{l}\mathrm{Mn}_{5} \mathrm{Cl}_{2}\left(\mathrm{Mnn}^{\mathrm{II}} \mathrm{Cl}-\mathrm{OCPP}\right. \\
\mathrm{ZJU}-18,)\end{array}$ & Alkylbenzenes & ТВHP & $65^{\circ} \mathrm{C} 18 \mathrm{~h}$ in $\mathrm{CH} 3 \mathrm{CN}$ & $16 \sim>99$ & Phenyl ketones & $\begin{array}{l}\text { ZJU- } 18 \text { shows highly selective oxidation of } \\
\text { ethylbenzene to acetophenone in }>99 \% \text { yield, }\end{array}$ & ${ }^{41}$ \\
\hline \multirow[t]{2}{*}{14} & \multirow[t]{2}{*}{$\mathrm{Au}-\mathrm{Pd} / \mathrm{MIL}-101$} & Toluene & $\mathrm{O}_{2}(1 \mathrm{MPa})$ & $\begin{array}{l}120 \quad{ }^{\circ} \mathrm{C}, \text { solvent free, } \\
48 \mathrm{~h} ; \quad \text { substrate/Metal } \\
=2200 \text { (Pd: } \mathrm{Au} \text { molar } \\
\text { ratio 1.5:1) }\end{array}$ & 75.6 & Benzylbenzoate (93\%) & \multirow{2}{*}{$\begin{array}{l}\text { High activity and selectivity are due to the } \\
\text { presence of bimetallic nanoparticles(activating O2) } \\
\text { as well as the lewis acidity of the MOF } \\
\text { support(activate the methyl group of toluene). } \\
\text { Meanwhile, the Lewis centre inhibits the further } \\
\text { oxidation of benzaldehyde to benzoic acid. }\end{array}$} & 46 \\
\hline & & $\begin{array}{l}\text { Aromatic } \\
\text { hydrocarbons(xylene, } \\
\text { methoxytoluene, } \\
\text { Fluorotoluene) }\end{array}$ & $\mathrm{O}_{2}(1 \mathrm{MPa})$ & $\begin{array}{l}120 \quad{ }^{\circ} \mathrm{C} \text {, solvent free, } \\
48 \mathrm{~h} ; \quad \text { substrate/Metal } \\
=3000 \text { (Pd: Au molar } \\
\text { ratio } 1.5: 1)\end{array}$ & $25.5 \sim 45.5$ & $\begin{array}{l}\text { Substituted } \\
(62 \sim 71 \%)\end{array}$ & & \\
\hline 15 & $\begin{array}{l}\mathrm{Al}(\mathrm{OH})(\mathrm{bpydc})=\mathrm{MOF}-253 \\
\text { (bpydc=2,2'-bipyridine- } 5,5^{\prime}- \\
\text { dicarboxylate) }\end{array}$ & $\begin{array}{l}\text { Various alkanes } \\
\text { e.g. cyclohexane }\end{array}$ & $\mathrm{O}_{2}(1 \mathrm{MPa})$ & $150^{\circ} \mathrm{C}$, solvent free, $4 \mathrm{~h}$ & 59.9 & Cyclohexanone (48.1) & $\begin{array}{l}\text { MOF-253(Al) can efficiently activate molecular } \mathrm{O}_{2} \\
\text { at high temperature }\end{array}$ & 47 \\
\hline 16 & $\begin{array}{l}\mathrm{Cu}(\mathrm{im})_{2}(\mathrm{im}=\text { imidazole) together } \\
\text { with silylated Ti-MCM-41 }\end{array}$ & $\begin{array}{l}\text { Tandem 1) cumene and } \\
\text { 2) 1-octene epoxidation }\end{array}$ & $\mathrm{O}_{2}$ and $\mathrm{TBHP}$ & $\begin{array}{l}\text { Two pot setup } \\
\text { 1) } 90^{\circ} \mathrm{C}, 4 \mathrm{~h} \\
\text { 2) } 90^{\circ} \mathrm{C} 24 \mathrm{~h}\end{array}$ & $\begin{array}{l}\text { Cumene: } \\
31 \\
\text { Octene } \\
18.1\end{array}$ & $\begin{array}{l}\text { Cumene hydroperoxide (24\%) } \\
\text { 1-octene oxide }(100 \%)\end{array}$ & $\begin{array}{l}\text { To increase the selectivity to the epoxide product, } \\
\text { 1-octene and the Cu-MOF was kept at separate } \\
\text { reactors }\end{array}$ & 43 \\
\hline 17 & V-CatBrO MOF & Tetralin & TBHP & $\begin{array}{l}50^{\circ} \mathrm{C} \text {, in chlorobenzene } \\
24 \mathrm{~h} \text { Tetralin: TBHP: } \\
\text { catalyst molar ratio } \\
\text { 100:100:1 }\end{array}$ & 45 & Tetralone $(\sim 75 \%)$ & \multicolumn{2}{|l|}{$\begin{array}{l}\text { Vanady(monocatecholate) are incorporated into a } \\
\text { dipyridyl struts of a } \mathrm{Zn} \text {-MOF, providing the } \\
\text { unsaturated } \mathrm{V} \text { centers for catalysis. }\end{array}$} \\
\hline 18 & $\begin{array}{l}\mathrm{Au} / \mathrm{MIL}-53(\mathrm{Cr}) \\
\mathrm{Au} / \mathrm{MIL}-101(\mathrm{Cr})\end{array}$ & cyclohexane & $\mathrm{O}_{2}(1.2 \mathrm{MPa})$ & $\begin{array}{l}130{ }^{\circ} \mathrm{C}, \quad 6 \mathrm{~h}, \text { solvent } \\
\text { free. }\end{array}$ & $30.5 \sim 31.3$ & Cyclohexanone $(81.9 \% \sim 87.7 \%)$ & $\begin{array}{l}\text { Both } \mathrm{Cr} \text { ions from MOF framework and } \mathrm{Au} \\
\text { nanoparticles act as catalytic sites for the } \\
\text { reaction. }\end{array}$ & 49 \\
\hline 19 & $\begin{array}{l}\left.\left(\mathrm{CH}_{3}\right)_{2} \mathrm{NH}_{2}\right]\left[\mathrm{Zn}_{2}(\mathrm{HCOO})_{2}\left(\mathrm{Mn}^{\mathrm{III}}-\right.\right. \\
\text { TCPP } \quad\left(\mathrm{H}_{6} \mathrm{TCPP}=\text { tetrakis }(4-\right. \\
\text { carboxyphen yl) porphyrin })\end{array}$ & cyclohexane & $\begin{array}{l}\mathrm{PhIO} \\
\text { (iodosobenzene) }\end{array}$ & $\mathrm{RT}, 6 \mathrm{~h}$ in $\mathrm{CH}_{2} \mathrm{Cl}_{2}$ & $20.6 \%$ & Cyclohexanone & $\begin{array}{l}\text { Catalysis happens on exterior sufaces due to the } \\
\mathrm{M}^{\mathrm{III}} \text { sites are ligated by formate pillars. }\end{array}$ & 42 \\
\hline
\end{tabular}

Table 1 Overview of the MOFs studied for the oxidation of cycloalkanes and/or benzylic compounds. 


\subsection{Oxidation of alcohols and hydroxylation of phenol}

\section{Oxidation of alcohols}

The oxidation of alcohols to carbonyl compounds is one of the most fundamental processes in organic synthesis $^{50}$. During the last decade, a number of green heterogeneous catalytic systems have been developed that use molecular oxygen or air as the oxidant ${ }^{51}$. These typically employ metal-based heterogeneous catalysts containing ruthenium, gold or platinum. However, many of these systems require harsh reaction conditions and substrate selectivity can be difficult to control. Oxidation reactions at room temperature in appropriate solvents are necessary for alcohols with high melting points or low stability at high temperatures, but examples of these room-temperature reactions are very limited $^{52}$. Oxidation catalysis with MOFs has been particularly productive over the past several years. The majority of these transformations have employed either metal nodes or encapsulated nanoparticles in the MOF as catalysts.

In Table 2 an overview is presented of the MOFs that have been examined for the oxidation of alcohols (including phenol). There is one report of a $\mathrm{Pd}$ based MOF, denoted as $\left[\mathrm{Pd}(2-\mathrm{pymo})_{2}\right]_{\mathrm{n}}$, studied for the aerobic oxidation of 3-phenyl-2-propen-1-ol (entry 1 Table 2$)^{53}$. A complete conversion of the alcohol was observed after a reaction time of $20 \mathrm{~h}$, with a selectivity of $74 \%$ toward the cinnamylaldehyde, which is comparable to other palladium-catalyzed oxidation reactions of allylic alcohols ${ }^{53}$. Furthermore, the research group of $\mathrm{Zou}^{20 \mathrm{~b}}$ reported for the first time the post-synthetic coordination of a Ru-complex onto MOF- $253^{54}$ (entry 8 Table 2). The resulting Ru@MOF-253 was examined in the oxidation of a variety of alcohols exhibiting high selectivities for ketones and aldehydes (up to 99\%) under mild reaction conditions. This is remarkable, as the selective oxidation of primary alcohols to aldehydes at room temperature with heterogeneous catalysts is still rather limited and represents a challenging area in green chemistry ${ }^{55}$.

Most other studies describe the loading of Au or Pt nanoparticles on a MOF. One report describes the gas-phase deposition of MOF-177 with Pt nanoparticles, denoted as Pt@MOF-177, which was studied for the aerobic oxidation of allylic and aliphatic alcohols at room temperature in a base and solventfree medium (entry 2 Table 2$)^{56}$. For most reactants very high conversions and selectivities were observed. However, it was not possible to recycle the catalyst. Due to the presence of water (which is a by-product in the oxidation of alcohols), the host framework was destroyed making the Pt particles inaccessible for further reaction ${ }^{56}$.

Also Dhakshinamoorthy et al. ${ }^{57}$ applied $\mathrm{O}_{2}$ as an oxidant to examine the catalytic performance of $\mathrm{Cu}_{3}(\mathrm{BTC})_{2}$ in combination with the radical initiator TEMPO as a co-catalyst (entry 3 Table 2). The authors observed a somewhat low reactivity for some substituted benzylic alcohols and other alcohols, which they attributed to the inability of reactants to reach the active sites and to catalyst deactivation by poisoning and/or pore blocking.

All the Au@MOF materials were studied for the oxidation of benzyl alcohol, a typical benchmark reaction. Very different conditions were used in the catalytic tests. Firstly, there is a lot of debate on the question if a base is required. For example, Müller et al. ${ }^{58}$ showed that if no base was added to the reaction mixture, the Au@MOF catalysts were inactive whereas in the presence of the base $\mathrm{K}_{2} \mathrm{CO}_{3}$, the oxidation reaction is accelerated by deprotonation of the alcohol. Nevertheless, in the report of Liu et al.59 on Au@MIL-101 (entry 7 Table 2), the catalyst already showed a high catalytic performance in 
the absence of a base which was the result of a high dispersion of the Au nanoparticles combined with a synergetic effect of the MIL-101 host matrix. It is suggested that the support may play a crucial role, either direct or indirect, in the determination of the activity of gold 2,60 . The influence of the support is also illustrated in the work of Ishida et $a l .{ }^{61}$ in which large differences in alcohol conversions are observed for the Au@MOF-5, Au@Al-MIL-53 and Au@ $\mathrm{Cu}_{3}(\mathrm{BTC})_{2}$ (entry 4 Table 2). Also in the work of Esken et al. ${ }^{21 a}$ (entry 5 Table 2), it was suggested that the Au nanoparticles may chemically interact with the functionalities on the organic linker. They observed a remarkable difference in catalytic activity between Au@ZIF-8, which exhibit a good conversion of $81 \%$ benzyl alcohol, whereas the Au@ZIF-90 shows a very weak activity (13\%). The latter is due to in situ oxidation of the aldehyde functions of ZIF-90 by means of the Au nanoparticles imbedded in the MOF, making the active $\mathrm{Au}$ sites inaccessible for further reaction. ${ }^{21 \mathrm{a}}$

\section{Hydroxylation of Phenol}

For the hydroxylation of phenol, completely different catalysts are required. Phenol hydroxylation is an oxidation of phenol by hydrogen peroxide to produce two benzenediols: catechol (benzene-1,2-diol) and hydroquinone (benzene-1,4-diol). They can be produced in industrial scales by using homogeneous acid catalysts at $40-90{ }^{\circ} \mathrm{C}$, but the homogeneous catalysts are difficult to separate from the reaction mixture making their recovery and recycling almost impossible ${ }^{62}$.

Several researchers have tried to develop heterogeneous catalysts for phenol hydroxylation. Transition metal oxides such as iron $(\mathrm{Fe})$, copper $(\mathrm{Cu})$ and cobalt $(\mathrm{Co})$ on various support materials have been tested and $\mathrm{Fe}$ has been the most widely investigated. When supported on various zeolites including ZSM-5, NaY, MOR, the phenol conversions were less than $40 \%$ in all Fe catalysts and only Fe/MOR gave $100 \%$ catechol selectivity. This information inferred that the shape and size of pores of the supports influenced the product selectivity ${ }^{63}$.

Most reports that discuss the hydroxylation of phenol, use $\mathrm{H}_{2} \mathrm{O}_{2}$ as an oxidant (entry 9-12, Table 2). Some reports discuss the use of a metal-phenanthroline based complex encapsulated in a MOF (entry 10-11, Table 2). Besides the use of a similar homogeneous complex, some other common conclusions can be drawn from these studies ${ }^{64}$. Firstly, almost no activity was observed applying 1-naphthol as substrate. The authors attributed this finding to the large dimensions of the substrate, preventing it's diffusion through the framework. Secondly, a remarkably high selectivity toward hydroquinone was noticed which was contrary to the selectivity of the homogeneous catalyst. The authors assumed that the reaction took place in the channels of the framework and concluded a reactant shape selectivity.

Apart from these studies, Bhattacharjee et al. ${ }^{65}$ (entry 9, Table 2) examined Fe-MOF-74 in the oxidation of phenol, showing a high selectivity towards catechol (68\%) whereas the study of Jian et al. (entry 12, Table 2) applied a Cu-MOF which exhibited good selectivity towards benzoquinone. So far, however, the Fe-MOF systems have not yet proven to perform better than the Fe@mordenite zeolitic systems ${ }^{66}$.

It should be noted that many metalloporphyrins present distinct photo catalytic activity in the homogeneous phase, however, investigation of the photo catalytic properties of metalloporphyrinbased MOFs are rare. Xie M.-H. et al. ${ }^{67}$ reported a MOF which is constructed from 5,10,15,20-tetra(4pyridyl)-tin(IV)-porphyrin ( $\left.\mathrm{Sn}^{\mathrm{IV}} \mathrm{TPyP}\right)$ (Scheme 6c) and formate linking up zinc atoms, which presents excellent photo catalytic activities for phenol and sulfide oxygenations (entry 16, Table 3). A selective 
photo-oxygenation of 1,5-dihydroxynaphthalene in the presence of a tin(IV)-porphyrin based MOF was performed in the optimized solvent of $\mathrm{CH}_{2} \mathrm{Cl}_{2} / \mathrm{MeOH}(4: 1, \mathrm{v} / \mathrm{v})$. The substrate could be fully oxidized into 5-hydroxynaphthalene-1,4-dione, The high conversion is attributed to $\mathrm{CH}_{2} \mathrm{Cl}_{2}$ being able to prolong the lifetime of the singlet oxygen $\left({ }^{1} \mathrm{O}_{2}\right.$ ) (entry 16, Table 2).

The application of MOFs in photo catalysis is emerging as an interesting topic. However, a lot of MOFs need either the assistance of a sacrificial agent or UV-light as energy source. Recently, several research groups performed a photo catalytic study of an amine-functionalized $\mathrm{Zr}-\mathrm{MOF}$, UiO-66- $\mathrm{NH}_{2}$ (Figure 2d). For instance, J. Long et al. ${ }^{68}$ reported that under visible light irradiation, UiO-66- $\mathrm{NH}_{2}$ catalyzes the aerobic oxidation of alcohols, olefines and cyclic alkanes. In benzyl alcohol, cyclohexanol and hexyl alcohol oxidation catalysis, 100\% selectivity is achieved for these substrates (entry 13, Table 2), but the conversion rate highly depends on the activation energy of $\alpha$-C-H bonds. The authors also studied the influence of solvents, the result shows that polar organic media play a crucial role in stabilizing the intermediate epoxides and active oxygen species. The mechanism of the photo catalytic process was proposed based on the in-situ EPR characterization, which determine the active intermediates, the $\mathrm{O}_{2}^{--}$formed during irradiation are adsorbed on $\mathrm{Zr}^{3+}$ sites, and can be stabilized in the cavities of UiO-66- $\mathrm{NH}_{2}$ its interaction with the amine groups and/or organic solvents, which consequently benefits the photo catalytic process. 
Table 2. Overview of the MOFs investigated for the oxidation of alcohols and hydroxylation of phenol.

\begin{tabular}{|c|c|c|c|c|c|c|c|c|}
\hline Entry & Catalytic MOF & Reactant & Oxidant & $\begin{array}{c}\text { Reaction } \\
\text { parameters }\end{array}$ & $\begin{array}{c}\text { Conversion } \\
(\%)\end{array}$ & $\begin{array}{c}\text { Main product } \\
\text { (selectivity) }\end{array}$ & Take home message & Ref. \\
\hline 1 & {$\left[\operatorname{Pd}(2-\text { pymo })_{2}\right]_{n}$} & 3-phenyl-2-propen-1-ol & Air & $\begin{array}{l}90^{\circ} \mathrm{C}, \quad 20 \quad \mathrm{~h} \text { in } \\
\text { toluene }\end{array}$ & $>99$ & $\begin{array}{l}\text { 3-phenylprop-2-enal } \\
(74 \%)\end{array}$ & $\begin{array}{l}\text { Selectivity similar to } \mathrm{Pd} \text { based } \\
\text { catalysts }\end{array}$ & 53 \\
\hline 2 & Pt@MOF-177 & Allylic and aliphatic alcohols & Air & $\begin{array}{l}\text { Solvent- and base- } \\
\text { free, RT, } 24 \mathrm{~h}\end{array}$ & $>99$ & Ketone or aldehyde & $\begin{array}{l}\text { RT, solvent }- \text { and base-free } \\
\text { conditions, not recyclable }\end{array}$ & 56 \\
\hline 3 & $\mathrm{TEMPO} / \mathrm{Cu}_{3}(\mathrm{BTC})_{2}$ & Benzyl alcohol & $\mathrm{O}_{2}$ & $\begin{array}{l}40 \sim 75{ }^{\circ} \mathrm{C}, 22 \sim 44 \mathrm{~h} \\
\text { in } \quad \mathrm{CH}_{3} \mathrm{CN}+\end{array}$ & 90 & $\begin{array}{l}\text { Benzaldehyde } \\
(>98 \%)\end{array}$ & $\begin{array}{l}\text { Deactivation by poisoning and/or } \\
\text { pore blocking }\end{array}$ & 57 \\
\hline 4 & $\begin{array}{l}\mathrm{Au} @ \mathrm{MOF} 5 / \mathrm{Au} @ \mathrm{Al}-\mathrm{MIL}-53 \\
\mathrm{Au} @ \mathrm{Cu}_{3}(\mathrm{BTC})_{2}\end{array}$ & $\begin{array}{l}\text { Benzyl alcohol and 1- } \\
\text { phenylethanol }\end{array}$ & $\mathrm{O}_{2}$ & $\begin{array}{l}\mathrm{Na}_{2} \mathrm{CO}_{3} \\
800^{\circ} \mathrm{C}, 30 \text { min in } \\
\mathrm{MeOH}+\mathrm{K}_{2} \mathrm{CO}_{3} \text { at } \\
5 \text { bar }\end{array}$ & $\begin{array}{l}56-99 \\
70\end{array}$ & $\begin{array}{l}\text { Methyl benzoate } \\
\text { Benzaldehyde }\end{array}$ & $\begin{array}{l}\text { Influence of MOF support on the } \\
\text { activity }\end{array}$ & ${ }^{61,58}$ \\
\hline 5 & Au@ZIF-8 and Au@ZIF-90 & Benzyl alcohol & $\mathrm{O}_{2}$ & $\begin{array}{l}80{ }^{\circ} \mathrm{C}, 24 \mathrm{~h} \text { in } \\
\mathrm{MeOH} \text { at } 5 \mathrm{bar}\end{array}$ & $13-81$ & $\begin{array}{l}\text { Methyl benzoate }(50- \\
(98 \%)\end{array}$ & $\begin{array}{l}\text { Side reaction: oxidation of } \\
\text { functional groups in framework by } \\
\mathrm{Au}\end{array}$ & 21a \\
\hline 6 & $\mathrm{Au} / \mathrm{ZnO} @ \mathrm{MOF}-5$ and $\mathrm{Au} / \mathrm{TiO}_{2} @ \mathrm{MOF}-5$ & Benzyl alcohol & $\mathrm{O}_{2}$ & $\begin{array}{l}80{ }^{\circ} \mathrm{C}, 30 \text { min in } \\
\mathrm{MeOH}+\mathrm{K}_{2} \mathrm{CO}_{3} \text { at } \\
5 \text { bar }\end{array}$ & $68-74$ & Methyl benzoate & $\begin{array}{l}\text { Au/oxide@MOF-5: higher activity } \\
\text { and selectivity than Au@MOF-5 }\end{array}$ & 58 \\
\hline 7 & Au@MIL-101 & $\begin{array}{l}\text { Benzylic alcohols, allylic } \\
\text { alcohols and aliphatic alcohols }\end{array}$ & $\mathrm{O}_{2}$ & $\begin{array}{l}80{ }^{\circ} \mathrm{C}, \quad 1 \text { atm, } \\
1 \sim 35 \mathrm{~h} \text { in toluene }\end{array}$ & $23-99$ & $\begin{array}{l}\text { Aldehyde or ketone } \\
(>99 \%)\end{array}$ & $\begin{array}{l}\text { High activity, selectivity, } \\
\text { recyclability in absence of base or } \\
\text { water }\end{array}$ & 59 \\
\hline 8 & Ru@MOF-253 & Primary/secondary alcohols & $\mathrm{PhI}(\mathrm{Oac})_{2}$ & $\begin{array}{l}22 \sim 40^{\circ} \mathrm{C}, 1.5 \sim 5 \mathrm{~h} \\
\text { in } \mathrm{CH}_{2} \mathrm{Cl}_{2}\end{array}$ & $55-99$ & Ketone or aldehyde & $\begin{array}{l}\text { At RT: high conversions and } \\
\text { selectivities }(>90 \%)\end{array}$ & $20 \mathrm{~b}$ \\
\hline 9 & Fe-MOF-74 & Phenol & $\mathrm{H}_{2} \mathrm{O}_{2}$ & $\begin{array}{l}\text { Mol ratio } \\
\text { phenol: } \mathrm{H}_{2} \mathrm{O}_{2}= \\
1: 0.33 \sim 1: 1, \\
20{ }^{\circ} \mathrm{C} \text { in } \mathrm{H}_{2} \mathrm{O}\end{array}$ & 60 & Catechol (68\%) & $\begin{array}{l}\text { Higher conversion to useful } \\
\text { products and lower induction } \\
\text { period compared to Fe-MCM-41, } \\
\text { FeOx-MCM-41 }\end{array}$ & ${ }_{65}^{65}$ \\
\hline 10 & $\begin{array}{l}{\left[\mathrm{Mn}^{\mathrm{II}}\left(\mathrm{H}_{2} \mathrm{O}\right)_{6}\right] .\left[\mathrm{Mn}^{\mathrm{II}}(\mathrm{phen})_{2}\left(\mathrm{H}_{2} \mathrm{O}\right)_{2}\right]_{2} \cdot 2 \mathrm{BTC}} \\
{\left[\mathrm{Cu}^{\mathrm{II}}\left(\mathrm{H}_{2} \mathrm{O}\right)_{6}\right] .\left[\mathrm{Mn} \mathrm{Mn}^{\mathrm{II}}(\mathrm{phen})_{2}\left(\mathrm{H}_{2} \mathrm{O}\right)_{2}\right]_{2} \cdot 2 \mathrm{BTC}} \\
{\left[\mathrm{M}^{1}\left(\mathrm{H}_{2} \mathrm{O}\right)_{6}\right] .\left[\mathrm{M}^{2}(\mathrm{phen})_{2}\left(\mathrm{H}_{2} \mathrm{O}\right)_{2}\right]_{2}(\mathrm{BTC})_{2} \text { with } \mathrm{M}^{1},} \\
\mathrm{M}^{2}: \mathrm{Co}(\mathrm{II}), \mathrm{Ni}(\mathrm{II}), \mathrm{Cu}(\mathrm{II}), \mathrm{Zn}(\mathrm{II}), \mathrm{Mn}(\mathrm{II})\end{array}$ & Phenol & $\mathrm{H}_{2} \mathrm{O}_{2}$ & $\begin{array}{l}25 \sim 35^{\circ} \mathrm{C}, 9 \sim 12 \mathrm{~h} \text { in } \\
\mathrm{EtOH}\end{array}$ & $14-21$ & Hydroquinone & $\begin{array}{l}\text { The encapsulated } \mathrm{Mn} \text { complex is } \\
\text { responsible for the activity, no } \\
\text { activity of the host }\end{array}$ & $64 a, b$ \\
\hline 11 & $\begin{array}{l}{\left[\mathrm{Co}(\text { phen })_{2}\left(\mathrm{H}_{2} \mathrm{O}\right)_{2}\right]_{2}\left[\mathrm{M}\left(\mathrm{H}_{2} \mathrm{O}\right)_{6}\right] .2 \mathrm{BTC}} \\
(\mathrm{M}=\mathrm{Co}, \mathrm{Cu}, \mathrm{Mn}) \\
{\left[\mathrm{Zn}(\text { phen })_{2}\left(\mathrm{H}_{2} \mathrm{O}\right)_{2}\right]_{2}\left[\mathrm{Mn}\left(\mathrm{H}_{2} \mathrm{O}\right)_{6}\right] .2 \mathrm{BTC}}\end{array}$ & Phenol & $\mathrm{H}_{2} \mathrm{O}_{2}$ & $\begin{array}{l}30 \sim 40^{\circ} \mathrm{C}, 8 \text { h in } \\
\mathrm{EtOH}\end{array}$ & $20.2 \sim 24.2$ & Hydroquinone & $\begin{array}{l}\text { The encapsulated complex is } \\
\text { responsible for the activity, no } \\
\text { activity of the host }\end{array}$ & $64 \mathrm{c}$ \\
\hline 12 & {$\left[\mathrm{Cu}_{2}(\mathrm{BPTC})(\mathrm{Im})_{4}\left(\mathrm{H}_{2} \mathrm{O}\right)(\mathrm{DMF})\right]_{\mathrm{n}}$} & $\begin{array}{l}\text { Phenol+functionalized } \\
\text { derivates }\end{array}$ & $\mathrm{H}_{2} \mathrm{O}_{2}$ & $\begin{array}{l}30 \sim 50^{\circ} \mathrm{C}, 2-10 \mathrm{~h} \text { in } \\
\mathrm{H}_{2} \mathrm{O} \text {, acetone or } \\
\text { EtOH }\end{array}$ & $15-62$ & Benzoquinone & $\begin{array}{l}\text { Selectivity toward single diphenols } \\
\text { and the yield of products are still } \\
\text { lower than classic catalysts }\end{array}$ & 69 \\
\hline \multirow[t]{3}{*}{13} & $\mathrm{UiO}-66-\mathrm{NH}_{2}$ & Benzyl alcohol & $\mathrm{O}_{2} 1 \mathrm{~atm}$ & $\begin{array}{l}12 \mathrm{~h}, 0{ }^{\circ} \mathrm{C} \text {, Solvent: } \\
\mathrm{CH}_{3} \mathrm{CN} / \quad \text { TFT/ }\end{array}$ & $8 \sim 13.1$ & Benzaldehyde & $\begin{array}{l}\text { polar organic media play a crucial } \\
\text { role in stabilizing the intermediate }\end{array}$ & 68 \\
\hline & & Cyclohexanol & & $\begin{array}{l}\text { Acetone/ } \mathrm{CHCl}_{3} \\
\text { /DMF; } \quad 420-450\end{array}$ & $1.6 \sim 2.8$ & Cyclohexanone & epoxides and active oxygen species & \\
\hline & & Hexyl alcohol & & $\begin{array}{ll}\mathrm{nm} & \text { light } \\
\text { irradiation } & \end{array}$ & $\begin{array}{l}0.9 \\
\text { (depend on } \\
\text { different } \\
\text { solvents) }\end{array}$ & Hexanal & & \\
\hline 14 & $0.35 \% \mathrm{Pd} / \mathrm{MIL}-101(\mathrm{Cr})$ & Cinnamyl alcohol & $\begin{array}{l}\mathrm{O}_{2} 1 \mathrm{~atm}(20 \mathrm{ml} \\
\left.\mathrm{min}^{-1}\right)\end{array}$ & $\begin{array}{l}80^{\circ} \mathrm{C}, \quad 0.5 \mathrm{~h} \text { in } \\
\text { toluene }\end{array}$ & 97 & $\begin{array}{l}\text { Cinnamyl aldehyde } \\
(99 \%)\end{array}$ & $\begin{array}{l}\text { Recyclable up to } 5 \text { times without } \\
\text { significant loss of cativity. }\end{array}$ & 70 \\
\hline
\end{tabular}


$3 \sim 15$ min,in water,

86 99

(8.3 13.4bar)
Microwave

benzaldehydes

Microwave

assisted

oxidation

Recyclable up to 3 times with over

$\left[\mathrm{Zn}_{2}\left(\mathrm{H}_{2} \mathrm{O}\right)_{4} \mathrm{Sn}^{\mathrm{N}}(\mathrm{TPyP})(\mathrm{HCOO})_{2}\right]_{3} 4 \mathrm{NO}_{3}$

1,5-Dihydroxynaphthalene

.5h, RT, solvent: >99.9

$\mathrm{CH}_{2} \mathrm{Cl}_{2} / \mathrm{MeOH}(4: 1$,

$90 \%$ of its initial activity.

the mixed solvents can prompt

hydroxynaphthalene- ${ }^{-}$photo-oxygenation smoothly

1,4-dione 


\subsection{Oxidation of thiols and sulfides}

The few MOFs that have been studied for thiol and sulfide oxidations focused on the selective production of fine chemicals (Table 3) or on ODS (Oxidative Desulfurization). Dhakshinamoorthy et al. ${ }^{21 \mathrm{~b}}$ examined the commercially available $\mathrm{Fe}(\mathrm{BTC}), \mathrm{F} 300$, for the oxidation of thiophenol. The catalyst showed moderate to high conversions at RT ( $44 \%$ of reactant conversion) and $70^{\circ} \mathrm{C}(87 \%$ of reactant conversion) in air using acetonitrile as solvent (entry 1 , Table 3), whereas, $\mathrm{Cu}_{3}(\mathrm{BTC})_{2}$ and $\mathrm{Al}_{2}(\mathrm{BDC})_{3}$ exhibit a poor catalytic performance of $28 \%$ and $4 \%$ respectively. Song et al. ${ }^{21 \mathrm{~d}}$ examined a POM@HKUST-1 material for the chemo- and shape- selective oxidation of a variety of thiols to disulfides (entry 2 Table 3). The authors observed a synergistic stabilization of both the MOF and the POM and this synergy between the two structural components was extended to the catalytic activity of the POM. Similar studies using POM@MOF or POM based MOFs for catalyzing ODS reaction have been reported in several recent papers (entry 11,12 Table 3).
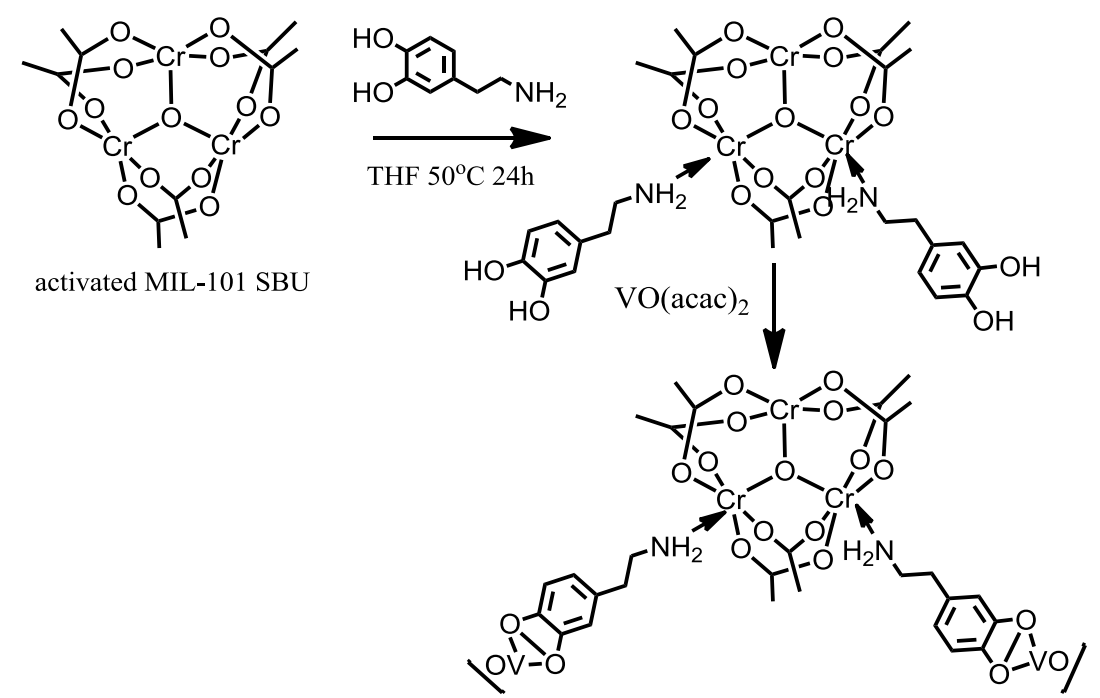

Scheme 8 : Illustration of the post-synthetic modification of MIL-101(Cr) by grafting of dopamine, then followed by by metallation of $\mathrm{VO}(\mathrm{acac})_{2}$ to create $\mathrm{V}(\mathrm{dop})-\mathrm{MIL}-101(\mathrm{Cr})$. The bracket around [VO] denotes the presence of a vanadium oxo moiety. $^{72}$

Besides the report on Cr-MIL-101 (entry 8, Table 3), or encapsulate phosphotungstic acid/ vanadium oxide in MIL-101 framework (entry 13, 15 Table 3) Nguyen and coworkers ${ }^{72}$ use Cr-MIL-101 as a model platform for the post-synthesis incorporation of catechols, which is further metallated with $\mathrm{VO}(\mathrm{acac})_{2}$ for oxidation. The postmodification procedure is illustrated in Scheme 8. The obtained V(dop)-MIL-101 has been investigated in the oxidation of thioanisole using TBHP as the oxidant. The catalyst shows catalytic activity to oxidize thioanisole to the corresponding sulfoxide and sulfone (entry 14). The catalyst can be recovered and reused up to 3 runs. Interestingly, a slight increase in the selectivity to sulfoxide is observed, which is due to the gradual conversion of the starting $\mathrm{V}^{\mathrm{IV}}$ to $\mathrm{V}^{\mathrm{V}}$.

Rare-Earth based MOFs are often used for the oxidation of sulfides. They can be divided into 2 main groups: the $\mathrm{Yb}$ and Sc based MOFs. For all these rare- earth MOFs, $\mathrm{H}_{2} \mathrm{O}_{2}$ was applied as the oxidant.

The Yb based MOF of Bernini et al. (entry 3 Table 3) has been examined for the oxidation of methylsulfanylbenzene. After an induction period, a moderate conversion of $50 \%$ in the first run was observed. The authors state that the noted induction period is due to the $\mathrm{Ln}-\mathrm{O}-\mathrm{OH}$ species that are 
formed during the first run, which are the real active species in the additional runs ${ }^{21 \mathrm{e}}$. The presence of a peroxo complex that acts as the active intermediate was suggested in their earlier report on Ln MOF based catalysts (entry 9 Table 3$)^{18 \mathrm{~b}}$. Furthermore, the same group reported much higher conversions for 2 other based Yb MOFs (entry 4 Table 3) ${ }^{14}$. Although the kinetic profile of both MOFs was different, complete conversion (>99\%) was obtained, using methylphenylsulfide as the reactant.

The latter reactant was also applied for the catalytic evaluation of the Sc based MOFs. Comparison of the Sc-terephthalate (entry 5 Table 3) with the Sc-succinate (entry 6, Table 3) shows that the reaction proceeds faster and more selectively for the terephthalate based framework under the same reaction conditions ${ }^{73}$.

The group of Monge presented in 2009 the synthesis of a novel Sc and Y-MOF, using 1,5- and 2,6naphthalenedisulfonates as organic linkers ${ }^{74}$. Although the reaction takes place at the surface of the materials, better results were obtained in comparison to their earlier reports (entries 5-6 Table 3) with conversions up to $100 \%$ in 60 minutes (entry 7 Table 3).

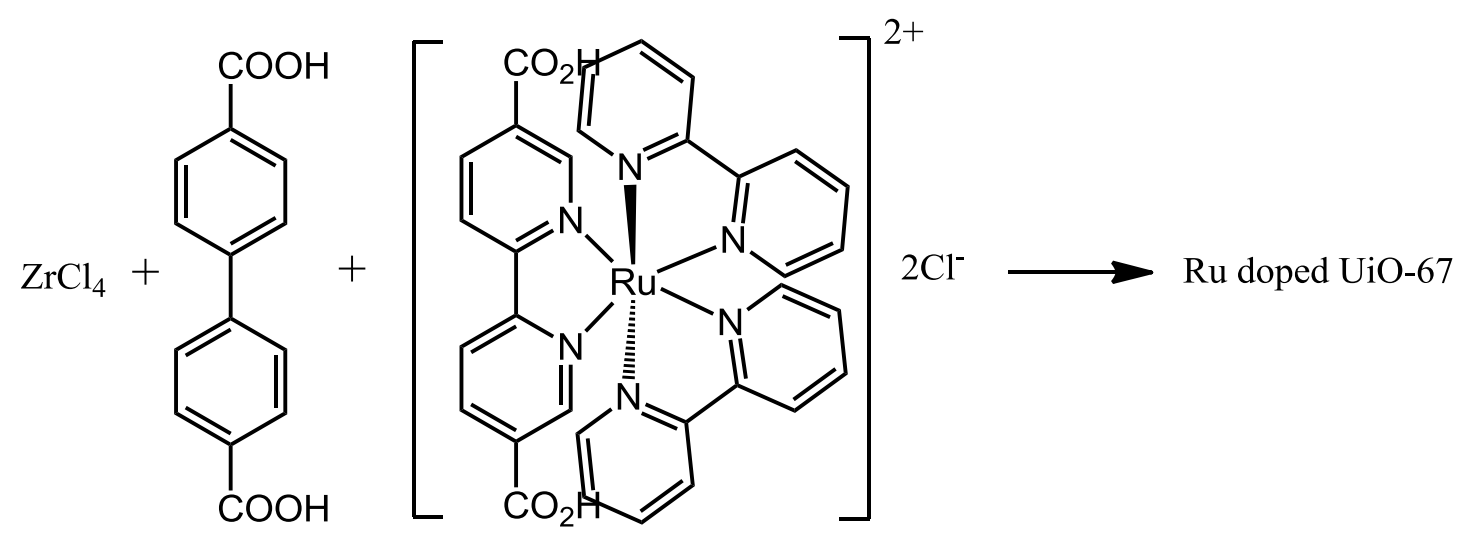

Scheme 9. Synthesis of Ru doped UiO-67(an extended framework of UiO-66, Figure 1a)

A novel photo catalytic system was developed for the aerobic oxidation of thioanisole by the Lin group in 2011 (Scheme 9) ${ }^{19 f}$ with methanol as the solvent. The Ru-doped UiO-67 successfully catalyzed the selective aerobic oxidation of thioanisole to methyl phenyl sulfoxide. No sulfone (the possible overoxidized byproduct) was detected by $1 \mathrm{H}$ NMR, demonstrating a high degree of selectivity of this reaction. 


\begin{tabular}{|c|c|c|c|c|c|c|c|c|}
\hline Entry & Catalytic MOF & Reactant & Oxidant & Reaction parameters & $\begin{array}{c}\text { Conversion } \\
(\%)\end{array}$ & Main product (selectivity) & Take home message & Ref. \\
\hline 1 & $\begin{array}{l}\mathrm{Fe}(\mathrm{BTC}) \\
\mathrm{Cu}_{3}(\mathrm{BTC})_{2} \\
\mathrm{Al}_{2}(\mathrm{BDC})_{3}\end{array}$ & Thiophenol & $\mathrm{Air} / \mathrm{O}_{2}$ & $70^{\circ} \mathrm{C}, 1 \mathrm{~h}$ in $\mathrm{CH}_{3} \mathrm{CN}$ & $\begin{array}{l}44-87 \\
28 \\
4\end{array}$ & Diphenyldisulfide & Activity: $\mathrm{Fe}>\mathrm{Cu}>\mathrm{Al}$ & $21 \mathrm{~b}$ \\
\hline 2 & {$\left[\mathrm{CuPW}_{11} \mathrm{O}_{39}\right]^{-5 @ H K U S T-1}$} & Linear and cyclic thiols & $\mathrm{Air} / \mathrm{O}_{2}$ & $\begin{array}{l}45^{\circ} \mathrm{C}, \quad 62 \text { h in } \\
\text { chlorobenzene }\end{array}$ & $27-95$ & Disulfide (99\%) & $\begin{array}{l}\text { Synergistic stabilization of both the MOF } \\
\text { and the POM }\end{array}$ & $21 d$ \\
\hline 3 & {$\left[\mathrm{Yb}\left(\mathrm{C}_{4} \mathrm{H}_{4} \mathrm{O}_{4}\right)_{1.5}\right]$} & Methylsulfanylbenzene & $\mathrm{H}_{2} \mathrm{O}_{2}$ & $60^{\circ} \mathrm{C}, 6 \mathrm{~h}$ in $\mathrm{CH}_{3} \mathrm{CN}$ & 50 & $\begin{array}{l}\text { Methyl phenyl sulfoxide } \\
(92 \%)\end{array}$ & $\begin{array}{l}\text { In first run: induction period due to } \\
\text { formation of the active species }\end{array}$ & $21 e$ \\
\hline 4 & $\begin{array}{l}{\left[\mathrm{Yb}_{4}(\mathrm{OH})_{10}\left(\mathrm{H}_{2} \mathrm{O}\right)_{4}\right][2,6-\mathrm{AQDS}]} \\
{\left[\mathrm{Yb}(\mathrm{OH})(2,6-\mathrm{AQDS})\left(\mathrm{H}_{2} \mathrm{O}\right)\right]}\end{array}$ & Methylphenylsulfide & $\mathrm{H}_{2} \mathrm{O}_{2}$ & $\begin{array}{l}60^{\circ} \mathrm{C}, \quad 30 \text { min in } \\
\mathrm{CH}_{3} \mathrm{CN}\end{array}$ & $>99$ & $\begin{array}{l}\text { Methyl phenyl sulfoxide } \\
(>99 \%)\end{array}$ & $\begin{array}{l}\text { Higher charge density yields in poorer } \\
\text { activity }\end{array}$ & 14 \\
\hline 5 & {$\left[\mathrm{Sc}_{2}\left(\mathrm{C}_{8} \mathrm{H}_{4} \mathrm{O}_{3}\right)_{3}\right]$} & $\begin{array}{l}\text { Methylphenylsulfide and } \\
\left(2^{-}\right. \\
\text {ethylbutyl)phenylsulfide }\end{array}$ & $\mathrm{H}_{2} \mathrm{O}_{2}$ & $50^{\circ} \mathrm{C}, 4 \mathrm{~h}$ in $\mathrm{CH}_{3} \mathrm{CN}$ & $\sim 90$ & Sulfoxide (85\%) & $\begin{array}{l}\text { No loss in activity or selectivity for at } \\
\text { least } 4 \text { runs }\end{array}$ & $73 a$ \\
\hline 6 & $\begin{array}{l}{\left[\mathrm{Sc}_{2}\left(\mathrm{C}_{4} \mathrm{H}_{4} \mathrm{O}_{4}\right)_{2.5}(\mathrm{OH})\right]} \\
{\left[\mathrm{Y}_{2}\left(\mathrm{C}_{4} \mathrm{H}_{4} \mathrm{O}_{4}\right)_{3}\left(\mathrm{H}_{2} \mathrm{O}\right)_{2}\right] \cdot \mathrm{H}_{2} \mathrm{O}} \\
{\left[\mathrm{La}_{2}\left(\mathrm{C}_{4} \mathrm{H}_{4} \mathrm{O}_{4}\right)_{3}\left(\mathrm{H}_{2} \mathrm{O}\right)_{2}\right] \cdot \mathrm{H}_{2} \mathrm{O}}\end{array}$ & $\begin{array}{l}\text { Methylphenylsulfide and } \\
(2- \\
\text { ethylbutyl)phenylsulfide }\end{array}$ & $\mathrm{H}_{2} \mathrm{O}_{2}$ & $\begin{array}{l}40^{\circ} \mathrm{C}, 6 \mathrm{~h} \text { in } \mathrm{CH}_{3} \mathrm{CN} \\
\mathrm{H} 2 \mathrm{O} 2 / \text { substrate: } 2.5\end{array}$ & $\begin{array}{l}\sim 85 \\
>99 \text { and } 95 \\
>99 \text { and } 86\end{array}$ & $\begin{array}{l}\text { Sulfoxide }(90-99 \%) \\
\text { Sulfoxide }(90-95 \%) \\
\text { Sulfoxide }(90-95 \%)\end{array}$ & $\begin{array}{l}\text { Every MOF: total conversion in } 60 \mathrm{~min} \text {. to } \\
\text { the sulfoxide }\end{array}$ & $73 \mathrm{~b}$ \\
\hline 7 & $\begin{array}{l}{\left[\mathrm{Sc}_{2}(\mathrm{nds})(\mathrm{OH})_{4}\right]_{\mathrm{n}}} \\
{\left[\mathrm{Y}\left(1,5 \text {-nds) }(\mathrm{OH})\left(\mathrm{H}_{2} \mathrm{O}\right)\right]_{\mathrm{n}}\right.}\end{array}$ & Methylphenylsulfide & $\mathrm{H}_{2} \mathrm{O}_{2}$ & $60^{\circ} \mathrm{C}, 1 \mathrm{~h}$ in $\mathrm{CH}_{3} \mathrm{CN}$ & $>99$ & $\begin{array}{l}\text { Methyl phenyl sulfoxide } \\
(>99 \%)\end{array}$ & $\begin{array}{l}\text { The catalysts could be reused at least four } \\
\text { times with neither loss of activity nor } \\
\text { selectivity }\end{array}$ & 74 \\
\hline 8 & Cr-MIL-101 & $\begin{array}{l}\text { Benzenethiol, } \\
\text { diphenylsulfide and } \\
\text { isopropyl phenylsulfide }\end{array}$ & $\mathrm{H}_{2} \mathrm{O}_{2}$ & $\begin{array}{l}25^{\circ} \mathrm{C}, 12 \mathrm{~h} \text { in } \mathrm{CH}_{3} \mathrm{CN} \text {, } \\
\text { ratio } \mathrm{H}_{2} \mathrm{O}_{2} / \text { benzyl } \\
\text { phenyl sulfide:2 }\end{array}$ & $88-99$ & Sulfoxide (>99\%) & $\begin{array}{l}\text { Reactants with electron-releasing groups } \\
\text { enhance the activity }\end{array}$ & 75 \\
\hline 9 & $\begin{array}{l}{\left[\mathrm{Ln}_{2}\left(\mathrm{C}_{17} \mathrm{H}_{8} \mathrm{~F}_{6} \mathrm{O}_{4}\right)_{3}\right] \text { with } \mathrm{Ln}=\mathrm{Yb}} \\
\mathrm{Er}, \mathrm{Gd}, \mathrm{Sm}, \mathrm{Nd}, \mathrm{La}\end{array}$ & Methylphenylsulfide & $\mathrm{H}_{2} \mathrm{O}_{2}$ & $\begin{array}{l}\mathrm{RT}, 3 \sim 5 \mathrm{~h} \text { in } \mathrm{CH}_{3} \mathrm{CN} \\
\mathrm{H} 2 \mathrm{O} 2 / \text { substrate: } 3\end{array}$ & $78-92$ & Sulfoxide & Presence of peroxo complex: active species & $18 b$ \\
\hline 10 & {$\left[\mathrm{Zn}_{2}(\mathrm{bdc})(\mathrm{L}-\mathrm{lac})(\mathrm{dmf})\right] . \mathrm{DMF}$} & Tetrahydrothiopyran & $\mathrm{H}_{2} \mathrm{O}_{2}$ & $\begin{array}{l}\mathrm{RT}, \quad 24 \mathrm{~h} \text { in } \\
\mathrm{CH}_{3} \mathrm{CN} / \mathrm{CH}_{2} \mathrm{Cl}_{2}, \text { ratio } \\
\text { substrate } / \mathrm{H}_{2} \mathrm{O}_{2}=1: 1\end{array}$ & 72 & Sulfone $(98 \%)$ & $\begin{array}{l}\text { No sulfone formation in the initial period } \\
\text { of reaction }\end{array}$ & 76 \\
\hline 11 & $\mathrm{~Tb}\left(\mathrm{PW}_{11}\right)_{2} @ \mathrm{MIL}-101(\mathrm{Cr})$ & $\begin{array}{l}\text { Dibenzothiophene, } \\
\text { 1-benzothiophene } \\
4,6^{-} \\
\text {dimethyldibenzothiophene }\end{array}$ & $\begin{array}{l}\text { Air } 1 \mathrm{~atm} \\
\text { (initiated } \\
\text { by } 75 \mu \mathrm{l} \\
\mathrm{H}_{2} \mathrm{O}_{2} \text { ) }\end{array}$ & $\begin{array}{l}50{ }^{\circ} \mathrm{C}, 5 \mathrm{~h} \text {, biphase } \\
\text { system (equal volume } \\
\text { of oil+ MeCN) }\end{array}$ & 100 & 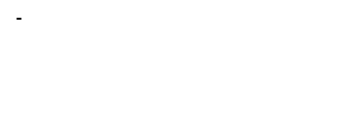 & $\begin{array}{l}\text { POM@MOF catalysed ODS using biphase } \\
\text { system complete desulfurization } \\
\text { achieved in } 5 \mathrm{~h} .\end{array}$ & 77 \\
\hline 12 & $\begin{array}{l}\left.\mathrm{H}\left[\mathrm{LnH}_{2} \mathrm{O}\right)_{4}\right]_{2}\left[\mathrm{MnV}_{13} \mathrm{O}_{38}\right] \quad(\mathrm{Ln}= \\
\mathrm{La} \text { or } \mathrm{Ce})\end{array}$ & Variable sulphide & TBHP & $\begin{array}{l}50^{\circ} \mathrm{C}, 3 \sim 6 \mathrm{~h} \text { in } \mathrm{CH}_{2} \mathrm{Cl}_{2} \\
\text { TBHP: substrate }=5: 1\end{array}$ & $98.8 \sim 99.5$ & Corresponding sulfone & $\begin{array}{l}{[\mathrm{MnV} 13 \mathrm{O} 38]^{7} \text { is the redox catalytic active }} \\
\text { center for ODC process, it is } \\
\text { heterogenized into a POM based porous } \\
\text { framework }\end{array}$ & 78 \\
\hline 13 & PTA-MIL-101(Cr) & $\begin{array}{l}\text { Benzothiophene, } \\
\text { dibenzothiophene or } 4,6^{-} \\
\text {dimethyldibenzothiophene }\end{array}$ & $\mathrm{H}_{2} \mathrm{O}_{2}$ & $\begin{array}{l}50{ }^{\circ} \mathrm{C}, 1-5 \mathrm{~h}, \text { in } \mathrm{n}^{-} \\
\text {heptane } \\
\text { Oxidant/substrate }=50\end{array}$ & $72 \sim 91$ & 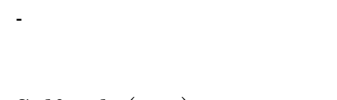 & $\begin{array}{l}\text { The sulphide oxidation process are } \\
\text { contributed from both PTA and } \mathrm{Cr}^{3+} \text { in } \\
\text { the presence of large excess of } \mathrm{H} 2 \mathrm{O} 2\end{array}$ & 79 \\
\hline 14 & V(dop)-MIL-101(Cr) & Thioanisole & $\begin{array}{l}\text { TBHP in } \\
\text { nonane }\end{array}$ & $\begin{array}{l}\mathrm{RT}, \quad 8 \mathrm{~h} \text {, in } \mathrm{CH}_{2} \mathrm{Cl}_{2} . \\
\text { oxidant : substrate: } \\
\text { catalyst }=100: 100: 1\end{array}$ & 83 & $\begin{array}{l}\text { Sulfoxide }(69 \%) \\
\text { Sulfone }(31 \%)\end{array}$ & $\begin{array}{l}\text { The catalytic activity is attributed to the } \\
\text { vanadium actecholate species. }\end{array}$ & 72 \\
\hline 15 & $4.2 \% \mathrm{~V} @ \mathrm{MIL}-101(\mathrm{Cr})$ & Sulphide & $\mathrm{H}_{2} \mathrm{O}_{2}$ & $\begin{array}{l}\mathrm{RT}, 0.5 \sim 3 \mathrm{~h}, \quad \mathrm{H}_{2} \mathrm{O}_{2}: \\
\text { substrate=8:1 } \\
\text { Solvent: EtOH or } \\
\mathrm{CH}_{3} \mathrm{CN}\end{array}$ & $\begin{array}{l}87 \sim 98 \text { (in } \\
\text { EtOH) } \\
92 \sim 98 \\
\left.\mathrm{CH}_{3} \mathrm{CN}\right)\end{array}$ & $\begin{array}{l}\text { sulfoxide(in } \mathrm{EtOH} \text { ) } \\
\text { sulfone (in } \mathrm{CH} 3 \mathrm{CN} \text { ) }\end{array}$ & $\begin{array}{l}\text { Changing solvent from } \mathrm{EtOH} \text { to } \mathrm{CH}_{3} \mathrm{CN} \\
\text { results in different product formation. }\end{array}$ & 80 \\
\hline 16 & $\begin{array}{l}{\left[\mathrm{Zn}_{2}\left(\mathrm{H}_{2} \mathrm{O}\right)_{4} \mathrm{Sn}^{\mathrm{IV}}(\mathrm{TPyP})(\mathrm{HCOO})_{2}\right]} \\
{ }_{3} \mathrm{NO}_{3}\end{array}$ & Various sulfides & $\mathrm{O}_{2}$ & $\begin{array}{l}12 \mathrm{~h}, \quad \mathrm{RT}, \quad \text { solvent: } \\
\mathrm{CH}_{2} \mathrm{Cl}_{2} / \mathrm{MeOH}(4: 1,\end{array}$ & $93 \sim>99.9$ & Corresponding sulfoxides & $\begin{array}{l}\text { Sn porphyrin based MOF shows better } \\
\text { selectivity to sulfoxide than homogeneous }\end{array}$ & 67 \\
\hline
\end{tabular}


v/v), 350WXe lamp
irradiation

irradiation
$\mathrm{RT}, 22 \mathrm{~h}$,

Thioanisole
$\mathrm{MeOH}$

Sn-porphyrin complex, the latter let the

sufidide partially converted to sulphone.

The conversion after $22 \mathrm{~h}$ is comparable to

that of the corresponding homogeneous

catalytic system

Table 3. Overview of the MOFs studied for the oxidation of thiols and/or sulfides 


\subsection{Oxidation of cycloalkenes and linear alkenes}

Ethylene oxide is produced aerobically using a silver catalyst ${ }^{81}$, but a similar efficient process for the aerobic epoxidation of other (cyclo)alkenes has not been yet implemented. Nice progress in this field has been achieved by using supported gold catalysts ${ }^{82}$. In general, selective epoxidation of alkenes using molecular oxygen instead of peracids or peroxides still remains a challenge in catalysis and green chemistry. Next to epoxidations, allylic oxidations are also relevant in the synthesis of fine chemicals. For asymmetric or chiral epoxidations, transition metal complexes containing redox active transition metals like $\mathrm{Cu}, \mathrm{Co}, \mathrm{Mn}$ and $\mathrm{Fe}$ with Schiff-base ligands are important homogenous catalysts which can oxidize alkenes with oxygen. The most efficient is the Mn-salen complex, also known as the Jacobsen catalyst ${ }^{83}$. The use of MOFs in chiral and asymmetric oxidations will be discussed in the next paragraph.

Evidently, catalytic studies on MOFs for the epoxidation of the $\mathrm{C}=\mathrm{C}$ bond have received considerable attention as can be inferred from Table 4. Commonly investigated (non prochiral) reactants are cyclohexene, cyclooctene and styrene. During the oxidation of cyclohexene, many products can be formed, as can be seen from Scheme 10.

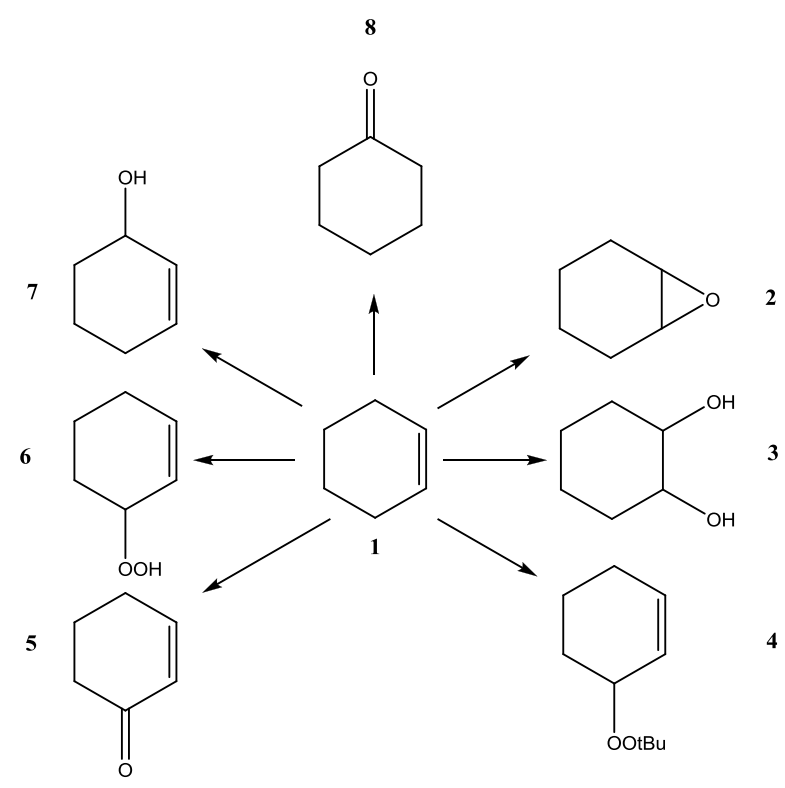

Scheme 10. Oxidation of cyclohexene 1 toward the products: cyclohexene oxide $\mathbf{2}$ cyclohexane-1,2-diol 3, tert-butyl-2cyclohexenyl-1-peroxide 4, 2-cyclohexene-1-one 5, cyclohexene hydroperoxide 6, 2-cyclohexen-1-ol 7 and cyclohexanone 8.

From Table 4, principally 5 classes of MOFs, studied in the oxidation of alkenes, can be distinguished. More specifically, Cu-, Co-, rare-earth, V- and "linker-modified" MOFs. Each of these classes will now be discussed in more detail. There have been studies using other MOFs as well. Worth mentioning is the study of the group of Gascon and Kapteijn ${ }^{84}$. The MIL-101(Cr) was immobilized on monoliths using seeding techniques followed by a secondary growth. A monolithic stirrer reactor has been used to explore reactivation procedures of MIL-101 in the selective oxidation of tetralin. However we will focus in the Table and discussion on the 5 classes mentioned above. 
Table 4. Overview of MOFs examined for the oxidation of cyclic and/or linear alkenes. 


\begin{tabular}{|c|c|c|c|c|c|c|c|c|}
\hline Entry & Catalytic MOF & Reactant & Oxidant & $\begin{array}{l}\text { Reaction } \\
\text { parameters }\end{array}$ & $\begin{array}{l}\text { Conversion } \\
(\%)\end{array}$ & Main product (selectivity) & Take home message & Ref. \\
\hline 1 & {$\left[\mathrm{Cu}(\mathrm{bpy})\left(\mathrm{H}_{2} \mathrm{O}\right)_{2}\left(\mathrm{BF}_{4}\right)_{2}(\mathrm{bpy})\right]$} & Cyclohexene & $\mathrm{O}_{2}$ & $\begin{array}{l}45^{\circ} \mathrm{C}, \quad 15 \quad \mathrm{~h}, \quad \text { no } \\
\text { solvent }\end{array}$ & 8 & $\begin{array}{l}\text { Cyclohexene hydroperoxide } \\
(90 \%)\end{array}$ & $\begin{array}{l}\text { No solvent, high selectivity }(90 \%) \text { to } \\
\text { cyclohexene hydroperoxide }\end{array}$ & 85 \\
\hline 2 & $\begin{array}{l}\left\{\left[\mathrm{Cu}(\mathrm{Pht})(\mathrm{Im})_{2}\right] \cdot 1.5 \mathrm{H}_{2} \mathrm{O}\right\}_{\mathrm{n}} \\
{\left[\mathrm{Co}(\mathrm{Pht})(\mathrm{Im})_{2}\right]_{\mathrm{n}}}\end{array}$ & Cyclohexene & $\mathrm{H}_{2} \mathrm{O}_{2}$ & $\mathrm{RT}, 1 \mathrm{~h}$ in acetone & $\begin{array}{l}75.2 \\
40.6\end{array}$ & $\begin{array}{l}\text { 2-cyclohexen-1-one }(40.6- \\
75.2 \%)\end{array}$ & Yield of ketone: $\mathrm{Cu}-\mathrm{MOF}>\mathrm{Co}-\mathrm{MOF}$ & 86 \\
\hline 3 & {$\left[\mathrm{Cu}\left(\mathrm{H}_{2} \text { btec }\right)(\text { bipy })\right]_{\infty}$} & $\begin{array}{l}\text { Cyclohexene/ } \\
\text { styrene }\end{array}$ & TBHP & $\begin{array}{l}75^{\circ} \mathrm{C}, 24 \mathrm{~h} \text { in } 1,2^{-} \\
\text {dichloroethane in } \\
\mathrm{N}_{2} \text { atmosphere }\end{array}$ & $61.8 / 26.9$ & Epoxide $(68.4 / 70.2 \%)$ & $\begin{array}{l}\text { Cyclohexene: higher conversion but } \\
\text { lower selectivity, styrene: lower } \\
\text { conversions but higher selectivity }\end{array}$ & ${ }^{87}, 88$ \\
\hline 4 & $\begin{array}{l}{\left[\mathrm{Cu}_{2}(\mathrm{OH})(\mathrm{BTC})\left(\mathrm{H}_{2} \mathrm{O}\right)\right]_{\mathrm{n}} \cdot 2 \mathrm{nH}_{2}} \\
\mathrm{O} \\
{\left[\mathrm{Co}_{2}(\mathrm{DOBDC})\left(\mathrm{H}_{2} \mathrm{O}\right)_{2}\right] .8 \mathrm{H}_{2} \mathrm{O}}\end{array}$ & Cyclohexene & $\mathrm{O}_{2}$ & $80^{\circ} \mathrm{C}, 20 \mathrm{~h}$ & $\begin{array}{l}20.8 \\
32.8\end{array}$ & $\begin{array}{l}\text { 2-cyclohexen-1-ol } \\
\text { 2-cyclohexen-1-one }\end{array}$ & Solvent free catalysis & 89 \\
\hline 5 & {$\left[\mathrm{Co} \mathrm{II}^{\mathrm{II}}(\mathrm{bpb})\right] .3 \mathrm{DMF}$} & Cyclohexene & TBHP & $\begin{array}{ll}80^{\circ} \mathrm{C}, & 12 \mathrm{~h} \\
\mathrm{CH}_{2} \mathrm{Cl}_{2} & \text { in }\end{array}$ & 62 & $\begin{array}{l}\text { Tert-butyl-2- } \\
\text { cyclohexenyl-1-peroxide }(83 \%)\end{array}$ & $\begin{array}{l}83 \% \text { selectivity toward tert-butyl-2- } \\
\text { cyclohexenyl-1-peroxide }\end{array}$ & 90 \\
\hline 6 & {$\left[\mathrm{Co}_{4}{ }_{4} \mathrm{O}(\mathrm{bdpb})_{3}\right]=\mathrm{MFU}-1$} & Cyclohexene & TBHP & $\begin{array}{l}70^{\circ} \mathrm{C}, 22 \mathrm{~h} \text {, ratio } \\
\text { substrate/TBHP:2 }\end{array}$ & 27.5 & $\begin{array}{l}\text { Tert-butyl-2-cyclohexenyl-1- } \\
\text { peroxide }(66 \%)\end{array}$ & $\begin{array}{l}\text { Reaction in the pores, high selectivity } \\
\text { to allylic substitution product }(66 \%)\end{array}$ & 11 \\
\hline 7 & $\begin{array}{l}\text { MFU-2 } \\
\text { NHPI@MFU-1 }\end{array}$ & Cyclohexene & $\begin{array}{l}\text { TBHP } \\
\text { Air }\end{array}$ & $\begin{array}{l}70^{\circ} \mathrm{C}, 22 \mathrm{~h}, \quad \text { ratio } \\
\text { substrate/TBHP:2 } \\
35^{\circ} \mathrm{C}, \quad 24 \mathrm{~h} \quad \text { in } \\
\mathrm{CH}_{3} \mathrm{CN}\end{array}$ & $\begin{array}{l}16 \\
35\end{array}$ & $\begin{array}{l}\text { Tert-butyl-2-cyclohexenyl-1- } \\
\text { peroxide } \\
\text { Cyclohexene hydroperoxide }\end{array}$ & $\begin{array}{l}\text { high selectivities toward the allylic } \\
\text { substitution product, MFU-2: } \\
\text { leaching observed }\end{array}$ & 91 \\
\hline 9 & Co-STA12 & (E) stilbene & $\mathrm{O}_{2}$ & $\begin{array}{l}100{ }^{\circ} \mathrm{C} \text {, in } \mathrm{DMF} \\
\text { for } 12 \mathrm{~h} \text {, } \mathrm{O}_{2} \text { flow: } \\
50 \mathrm{~mL} / \mathrm{min}\end{array}$ & 95 & Trans-stilbene oxide $(90 \%)$ & $\begin{array}{l}\text { Induction period, catalysis occurs } \\
\text { mainly heterogeneous }\end{array}$ & $9_{3}$ \\
\hline 10 & $\begin{array}{l}\mathrm{Ln}_{\mathrm{n}}\left(\mathrm{N}_{3}\right)(\mathrm{nic})_{\mathrm{n}}(\mathrm{OH})_{1.5 \mathrm{n}}\left(\mathrm{Hnic}_{0.5}\right. \\
\mathrm{n}=2 \\
\mathrm{Ln}=\mathrm{Y}, \mathrm{Gd}, \mathrm{Sm}\end{array}$ & $\begin{array}{l}\text { Cyclooctene/ } \\
\text { styrene/ substituted } \\
\text { styrene derivates } \\
\text { and linear alkenes }\end{array}$ & TBHP & $\begin{array}{l}68 \sim 70^{\circ} \mathrm{C}, 24 \mathrm{~h} \text { in } \\
\mathrm{CH}_{3} \mathrm{CN}\end{array}$ & $40-99$ & $\begin{array}{l}\text { Cyclooctene oxide ( }>99 \%) / \\
\text { Styrene oxide / Epoxide }\end{array}$ & Activity: MOF> rare- earth oxides & 94 \\
\hline 11 & $\begin{array}{l}{\left[\mathrm{Nd}(\mathrm{HCOO})_{3}\right]_{n}} \\
{\left[\mathrm{Pr}(\mathrm{HCOO})_{3}\right]_{n}}\end{array}$ & $\begin{array}{l}\text { Cyclopentene/ } \\
\text { Cyclooctene/ } \\
\text { Styrene/ substituted } \\
\text { styrene derivates } \\
\text { and linear alkenes }\end{array}$ & TBHP & $\begin{array}{l}65 \sim 68^{\circ} \mathrm{C}, 24 \mathrm{~h} \text { in } \\
\mathrm{CH}_{3} \mathrm{CN}\end{array}$ & $38-99$ & $\begin{array}{l}\text { Cyclopentene oxide }(>99 \%) / \\
\text { styrene oxide/ epoxide }\end{array}$ & $\begin{array}{l}\text { Selectivity and conversion depends on } \\
\text { steric hindrance of reactant }\end{array}$ & $9_{5}$ \\
\hline 12 & MIL-47 & Cyclohexene & $\begin{array}{l}\text { TBHP in } \\
\text { water } \\
\text { /TBHP in } \\
\text { decane }\end{array}$ & $\begin{array}{l}50^{\circ} \mathrm{C}, \text { molar ratio } \\
\text { cyclohexene/oxida } \\
\mathrm{nt}=1 / 2, \text {, solvent: } \\
\text { chloroform, inert } \\
\text { atmosphere }\end{array}$ & $55 / 30$ & $\begin{array}{l}\text { Tert-butyl-2-cyclohexenyl-1- } \\
\text { peroxide/ cyclohexene oxide }\end{array}$ & $\begin{array}{l}\text { Stability and selectivity toward the } \\
\text { epoxide increased by using TBHP in } \\
\text { decane as oxidant }\end{array}$ & ${ }_{96}$ \\
\hline 14 & $\mathrm{TiO}(\mathrm{acac})_{2} @ \mathrm{NH}_{2}-\mathrm{MIL}-47$ & Cyclohexene & $\begin{array}{l}\mathrm{O}_{2}+\text { cyclo } \\
\text { hexaneca }\end{array}$ & $\begin{array}{ll}40^{\circ} \mathrm{C}, & \mathrm{O}_{2} \text { flow: } \\
7 \mathrm{~mL} / \mathrm{min}, & 6 \mathrm{~h} \text { in } \\
\end{array}$ & 25 & Cyclohexene oxide & $\begin{array}{l}\text { Enhanced stability and activity in } \\
\text { comparison to the non-modified }\end{array}$ & 98 \\
\hline
\end{tabular}




\begin{tabular}{|c|c|c|c|c|c|c|c|c|}
\hline & & & $\begin{array}{l}\text { rboxalde } \\
\text { hyde }\end{array}$ & $\mathrm{CH}_{3} \mathrm{CN}$ & & & material & \\
\hline \multirow[t]{2}{*}{15} & $\begin{array}{l}\text { Co-POM@Cr-MIL-101 } \\
\text { Ti-POM@Cr-MIL-101 }\end{array}$ & $\begin{array}{l}\text { a-pinene/ } \\
\text { Cyclohexene/ }\end{array}$ & $\begin{array}{l}\mathrm{O}_{2} \\
\mathrm{H}_{2} \mathrm{O}_{2}\end{array}$ & $\begin{array}{l}50^{\circ} \mathrm{C}, \quad 2 \sim 5 \mathrm{~h} \quad \text { in } \\
\mathrm{CH}_{3} \mathrm{CN} / 70^{\circ} \mathrm{C}, 6 \mathrm{~h}\end{array}$ & $\begin{array}{l}40-45 / \\
39 /\end{array}$ & $\begin{array}{l}\text { Verbenol }(29 \%) \\
\text { Verbenol }(32 \%) /\end{array}$ & \multirow[t]{2}{*}{$\begin{array}{l}\mathrm{O}_{2}: \text { catalyst is stable, } \mathrm{H}_{2} \mathrm{O}_{2}: \mathrm{MIL}-101 \\
\text { matrix is destroyed }\end{array}$} & \multirow[t]{2}{*}{$9 g$} \\
\hline & Ti-POM@Cr-MIL-101 & Caryophyllene & $\mathrm{H}_{2} \mathrm{O}_{2}$ & $\begin{array}{l}\text { in } \mathrm{CH}_{3} \mathrm{CN} / 50^{\circ} \mathrm{C} \\
4 \mathrm{~h} \text { in } \mathrm{CH}_{3} \mathrm{CN}\end{array}$ & 88 & Ketone+alcohol/ epoxide $(>99 \%)$ & & \\
\hline 16 & $\begin{array}{l}5 \% \mathrm{PW}_{4} / \mathrm{Cr}-\mathrm{MIL}-101 \\
5 \% \mathrm{PW}_{12} / \mathrm{Cr}-\mathrm{MIL}-101\end{array}$ & $\begin{array}{l}\text { Cyclohexene } \\
\text { Cyclohexene/ other } \\
\text { cyclic alkenes }\end{array}$ & $\mathrm{H}_{2} \mathrm{O}_{2}$ & $\begin{array}{l}50^{\circ} \mathrm{C}, 3 \sim 5 \mathrm{~h} \\
\mathrm{CH}_{3} \mathrm{CN}\end{array}$ & $\begin{array}{l}76 \\
72 / 30-76\end{array}$ & $\begin{array}{l}\text { Cyclohexene oxide }(74 \%) \\
\text { Cyclohexene oxide }(76 \%) \\
\text { Epoxide }(71-99 \%)\end{array}$ & $\begin{array}{l}\text { Good selectivity toward epoxide }\left(70^{-}\right. \\
80 \%) \text { : depends on POM loading }\end{array}$ & 100 \\
\hline 17 & PTA@Cr-MIL-101 & Caryophyllene & $\mathrm{H}_{2} \mathrm{O}_{2}$ & $\begin{array}{l}55^{\circ} \mathrm{C}, \quad 5 \text { min in } \\
\mathrm{CH}_{3} \mathrm{CN}, \\
\text { microwave power: } \\
\text { 300mW }\end{array}$ & $>90$ & Caryophyllene oxide & $\begin{array}{l}\text { Utilization of microwave heating during } \\
\text { the catalytic tests }\end{array}$ & 101 \\
\hline 18 & $\begin{array}{l}\text { Fe-MIL-101 } \\
\text { Cr-MIL-101 }\end{array}$ & $\begin{array}{l}\text { Cyclohexene/Cycloh } \\
\text { exane }\end{array}$ & $\begin{array}{l}\mathrm{O}_{2} \\
\text { TBHP+a } \\
\text { ir }\end{array}$ & $\begin{array}{l}60^{\circ} \mathrm{C}, \quad 10 \sim 16 \mathrm{~h} / \\
70^{\circ} \mathrm{C}, 8 \mathrm{~h}\end{array}$ & $\begin{array}{l}44 / 24 \\
16 / 36\end{array}$ & $\begin{array}{l}\text { Cyclohexenyl hydroperoxide } \\
(46 \%) / \text { Cyclohexyl } \\
\text { hydroperoxide }(46 \%) \\
\text { 2-cyclohexene-1-one }(56 \%) / \\
\text { Cyclohexanone }(75 \%)\end{array}$ & $\begin{array}{l}\text { Fe-MIL-101 is less stable in the } \\
\text { oxidative medium than Cr-MIL-101 } \\
\text { and product distribution depends on } \\
\text { the nature of the active metal }\end{array}$ & 102 \\
\hline 19 & NHPI@FeBTC & $\begin{array}{l}\text { Styrene/ } \\
\text { Substituted styrene } \\
\text { derivates }\end{array}$ & $\mathrm{O}_{2}$ & $\begin{array}{l}100^{\circ} \mathrm{C}, \quad 1 \sim 10 \mathrm{~h} \text { in } \\
\text { toluene }\end{array}$ & $10 / 12-60$ & $\begin{array}{l}\text { Benzaldehyde }(60 \%) / \text { Aldehyde } \\
(63-75 \%)\end{array}$ & $\begin{array}{l}\text { Conversion increased by electron } \\
\text { donating substituents }\end{array}$ & 103 \\
\hline 20 & VO(acac) $)_{2} @$ IRMOF-3 & Cyclohexene & TBHP & $60^{\circ} \mathrm{C}, 72 \mathrm{~h}$ in $\mathrm{THF}$ & 40 & - & Low catalytic activity and stability & 104 \\
\hline 21 & $\mathrm{Mn}(\mathrm{acac})_{2} @ \mathrm{IRMOF}-3$ & $\begin{array}{l}\text { Cyclohexene/ } \\
\text { Cyclooctene/ } \\
\text { Styrene }\end{array}$ & $\begin{array}{l}\mathrm{O}_{2}+\text { aldeh } \\
\text { yde }\end{array}$ & $\begin{array}{l}40^{\circ} \mathrm{C}, \quad 6 \quad \mathrm{~h} \quad \text { in } \\
\text { toluene, ratio } \\
\text { substrate/aldehyd } \\
=1 / 2\end{array}$ & $52.3-67.5$ & Epoxide (92/ 95.8/ 80.7 \%) & $\begin{array}{l}\text { High selectivities toward the epoxide } \\
(>80 \%) \text { and good stability }\end{array}$ & 105 \\
\hline 22 & Mn(III)-porphyrin MOF & Styrene, stilbene & $\begin{array}{l}2 \text {-(tert- } \\
\text { butylsulf } \\
\text { onyl) } \\
\text { iodosylbe } \\
\text { nzene }\end{array}$ & $\mathrm{RT}, 3 \mathrm{~h}$ in $\mathrm{CH}_{2} \mathrm{Cl}_{2}$ & - & - & $\begin{array}{l}\text { Improvement of the catalytic activity } \\
\text { and lifetime. Only the TON numbers } \\
\text { are reported }\end{array}$ & 106 \\
\hline 23 & Mn (III)-porphyrin Zn-MOF & Styrene & $\begin{array}{l}2 \text {-(tert- } \\
\text { butylsulf } \\
\text { onyl)iodo } \\
\text { sylbenze } \\
\text { ne }\end{array}$ & In $\mathrm{CH}_{3} \mathrm{CN}$ & $\cdot$ & Styrene oxide & $\begin{array}{l}\text { ZnMn-RPM MOF showed a TON of } \\
2150 \text { and stopped only because of } \\
\text { depletion of oxidant }\end{array}$ & 107 \\
\hline 24 & $\begin{array}{l}{\left[\mathrm{Co}_{2}\left(\mathrm{\mu}_{2}-\mathrm{H}_{2} \mathrm{O}\right)\left(\mathrm{H}_{2} \mathrm{O}\right)_{4}\right]\left(\mathrm{Co}^{-}\right.} \\
\mathrm{dcdbp}) .\left(\mathrm{H}_{2} \mathrm{O}\right)_{6} \cdot\left(\mathrm{C}_{2} \mathrm{H}_{5} \mathrm{OH}\right)_{12} .(\mathrm{D} \\
\mathrm{MF})_{12}\end{array}$ & Stilbene & TBHP & $\begin{array}{l}60^{\circ} \mathrm{C}, \quad 24 \quad \mathrm{~h} \text { in } \\
\mathrm{CH}_{3} \mathrm{CN}\end{array}$ & 95.7 & Stilbene oxide (87.1\%) & $\begin{array}{l}\text { Catalyst could be reused for } 8 \text { runs } \\
\text { without significant drop in activity }\end{array}$ & 108 \\
\hline 25 & $\begin{array}{l}{\left[\mathrm{Ni}_{2}(\mathrm{dhtp})\left(\mathrm{H}_{2} \mathrm{O}\right)_{2}\right] .8 \mathrm{H}_{2} \mathrm{O}=\mathrm{Ni}^{-}} \\
\text {CPO-27 }\end{array}$ & Cyclohexene & $\mathrm{H}_{2} \mathrm{O}_{2}$ & $\begin{array}{l}60^{\circ} \mathrm{C}, \quad 8 \text { h in } \\
\mathrm{CH}_{3} \mathrm{CN}\end{array}$ & 75.4 & Cyclohexene oxide (39.7\%) & Only heterogeneous catalysis at RT & 109 \\
\hline 26 & {$\left[\mathrm{Mn}(\mu \text {-terph })\left(\mathrm{H}_{2} \mathrm{O}\right)_{2}\right]_{\mathrm{n}}$} & $\begin{array}{l}\text { Cyclooctene/ } \\
\text { Cyclohexene, } \\
\text { norbornene, indene, } \\
\text { Stilbene }\end{array}$ & $\begin{array}{l}\mathrm{H}_{2} \mathrm{O}_{2}+\mathrm{imi} \\
\text { dazole }\end{array}$ & $\begin{array}{l}60^{\circ} \mathrm{C}, \quad 24 \mathrm{~h} \text { in } \\
\mathrm{CH}_{3} \mathrm{CN} / 60^{\circ} \mathrm{C}, \\
4 \sim 24 \mathrm{~h} \text { in } \mathrm{CH}_{3} \mathrm{CN}\end{array}$ & $75 / 2-75$ & Epoxide & $\begin{array}{l}\text { Good activity for epoxidation of } \\
\text { cyclooctene, whereas aryl-substituted } \\
\text { olefins gave a low yield, slow release } \\
\text { of the active species }\end{array}$ & 110 \\
\hline 27 & $\begin{array}{l}\text { TMPyP@ }\left[\mathrm{Fe}_{3}(\mathrm{BTC})_{2}\right](\mathrm{TMPyP} \\
=\text { meso-Tetra } \mathrm{N}-\text { methyl-4- } \\
\text { pyridyl)porphine }\end{array}$ & $\begin{array}{l}\text { Styrene/ trans- } \\
\text { stilbene/ } \\
\text { triphenylethylene }\end{array}$ & $\begin{array}{l}\text { TBHP in } \\
\mathrm{H}_{2} \mathrm{O}\end{array}$ & $\begin{array}{l}60^{\circ} \mathrm{C} \text {, in } \mathrm{CH}_{3} \mathrm{CN} \\
\text { for } 10 \mathrm{~h}\end{array}$ & $85 / 40 /<5$ & Epoxide and benzaldehyde & $\begin{array}{l}\text { Heterogeneous porph@MOF catalyst } \\
\text { shows better conversion compare to } \\
\text { homogeneous catalyst, size selective }\end{array}$ & 111 \\
\hline
\end{tabular}




\begin{tabular}{|c|c|c|c|c|c|c|c|c|}
\hline 28 & $\begin{array}{ll}\text { tetratosylate }) & \text { (refer as } \\
\text { Porph@MOM-4) } & \\
\left.\left(\mathrm{CH}_{3}\right)_{2} \mathrm{NH}_{2}\right]\left[\mathrm{Zn}_{2}(\mathrm{HCOO})_{2}\left(\mathrm{M}^{\mathrm{II}}-\right.\right. \\
\mathrm{TCPP})\left(\mathrm{H}_{6} \mathrm{TCPP}=\right. & \text { tetrakis }(4- \\
\text { carboxyphenyl) } & \text { porphyrin }) \\
(\mathrm{M}=\mathrm{Fe} \text { or } \mathrm{Mn}) & \end{array}$ & $\begin{array}{l}\text { Styrene / variable } \\
\text { olefins }\end{array}$ & $\mathrm{PhIO}$ & RT. $6 \mathrm{~h}$ in $\mathrm{CH}_{2} \mathrm{Cl}_{2}$ & $>99 / 7 \sim>99$ & Styrene oxide and epoxides & $\begin{array}{l}\text { catalysis was observed based on the } \\
\text { three substrates with different sizes. } \\
\text { Efficient catalysts for selective } \\
\text { oxidation of various hydrocarbons at } \\
\text { RT. }\end{array}$ & 42 \\
\hline 29 & $\begin{array}{l}\text { PW } 11 \text { MIL-101(Cr) } \\
\text { SiW }_{11} @ M I L-101(\mathrm{Cr})\end{array}$ & R-(+)-limonene & $\mathrm{H}_{2} \mathrm{O}_{2}$ & $\begin{array}{l}75{ }^{\circ} \mathrm{C} \text {, in } \mathrm{CH}_{3} \mathrm{CN} \\
6 \text { h. } \\
\mathrm{H}_{2} \mathrm{O}_{2} / \text { substrate } \\
\text { molar ratio: } 4.5 / 1\end{array}$ & $\sim 95$ & $\begin{array}{l}\text { Limonene-1,2-epoxide } \\
\text { Limonene-1,2-diol }\end{array}$ & $\begin{array}{l}\text { The kinetic profile of PW11 and } \\
\text { PW11@MIL-101 is similar. No } \\
\text { selectivity concerning product } \\
\text { distribution is given. }\end{array}$ & 112 \\
\hline 30 & $\mathrm{Fe}_{2} \mathrm{O}_{3} / \mathrm{MIL}-101(\mathrm{Cr})$ & $\begin{array}{l}\text { Alkenes } \\
\text { cyclohexenes }\end{array}$ & $\begin{array}{l}\mathrm{H}_{2} \mathrm{O}_{2}(50 \\
\text { wt.\%) }\end{array}$ & $\begin{array}{l}3 \sim 15 \min , \text { in water, } \\
100 \sim 120 \quad{ }^{\circ} \mathrm{C}, \\
(8.3 \sim 13.4 \mathrm{bar}) \\
\text { Microwave } \\
\text { assisted(300W) }\end{array}$ & $\begin{array}{l}88 \sim 95 \\
92\end{array}$ & $\begin{array}{l}\text { Corresponding benzaldehydes } \\
(90 \sim 95 \%) \\
\text { cyclohexane-1,2-dione( } 86 \%)\end{array}$ & $\begin{array}{l}\text { Recyclable up to } 3 \text { runs. } \\
\text { MIL-101 is a good catalyst/support for } \\
\text { under pressure and oxidising } \\
\text { conditions. }\end{array}$ & 71 \\
\hline 31 & $\begin{array}{l}\mathrm{Zn}_{4} \mathrm{O} \text { based } \mathrm{MOFs} \text { (MOF-5, } \\
\text { IRMOF-2, } \\
\text { IRMOF-9) }\end{array}$ & $\begin{array}{l}\text { Propene } \\
\text { Propylene }\end{array}$ & $\mathrm{O}_{2}$ & $\begin{array}{l}\text { RT, } 60 \mathrm{~min} \\
\text { illumination, gas } \\
\text { mixutre of } 28.5 \\
\text { mol \% propene } \\
\text { and } 14.3 \mathrm{~mol} \% \mathrm{O}_{2} \\
\text { from dry air. Flow } \\
\text { rate } 10 \mathrm{ml} / \mathrm{min} \\
\text { (operando FT-IR) }\end{array}$ & - & $\begin{array}{l}\text { propanoic acid, ketones, } \\
\text { aliphatic aldehydes } \\
\text { acrylic acid, acrolein, acetone }\end{array}$ & $\begin{array}{l}\text { The photo catalytic activity of the } \\
\text { Zn } 40 \text { based clusters turned out to be } \\
\text { higher than that of their MOF } \\
\text { counterparts and that of zinc oxide in } \\
\text { the oxidation of propene. }\end{array}$ & 113 \\
\hline
\end{tabular}




\subsubsection{Cu based MOFs}

Only a few studies have been carried out on $\mathrm{Cu}-\mathrm{MOF}$ for the oxidation of alkenes (entries 1-4 Table 4). In the first two reports pure $\mathrm{O}_{2}$ was applied as an oxidant (entry 1 and 4, Table 4), whereas in the third report $\mathrm{H}_{2} \mathrm{O}_{2}$ (entry 2, Table 4) and in the last study TBHP was employed as an oxidant (entry 3, Table 4). In spite of the low cyclohexene conversion $^{85}(8 \%)$, very good selectivities toward cyclohexene hydroperoxide (Scheme 10, product 6) were obtained (90\%) using $\mathrm{O}_{2}$. The use of $\mathrm{H}_{2} \mathrm{O}_{2}$ as an oxidant mainly gave the allylic oxidation product 2-cyclohexene-1-one (entry 2 Table 4 ).

Aguirre et al. ${ }^{87}$ show that $\mathrm{Cu}$-based MOFs can also possess a good selectivity towards the epoxide (entry 3 Table 4). Although a significant difference is observed in the conversion of both reactants (cyclohexene and styrene), a selectivity of approximately $70 \%$ toward the epoxide was detected in both cases. In an additional report, the authors proposed a mechanism for the formation of the epoxide and they ascribed the difference in conversion for cyclohexene and styrene to the mechanism involved in the oxidation reaction ${ }^{88}$.

\subsubsection{Co-based MOFs}

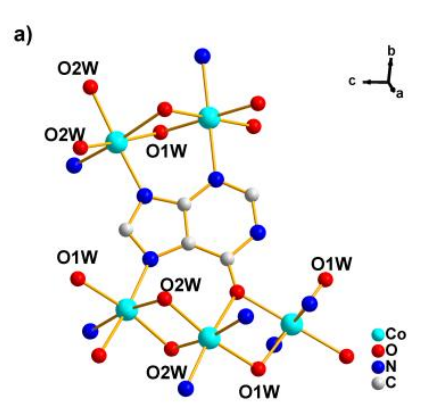

b)

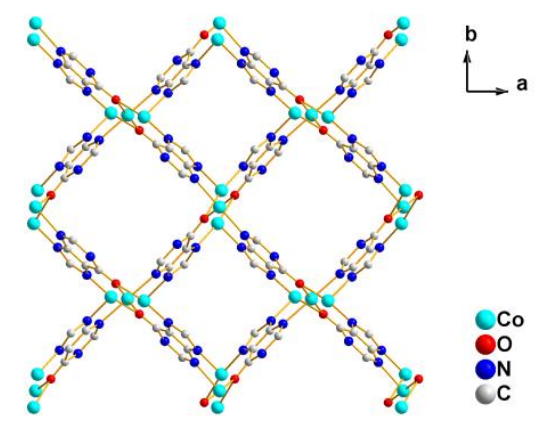

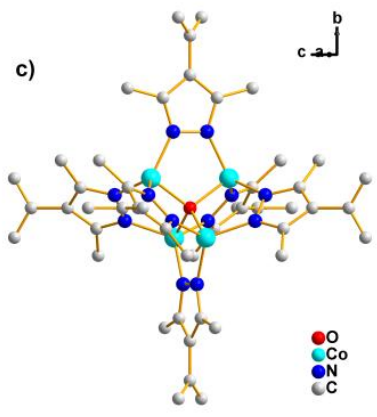

Figure 3 a,b) the coordination surroundings of $\mathrm{Co}$ in $\left[\mathrm{Co}_{3}\left(\mu_{2}-\mathrm{OH}\right)_{4}(\mathrm{I})_{2}\right]$ as well as the $3 \mathrm{D}$ porous framework $\left.{ }^{115} \mathrm{c}\right)$ the $\mathrm{SBU}$ of MFU-1 framework

Several Co containing MOFs have been evaluated for the oxidation of alkenes (entries 4-9 Table 4). Many attempts have been made to get novel structures containing unsaturated cobalt sites. As shown in Figure 3, two Co-MOF structures, $\left[\mathrm{Co}_{3}\left(\mu_{2}-\mathrm{OH}\right)_{4}(\mathrm{I})_{2}\right]$ and MFU-1 are given as examples. MFU-1 is designed by the group of Volkmer, they applied TBHP as an oxidant for the evaluation of their CoMOFs (entries 5-6 Table 4) ${ }^{11,90}$. In both studies very high selectivities were obtained toward the allylic substitution product, tert-butyl-2-cyclohexenyl-1-peroxide (83\%) (Scheme 10, product 4), suggesting a mechanism in which peroxy radicals are created by a reductive cleavage of tert-butyl hydroperoxo ligands coordinating to $\mathrm{Co}(\mathrm{III})$ metal centers.

In a later report ${ }^{91}$, more mechanistic insights were given and additional catalytic tests were executed. Whereas the MFU-1 material demonstrated to be a stable catalyst, the catalytic activity of MFU-2 was due to the slow leaching of the Co centers using TBHP as an oxidant (entry 7 Table 4) ${ }^{91}$. 
Zhang et al. applied $\mathrm{O}_{2}$ combined with the sacrificial isobutyraldehyde to test a Co-ZIF for the oxidation of various alkenes (entry 8 Table 4$)^{92}$. Under these conditions, the epoxide product was formed with very high selectivities (98.5\%). The authors ascribed these results to a combined effect of the basic ligand and the unsaturated metal center, since epoxides are fairly stable in a basic medium ${ }^{92}$. They suggested a radical mechanism (see Scheme 11). In first instance, an in situ acylperoxy radical was created as a result of the reaction of isobutyraldehyde with $\mathrm{O}_{2}$ initiated by Co-ZIF. In a second step, the acylperoxy radical is able to follow 2 possible pathways, it can either react with the olefin to produce the epoxide, or with the Co-ZIF to form Co-peroxy species, which on their turn can transfer an oxygen atom directly to the olefins.

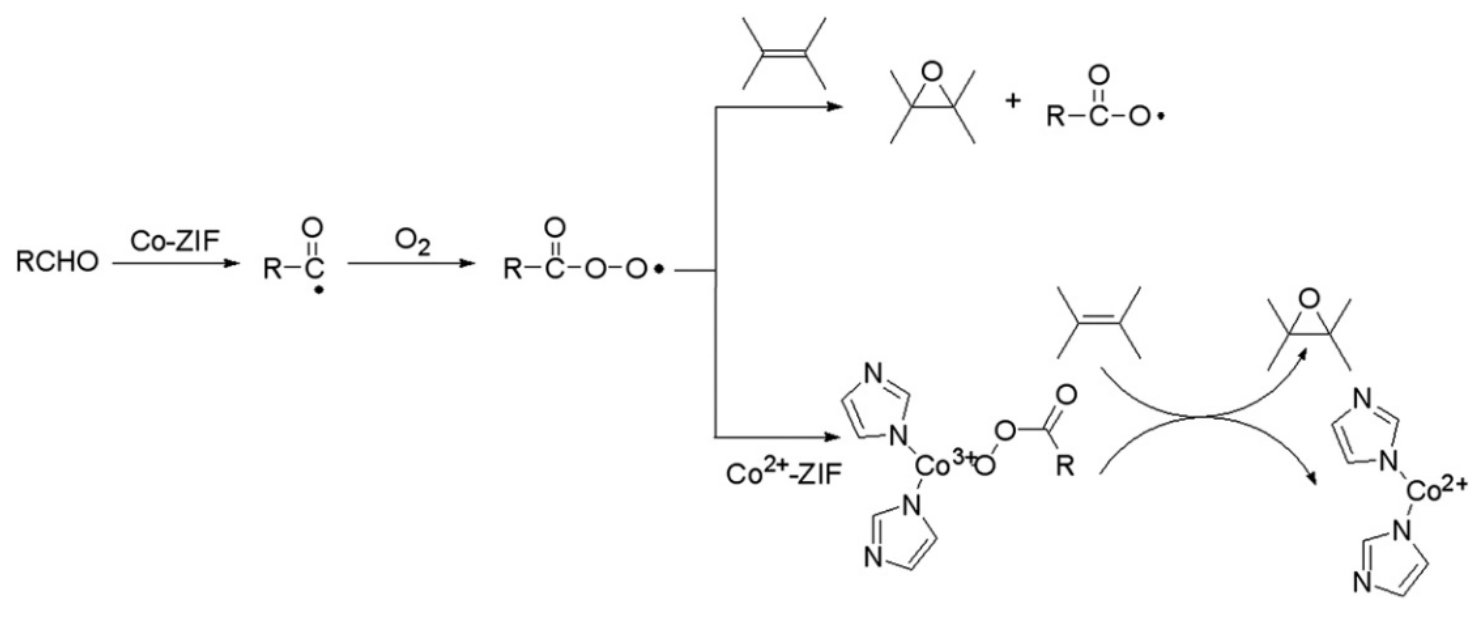

Scheme 11. Proposed pathway by Zhang et al. for the selective epoxidation of olefins catalyzed by Co-ZIF. Reproduced with permission from ref ${ }^{92}$. Copyright 2011 Elsevier.

In a report of Beier et al. ${ }^{93}$, pure $\mathrm{O}_{2}$ was applied as an oxidant with DMF as a solvent (entry 9 Table 4). Former studies on Co-catalysts revealed that in the presence of DMF, a Co-DMF complex is formed that reacts with $\mathrm{O}_{2}$ giving rise to Co-superoxo species ${ }^{116}$. As mentioned earlier, these species will afterwards transfer the oxygen to the olefin, resulting in the epoxide product. The catalytic evaluation of Co-STA-12 resulted in the formation of the epoxide with an excellent selectivity of $90 \%$, which was in agreement with the proposed mechanism ${ }^{93}$.

\subsubsection{Rare-earth based MOFs}

Although homogenous rare-earth salts have already shown to possess good catalytic performance for the oxidation of olefins, the reports using rare-earth MOFs in the epoxidation of alkenes are very scarce ${ }^{117}$. Rare earth metals act as Lewis acids, forming adducts with the peroxo groups of $\mathrm{H}_{2} \mathrm{O}_{2}$ or TBHP similar to early transition metals in a high oxidation state. In recent years, Sen et al. reported two papers concerning the use of rare-earth based carboxylate MOFs in the oxidation of alkenes (entries 10-11 Table 4) ${ }^{94-95}$. Similarities between both studies were observed. Firstly, TBHP was seen as the most appropriate oxidant. Very little or no catalytic activity was observed when $\mathrm{H}_{2} \mathrm{O}_{2}$ or sodium hypochlorite was applied. Moreover, in both cases a higher conversion was noted for the MOF based catalysts than for the corresponding metal oxides.

\subsubsection{V based MOFs}


Our own research efforts were mainly focused on the catalytic evaluation of V-MOFs. MIL-47, a V(IV) terephthalate MOF with completely coordinatively saturated V-nodes was tested in the oxidation of cyclohexene employing TBHP in water or TBHP in decane as oxidant (entry 12 Table 4$)^{96 a}$. With the water based oxidant, a similar cyclohexene conversion and product distribution was observed in comparison with the geometrically and structurally wise homogeneous catalyst $\mathrm{VO}(\mathrm{acac})_{2}$. Nevertheless, a significant leaching of $\mathrm{V}$-species into the solution (12.8\% after one hour of reaction) was detected. If the TBHP was dissolved in decane as solvent the leaching of $\mathrm{V}$ becomes negligible and the catalyst was reused for at least 4 runs without loss of the structural integrity of the framework. Theoretical calculations were carried out to elucidate the active species and to propose a plausible reaction pathway (Scheme 12). At least two catalytic cycles are co-existing: one with $\mathrm{V}^{+\mathrm{IV}}$ sites and one with pre-oxidized $\mathrm{V}^{\mathrm{V}}$ sites. In the first cycle a direct epoxidation pathway is proposed that leads to the formation of cyclohexene oxide $\mathbf{2}$, whereas the second cycle follows a radical based mechanism. In this route, $+\mathrm{V}$ vanadium-complexes 9 are generated by a homolytic cleavage of the peroxy linkage which can be activated with TBHP. The generated $\mathrm{V}^{\mathrm{V}}$-activated complexes $\mathbf{1 0}$ and $\mathbf{1 2}$ can on their turn produce cyclohexene oxide $^{96 c}$.

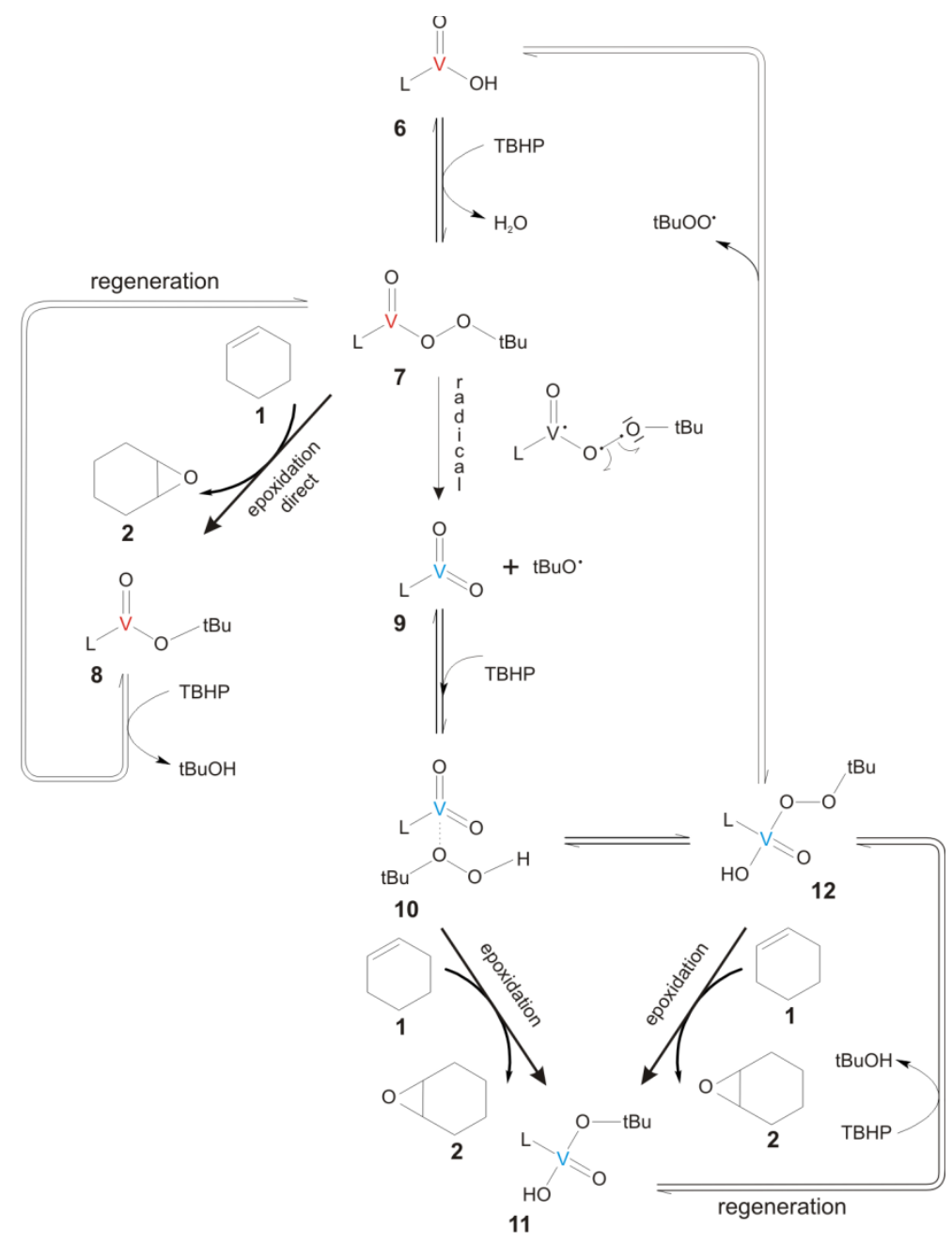


Scheme 12. Two competitive cyclohexene epoxidation pathways for MIL-47 (direct and radical) $\left(\mathrm{V}^{+\mathrm{IV}}\right.$ is shown in red, $\mathrm{V}^{+\mathrm{V}}$ is shown in blue and $\mathrm{V}^{+\mathrm{III}}$ is represented in black). Reproduced with permission from ref ${ }^{96 c}$. Copyright 2012 Elsevier

Another $\mathrm{V}^{\mathrm{IV}}$ terephthalate, denoted as COMOC-3, exhibiting the non-porous MIL-69 topology, was also examined in the oxidation of cyclohexene applying TBHP in decane as the oxidant (entry 13 Table 4) $)^{97,118}$. A similar cyclohexene conversion was observed for COMOC-3 as for the porous MIL47-catalyzed reaction under the same conditions. This suggests that the activity is driven by surface defect sites. A new $\mathrm{V}_{4} \mathrm{O}_{9}$ phase was detected, probably due to the surface activation and bond breaking during catalysis in combination with the oxidizing atmosphere during the regeneration of the catalyst ${ }^{97}$.

\subsubsection{MOFs as hosts for POMs or complexes}

\section{POM@MOF}

$\mathrm{Co}$ and $\mathrm{Ti}$-monosubstituted Keggin heteropolyanions were inserted into the nanocages of Cr-MIL$101^{99}$. During the catalytic evaluation of the resulting POM@MOF materials, two types of oxidant were applied: $\mathrm{O}_{2}$ for the Co-POM and $\mathrm{H}_{2} \mathrm{O}_{2}$ for the Ti-POM (entry 15 Table 4). Both systems gave foremost the allylic product in the oxidation of $\alpha$-pinene. In addition, in the oxidation of cyclohexene over Ti-POM@MIL-101, the allylic oxidation products cyclohexene-2-ol and cyclohexene-2-one were the main products as well. In turn, the oxidation of caryophyllene mostly gave the epoxide product. The authors state that this could be due to the deprotonation of the Ti-POM during the encapsulation within the host matrix preventing the acid-sensitive epoxide for the ring opening reaction ${ }^{99}$.

Later on, the same group reported on the incapsulation of the polyoxotungstates $\left[\mathrm{PW}_{4} \mathrm{O}_{24}\right]^{3-}\left(\mathrm{PW}_{4}\right)$ and $\left[\mathrm{PW}_{12} \mathrm{O}_{40}\right]^{3-}\left(\mathrm{PW}_{12}\right)$ into MIL-101 which were examined for the oxidation of cyclohexene and other cyclic alkenes by means of $\mathrm{H}_{2} \mathrm{O}_{2}$ as an oxidant (entry 16 Table 4$)^{100}$. For these POM@MOF materials, not the allylic but the epoxide product was observed as the main product. Furthermore, the authors witnessed an enhanced stability of the immobilized POM in the presence of $\mathrm{H}_{2} \mathrm{O}_{2}$.

The Hatton group made a PTA@Cr-MIL-101 (PTA=phosphotungstic acid) material (entry 17 Table 4) for which much higher TOF values are reported (approximately 22-fold higher) than the TOF obtained for Ti-POM@MIL-101 under identical reaction conditions (entry 15 Table 4 ) ${ }^{101}$. They attributed this to the use of microwave heating and its effect on the grain size.

complex@MOF

Dhakshinamoorthy et al. reported the NHPI@FeBTC for the aerobic oxidation of styrene and derivates (entry 19 Table 4$)^{103}$. In earlier times this MOF was already investigated for the aerobic oxidation of cyclooctane and other benzylic compounds (see entry 6 Table 1$)^{36}$. A similar mechanism was proposed (Scheme 7) with the generation of phthalimide $N$-oxyl radicals acting as precursors of C-centered radicals that would undergo auto-oxidation. Ingleson et al. ${ }^{104}$ reported the two steps modification of IRMOF-3 to an imine grafted $\mathrm{VO}(\mathrm{acac})_{2}$ complex (entry 20 Table 4). The authors carried out a preliminary catalytic investigation on this modified MOF structure for the oxidation of cyclohexene with TBHP as the oxidant. However, the VO(acac) $)_{2} @$ IRMOF-3 showed a rather low catalytic activity and stability ${ }^{104}$. The group of Ahn reported a more straightforward one step functionalization of the IRMOF-3 with a manganese complex (entry 21 Table 4) ${ }^{105}$. Instead of using TBHP as an oxidant they utilized $\mathrm{O}_{2}$ in combination with trimethylacetaldehyde as a co-oxidant. Good conversions (even for the 
more bulky cyclooctene) were obtained with very high selectivities toward the epoxide $(>80 \%){ }^{105}$. Very recently, we performed a similar post-modification of $\mathrm{NH}_{2}-\mathrm{MIL}-47$, with $\mathrm{TiO}(\mathrm{acac})_{2}$. The catalytic performance of V/Ti-MOF was examined for the oxidation of cyclohexene using $\mathrm{O}_{2}$ as oxidant in combination with cyclohexanecarboxaldehyde as co-oxidant. A significantly higher cyclohexene conversion (25\%) was observed for the bimetallic catalyst compared to the nonfunctionalized material (14.1\%). The catalyst could be regenerated for at least 2 additional cycles without loss of activity and stability (entry 14 Table 4$)^{98}$.

The success of the immobilization of a homogeneous catalyst was once more demonstrated in the report of Lee et al. ${ }^{106}$ in which a Mn(III)-porphyrin based MOF was synthesized resulting in an increased catalytic activity and lifetime in comparison to its homogeneous counterpart (entry 22 Table 4). Also the Hupp group synthesized a MOF incorporating a series of metalloporphyrins $\left(\mathrm{Al}^{3+}, \mathrm{Zn}^{2+}\right.$, $\mathrm{Pd}^{2+}, \mathrm{Mn}^{3+}$ and $\mathrm{Fe}^{3+}$ complexes) in which the Mn containing MOF exhibited promising results for the oxidation of styrene (entry 23 , Table 4 ) and the hydroxylation of cyclohexane ${ }^{107}$.

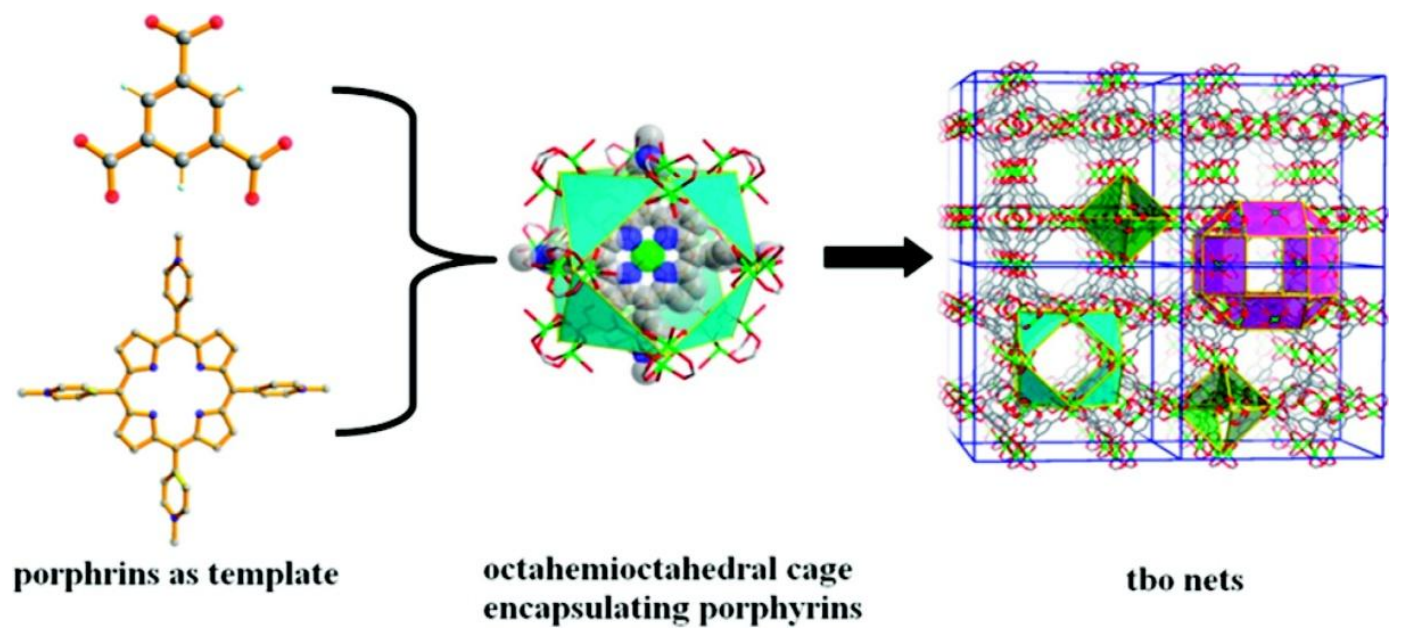

Figure 4 (right) Polyhedral cage framework of porph@MOM-4, -5, and -6 containing three distinct cages: large rhombihexahedral cages (pink), medium-sized octahemioctahedral cages (turquoise), and small tetrahedral cages (green). (middle) TMPyP cation encapsulated in the octahemioctahedral cage. (left) Structures of BTC and TMPyP. Reprinted with permission from Ref. ${ }^{111}$ Copyright (2012) American Chemical Society

More recently, Z. Zhang et al. ${ }^{111}$ reported a "ship-in-a-bottle" encapsulation of metaloporphyrins in a series of MOFs. As shown in Figure 4, the metaloporphyrins are located in the octahemioctahedra cages and serves as size-selective catalysts for oxidation of olefines (entry 27 Table 4).

\subsection{MOFs in chiral oxidation catalysis}

In Table 5 an overview is presented of the MOFs examined in the chiral oxidation of different substrates. Besides their use in oxidation catalysis, chiral MOFs have already been tested for a variety of reactions (diethylzinc additions, transesterifications, aldol reactions, hydrogenation, cyanosilylation reactions...). As the discussion of each type of catalytic reaction falls beyond the scope of this review the reader is referred to the recent and comprehensive overview of Kim et al. ${ }^{119}$. We will here focus on chiral oxidation catalysis. 

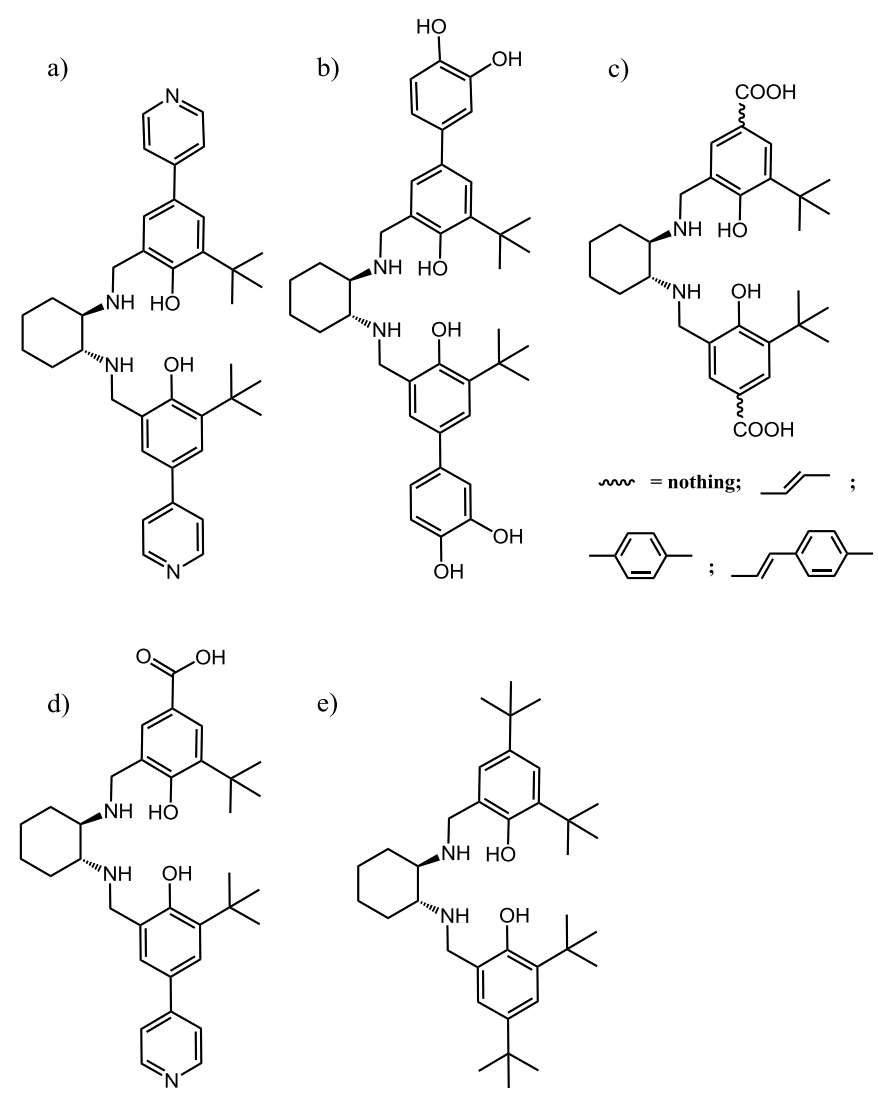

Scheme 13. Various metalated salen /salan ligands used in this chapter to construct MOFs for chiral oxidation catalysis. a)

6,6'-(((1R,2R)-cyclohexane-1,2-diylbis(azanediyl))bis(methylene))bis(2-(tert-butyl)-4-(pyridin-4-yl)phenol); b) 5',5"'-

(((1R,2R)-cyclohexane-1,2-diylbis(azanediyl))bis(methylene))bis(3'-(tert-butyl)-[1,1'-biphenyl]-3,4,4'-triol); c) 5,5'(((1R,2R)-cyclohexane-1,2-diylbis(azanediyl))bis(methylene))bis(3-(tert-butyl)-4-hydroxybenzoic acid) and its derivatives;

d) 3-(tert-butyl)-5-((((1R,2R)-2-((3-(tert-butyl)-2-hydroxy-5-(pyridin-4-yl)benzyl)amino)cyclohexyl)amino)methyl)-4hydroxybenzoic acid; e) 6,6'-(((1R,2R)-cyclohexane-1,2-diylbis(azanediyl))bis(methylene))bis(2,4-di-tert-butylphenol)

The very first report on chiral oxidation catalysis was presented by Cho et al. ${ }^{120}$ in which an Zn based MOF containing a Jacobsen-type salen(Mn) catalyst (salen ligand is shown in scheme 13a) showed promising results in the asymmetric epoxidation of 2,2-dimethyl-2H-chromene applying 2-(tertbutylsulfonyl)iodosylbenzene as oxidant (entry 4, Table 5). The polymerized salen complex exhibited an enhanced lifetime and only a minor selectivity degradation $(82 \%$ ee) in comparison to the homogeneous complex $(88 \%$ ee). The authors attributed the difference in enantioselectivity to electronic effects, more specifically to the presence of electron-withdrawing groups, whereas the research group of Snurr ascribed the decreased enantioselectivity to sterical hindrance between the substrate and the framework along with a decreased flexibility of the salen complex ${ }^{121}$.

In a later report of Cho et al. another salen based coordination polymer was described (Scheme $13 \mathrm{~b}$, entry 3, Table 5). In contrast to their previous work, this catalyst could be recycled up to ten times with only a slight leaching percentage in the first 6 cycles ${ }^{122}$. Furthermore, they presented a porous, noncatenated analogue (denoted as $\mathrm{Mn}^{\mathrm{III}} \mathrm{SO}-\mathrm{MOF}$ ) of their first Jacobsen catalyst based $\mathrm{Zn}-\mathrm{MOF}$ (entry 8, Table 5) . Evaluation of the latter in the asymmetric epoxidation of 2,2-dimethyl- $2 \mathrm{H}$ chromene gave very high TON values (nearly 4000) ${ }^{123}$. Additionally, removal of the Mn ions of the $\mathrm{Mn}{ }^{\mathrm{III}} \mathrm{SO}-\mathrm{MOF}$ material and subsequently remetallation was carried out. A comparison of the $\mathrm{Mn}^{\mathrm{III}} \mathrm{SO}-$ MOF with the remetallated Mn ${ }^{\mathrm{II}} \mathrm{SO}-\mathrm{MOF}$ (entry 9, Table 5) demonstrated that for the latter a longer 
induction period was observed due to the fact that the $\mathrm{Mn}^{\mathrm{II}}$ center needs to be oxidized to $\mathrm{Mn}^{\mathrm{III}}$ before catalysis can occur $^{19 b}$.

Other Salen based MOFs were developed by the group of Lin who synthesized an isoreticular series of Mn-Salen based Zn-MOFs, denoted as CMOF-1 to CMOF-5 (Scheme 13c) (entry 2, Table 5). This family of isoreticular chiral MOFs was examined in the epoxidation of different olefins affording good to excellent yields and ee's ${ }^{124}$. Furthermore they noticed that the rates of the epoxidation reaction strongly depend on the channel sizes. Nevertheless, the inherent instability of the CMOFs (7.5\% Mn leaching) limits their use in enantioselective epoxidation reactions. In another recent work of Lin a different $\mathrm{Mn}$ (salen) ligand was applied to synthesize a chiral MOF having the same SBU as in one of their previous works (entry 1, Table 5) ${ }^{125}$ which was the first MOF catalyzing sequential alkene epoxidation/epoxide ring-opening reactions.

Huang et al. reported a more stable chiral functionalized nickel Salen based MOF (Scheme 13a) which was insoluble in water and other common organic solvents (entry 7 , Table 5$)^{126}$. The latter compound showed a similar catalytic activity as the homogeneous catalyst and could be recycled for at least 3 runs without loss in epoxide selectivity and only a minor loss in conversion ${ }^{126}$.

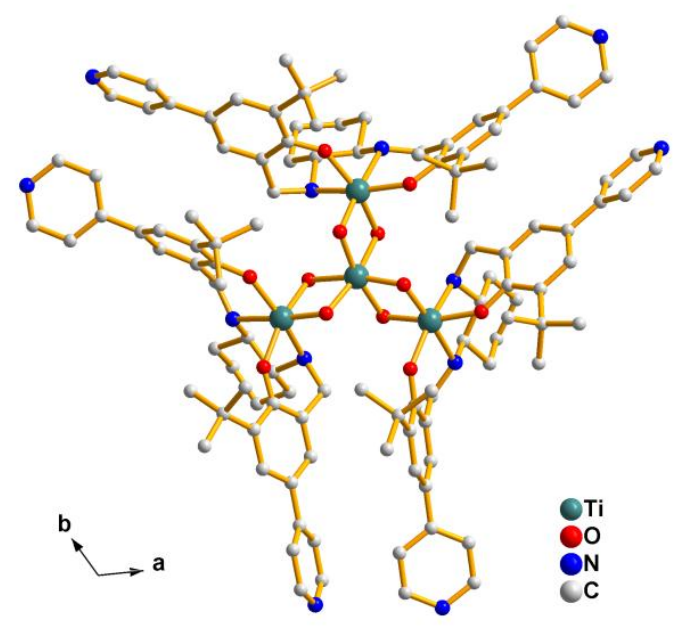

Figure 5. $\mathrm{Ti}_{4} \mathrm{O}_{6} \mathrm{~L}_{3}$ cluster as the basic building unit of a salan based MOF structure, salan ligand $\mathrm{H}_{2} \mathrm{~L}$ are shown in $\mathrm{Scheme}$ $13 \mathrm{a}$

An interesting salan based MOF structure has been reported by the research group of $\mathrm{Cui}^{127}$, as shown in Figure 5, The framework containing salan-bound $\mathrm{Ti}_{4} \mathrm{O}_{6}$ clusters which act as the building unit as well as the active catalytic center. The MOF is shown to be an efficient and recyclable heterogeneous catalyst for the oxidation of thioethers to sulfoxides by aqueous $\mathrm{H}_{2} \mathrm{O}_{2}$ (up to $82 \%$ ee) (Table 5, entry 11), displaying markedly enhanced enantioselectivity over the homogeneous catalyst by providing a cavity confinement effect. A similar approach has been employed by the same group using another Tibased salan complex (Scheme 13d) to form a salan complex based MOF structure, the obtained MOF catalyst also shows good selectivity (up to $62 \%$ ee) in the oxidation of sulfides to sulfoxides(Table 5 , entry 12$).{ }^{128}$

Whereas the previous studies report on the application of chiral MOFs in the epoxidation of alkenes, Dybtsev et al. examined a homochiral Zn MOF in the size- and chemoselective oxidation of thioethers (entry 5, Table 5) ${ }^{129}$. The chiral MOF exhibited a reasonable conversion (58-64\%) for the smaller 
thioethers whereas for the bulkier thioethers a very poor conversion was noted. Although the authors could recycle the catalyst for 30 catalytic cycles, they failed to observe any asymmetric induction in the catalytic sulfoxidation. In a later report this MOF was applied at the same time as a catalyst and as a chiral stationary phase for a column to obtain enantiomerically pure sulfoxides ${ }^{130}$. However, the enantioseparation of the bulkier sulfoxides could not be obtained due to the relative small pore dimensions of the MOF. To overcome this problem, the same research group synthesized 2 isoreticular homochiral MOFs applying bigger linkers which could be used in the sulfoxidation of bulkier thioethers (entry 6, Table 5) ${ }^{131}$.
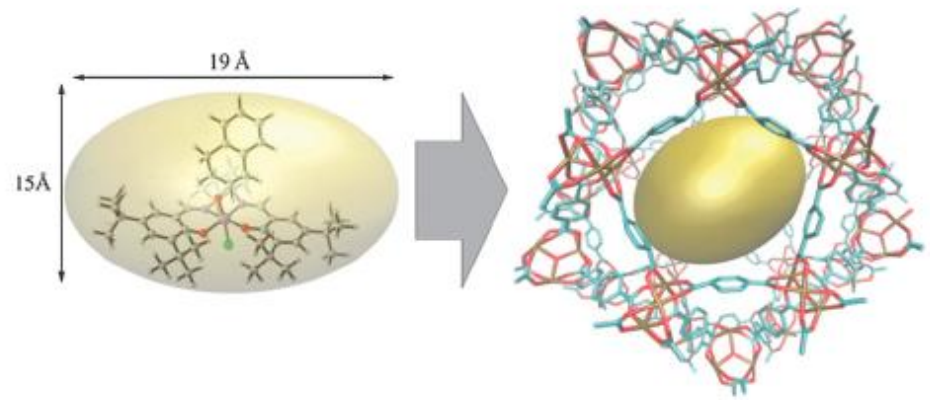

Figure 6. Schematic representation of the transition state contained in the small (2.9 nm diameter) cage of MIL-101.

The space needed for transition state to be contained in the cage is represented by an ellipsoid with radii of 19 and $15 \AA$.

This fits readily in the MIL-101 cage. Reproduced by permission of The Royal Society of Chemistry [ref ${ }^{132}$ ]

In order to overcome the stability problems that many MOFs with chiral struts are dealing with, our group has recently published a Jacobsen salen complex (Scheme 13e), that was immobilized inside the pores of an $\mathrm{NH}_{2}$-MIL-101(Al), using a "bottle around the ship" approach ${ }^{132}$. This, by the way, also prevents the dimerization of the Mn-salen complex, rendering it useless and inactive. As shown in Figure 6, the dimensions of the Jacobsen salen complex (approximately $1.7 \times 1.2 \times 0.5 \mathrm{~nm}$ ) allow it to reside in the cages (2.9-3.4 nm, connected by windows of 1.2 and $1.6 \mathrm{~nm}$ ) without being able to pass through the windows, thus effectively immobilizing the complex. The trapping of the active complex without any covalent or coordinative bonds keeps the structure in the optimal shape needed for achieving the high selectivity. This catalyst was tested for up to four runs with a minimal decrease in activity and complete retention of the selectivity. We also calculated that the transition state (that determines the selectivity) fits the pores of the host unhindered, allowing the reaction to exhibit the same behavior as with the homogeneous catalyst.

Table 5. Overview of MOFs examined for in chiral oxidation catalysis

\begin{tabular}{|c|c|c|c|c|c|c|c|c|}
\hline $\begin{array}{l}\text { Ent } \\
\text { ry }\end{array}$ & Catalytic MOF & Reactant & Oxidant & $\begin{array}{l}\text { Reaction } \\
\text { parameters }\end{array}$ & $\begin{array}{l}\text { Convers } \\
\text { ion (\%) }\end{array}$ & $\begin{array}{l}\text { Main } \\
\text { product } \\
(\mathrm{ee} \%)\end{array}$ & $\begin{array}{l}\text { Take home } \\
\text { message }\end{array}$ & $\begin{array}{l}\operatorname{Re} \\
\text { f. }\end{array}$ \\
\hline 2 & $\begin{array}{l}\text { CMOF-n } \quad(n=1 \sim 5) \\
\left.\text { O)(L })_{3}\right] \\
\text { Mn־salen complex }\end{array}$ & $\begin{array}{l}1 H \text {-indene } \\
(\mathrm{CMOF}-1,3,5)\end{array}$ & $\begin{array}{l}2 \text {-(tert } \\
\text { butylsulfonyl) } \\
\text { iodosylbenzene }\end{array}$ & $\begin{array}{l}\mathrm{RT}, \quad 0.5 \mathrm{~h} \text { in } \\
\mathrm{CH}_{2} \mathrm{Cl}_{2}, \quad, \quad 0.5 \\
\text { equiv. of oxidant }\end{array}$ & $54 \sim 80$ & $\begin{array}{l}(1 \mathrm{R}, 2 \mathrm{~S}) \text { - } \\
\text { indene } \\
\text { oxide } \\
(47 \sim 64)\end{array}$ & $\begin{array}{l}\text { Rate of } \\
\text { epoxidation } \\
\text { reaction } \\
\text { depend on } \\
\text { the CMOF }\end{array}$ & 124 \\
\hline
\end{tabular}




\begin{tabular}{|c|c|c|c|c|c|c|c|c|}
\hline & & $\begin{array}{l}\text { Unfunctionaliz } \\
\text { ed alkenes } \\
(\mathrm{CMOF}-4,5)\end{array}$ & & & $60-99$ & $\begin{array}{l}\text { Epoxide } \\
(39-92)\end{array}$ & $\begin{array}{l}\text { open channel } \\
\text { size }(7.5 \% \text { of } \\
\text { the Mn-salen } \\
\text { complex was } \\
\text { leached out). }\end{array}$ & \\
\hline 3 & $\begin{array}{l}\text { poly }(\mathrm{Cu}-1)=\mathrm{Cu}^{-} \\
\text {linked(salen) } \mathrm{Mn} \text {-polymer } \\
\text { poly }(\mathrm{M}-1) \text { with } \mathrm{M}=\mathrm{Cr}, \mathrm{Mn}, \mathrm{Fe}, \\
\mathrm{Co}, \mathrm{Ni}, \mathrm{Zn}, \mathrm{Cd}, \mathrm{Mg}\end{array}$ & $\begin{array}{l}2,2 \text {-dimethyl- } \\
2 H \text {-chromene }\end{array}$ & $\begin{array}{l}2-\left(\text { tert }^{-}\right. \\
\text {butylsulfonyl) } \\
\text { iodosylbenzene }\end{array}$ & $\begin{array}{l}\text { Molar ratio } \\
\text { olefin/oxidant/cat } \\
\text { alyst= } 100 / 150 / 1, \\
2 \mathrm{~h} \text { in } \mathrm{CH}_{2} \mathrm{Cl}_{2}\end{array}$ & $22-89$ & $\begin{array}{l}\text { Epoxide } \\
(76) \\
\\
\text { Epoxide } \\
(20-76)\end{array}$ & $\begin{array}{l}\text { Recycled up } \\
\text { to } 10 \text { times } \\
\text { with little } \\
\text { loss in } \\
\text { activity and } \\
\text { no loss in } \\
\text { enantioselect } \\
\text { ivity }\end{array}$ & 122 \\
\hline 4 & $\begin{array}{l}\mathrm{Zn}_{2}(\mathrm{bpdc})_{2}(\mathrm{~L}) \cdot 10 \quad \text { DMF. } 8 \mathrm{H}_{2} \mathrm{O} \\
\text { with } \mathrm{L}=\text { salen }(\mathrm{Mn}) \text { struts }\end{array}$ & $\begin{array}{l}2,2 \text {-dimethyl- } \\
2 H^{-} \text {-chromene }\end{array}$ & $\begin{array}{l}2 \text {-(tert- } \\
\text { butylsulfonyl) } \\
\text { iodosylbenzene }\end{array}$ & $\begin{array}{l}\text { Molar ratio } \\
\text { olefin/oxidant/cat } \\
\text { alyst= } \\
4000 / 2000 / 1, \quad 2 \mathrm{~h} \\
\text { in } \mathrm{CH}_{2} \mathrm{Cl}_{2}\end{array}$ & $66^{-71}$ & $\begin{array}{l}\text { Epoxide } \\
(82)\end{array}$ & $\begin{array}{l}\text { Higher } \\
\text { stability, } \\
\text { easier } \\
\text { separation, } \\
\text { recyclability } \\
\text { and } \\
\text { substrate } \\
\text { size } \\
\text { selectivity }\end{array}$ & 120 \\
\hline 5 & {$\left[\mathrm{Zn}_{2}(\mathrm{bdc})(\mathrm{L}-\mathrm{lac})(\mathrm{dmf})\right] .(\mathrm{DMF})$} & $\begin{array}{l}\text { Thioethers with } \\
\text { small and } \\
\text { bulkier } \\
\text { substituents }\end{array}$ & $\begin{array}{l}\text { Urea } \\
\text { hydroperoxide } / \mathrm{H}_{2} \\
\mathrm{O}_{2}\end{array}$ & $\begin{array}{l}\mathrm{RT}, \quad 16 \mathrm{~h} \text { in } \\
\mathrm{CH}_{2} \mathrm{Cl}_{2}, \mathrm{CH}_{3} \mathrm{CN} \\
\text { or } \mathrm{CH}_{2} \mathrm{Cl}_{2} / \mathrm{CH}_{3} \mathrm{CN}\end{array}$ & $3-99$ & Sulfoxide & $\begin{array}{l}\text { Could be } \\
\text { reused at } \\
\text { least } 30 \\
\text { times, } \\
\text { however no } \\
\text { asymmetric } \\
\text { induction } \\
\text { was observed }\end{array}$ & 129 \\
\hline 6 & $\begin{array}{l}{\left[\mathrm{Zn}_{2}(\mathrm{ndc})\{(\mathrm{R})-\operatorname{man}\}(\mathrm{dmf})\right] .3 \mathrm{DMF}} \\
{\left[\mathrm{Zn}_{2}(\mathrm{bpdc})\{(\mathrm{R})-\operatorname{man}\}(\mathrm{dmf})\right]} \\
2 \mathrm{DMF}\end{array}$ & $\begin{array}{l}2-\mathrm{NaphSMe} / \\
\mathrm{PhSCH}_{2} \mathrm{Ph}\end{array}$ & $\mathrm{H}_{2} \mathrm{O}_{2}$ & $\begin{array}{l}\mathrm{RT}, \quad 16 \mathrm{~h} \text { in } \\
\mathrm{CH}_{3} \mathrm{CN}\end{array}$ & $\begin{array}{l}78 / 70 \\
57 / 78\end{array}$ & Sulfoxide & & 131 \\
\hline 7 & $\begin{array}{l}{\left[\mathrm{Ni}_{3}(\mathrm{bpdc})(\mathrm{RR}-\mathrm{L})_{2} \cdot(\mathrm{DMF})\right]_{\mathrm{n}} \text { with }} \\
\mathrm{L}=\operatorname{Salen}(\mathrm{Ni}) \text { complex }\end{array}$ & $\begin{array}{l}\text { Styrene/cyclohe } \\
\text { xene }\end{array}$ & $\mathrm{NaClO}$ & $\begin{array}{l}\mathrm{RT}, \quad 24 \mathrm{~h} \text { in } \\
\mathrm{CH}_{2} \mathrm{Cl}_{2}\end{array}$ & $22 / 34$ & Epoxide & $\begin{array}{l}\text { Catalytic } \\
\text { activity } \\
\text { similar to the } \\
\text { homogeneous } \\
\text { counterpart }\end{array}$ & 126 \\
\hline 8 & $\mathrm{Mn}^{\mathrm{III}} \mathrm{SO}-\mathrm{DMF}$ & $\begin{array}{l}2,2 \text {-dimethyl- } \\
2 H_{\text {-chromene }}\end{array}$ & $\begin{array}{l}2 \text {-(tert- } \\
\text { butylsulfonyl) } \\
\text { iodosylbenzene }\end{array}$ & In $\mathrm{CH}_{2} \mathrm{Cl}_{2}$ & $4000^{*}$ & Epoxide(80) & $\begin{array}{l}\text { Very high } \\
\text { TON, } \\
\text { stopping only } \\
\text { due to the } \\
\text { depletion of } \\
\text { the oxidant }\end{array}$ & 123 \\
\hline 9 & $\mathrm{Mn}^{\mathrm{II}} \mathrm{SO}-\mathrm{DMF}$ & $\begin{array}{l}2,2 \text {-dimethyl- } \\
2 \mathrm{H} \text {-chromene }\end{array}$ & $\begin{array}{l}2 \text {-(tert- } \\
\text { butylsulfonyl) } \\
\text { iodosylbenzene }\end{array}$ & In $\mathrm{CH}_{2} \mathrm{Cl}_{2}$ & $750^{*}$ & $\begin{array}{l}\text { Epoxide } \\
(37)\end{array}$ & $\begin{array}{l}\text { Long } \\
\text { induction } \\
\text { period due to } \\
\text { oxidation of } \\
\mathrm{Mn}^{\mathrm{II}} \text { to } \mathrm{Mn}^{\mathrm{III}}\end{array}$ & $19 \mathrm{~b}$ \\
\hline 10 & Mn-salen@MIL-101(Al) & $\begin{array}{l}\text { Dihydronaphth } \\
\text { alene }\end{array}$ & $\begin{array}{l}\text { meta- } \\
\text { chloroperoxybenzo } \\
\text { icacid (MCPBA) } \\
\text { and N- } \\
\text { methylmorpholine } \\
\text { N-oxide(NMO) }\end{array}$ & $\mathrm{RT}, 2 \mathrm{~h}$ in $\mathrm{CH}_{2} \mathrm{Cl}_{2}$ & 69 & $\begin{array}{l}\text { Epoxide } \\
(70)\end{array}$ & $\begin{array}{l}\text { One-pot } \\
\text { encapsulatio } \\
\mathrm{n} \text { strategy, } \\
\text { the } \\
\text { encapsulatio } \\
\mathrm{n} \text { have no } \\
\text { effect on the } \\
\text { ee\% of the } \\
\text { homogeneous } \\
\text { catalyst. }\end{array}$ & 132 \\
\hline 11 & $\begin{array}{l}{\left[\mathrm{H}_{2} \mathrm{NMe}_{2}\right]_{2}\left[\mathrm{Cd}_{3}\left\{\mathrm{TiO}_{6}(\mathrm{TiL})_{3}\right\}(\mathrm{BP}\right.} \\
\mathrm{DC})_{3}\left(\mathrm{H}_{2} \mathrm{O}\right)_{3}\left(\mathrm{H}_{2} \mathrm{~L}=\text { salan ligand }\right. \\
\text { (scheme } 13 \mathrm{a}),)\end{array}$ & Sulfides & $30 \% \mathrm{H}_{2} \mathrm{O}_{2}$ & $\begin{array}{l}0^{\circ} \mathrm{C}, 72 \mathrm{~h} \text {, Solvent: } \\
\mathrm{CH}_{2} \mathrm{Cl}_{2} \\
\text { Substrate: } \\
\text { oxidant }=1: 1.2\end{array}$ & $23 \sim 90$ & $\begin{array}{l}\text { sulfoxides } \\
(67-82)\end{array}$ & $\begin{array}{l}\text { The MOF is } \\
\text { stable in } \\
\text { boiling } \mathrm{H}_{2} \mathrm{O} \\
\text { or } 30 \% \\
\text { aqueous } \\
\mathrm{H}_{2} \mathrm{O}_{2} \text { for } \\
3 \text { days) }\end{array}$ & 127 \\
\hline 12 & $\begin{array}{l}\mathrm{Cd}_{3}\left(\mathrm{~m}_{3}-\mathrm{OH}\right) \mathrm{Br}\left[(\mathrm{TiLOMe})_{2} \mathrm{O}\right]_{2} \\
\left(\mathrm{H}_{2} \mathrm{~L}=\text { salan ligand, (scheme }\right. \\
13 \mathrm{~d}) \text {, }\end{array}$ & Sulfides & $30 \% \mathrm{H}_{2} \mathrm{O}_{2}$ & $\begin{array}{l}0^{\circ} \mathrm{C}, \quad 16 \mathrm{~h}, \\
\text { Substrate: } \\
\text { oxidant=1:1.15 }\end{array}$ & $54 \sim 90$ & $\begin{array}{l}\text { sulfoxides } \\
(23 \sim 62)\end{array}$ & $\begin{array}{l}\text { Recycled } \\
\text { upto 4runs. } \\
\text { The MOF } \\
\text { catalyst } \\
\text { shows } \\
\text { improved } \\
\text { enantioselect }\end{array}$ & 128 \\
\hline
\end{tabular}




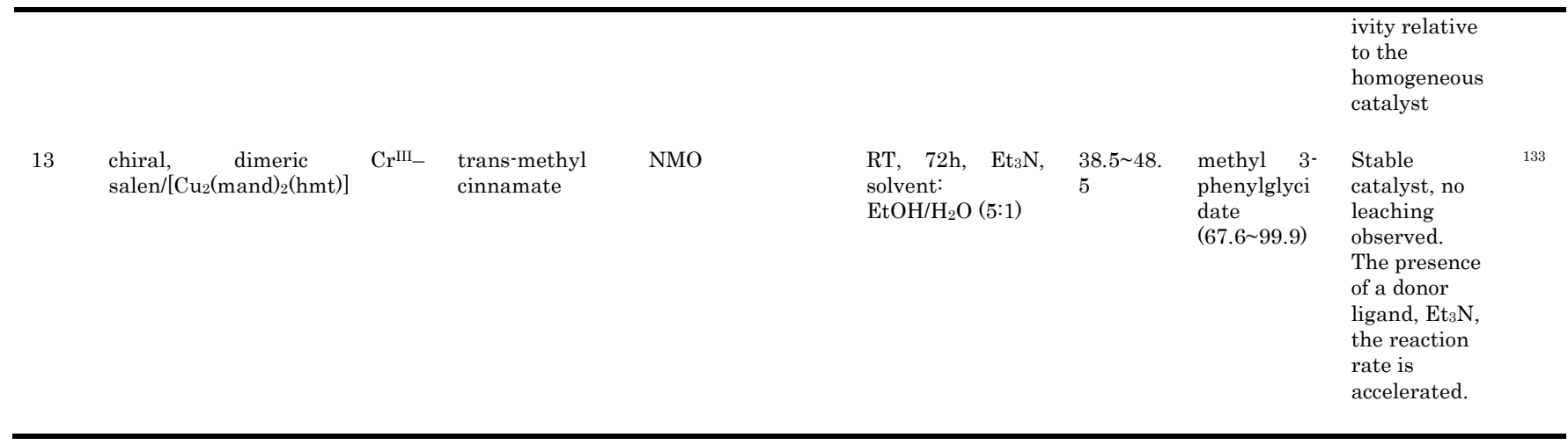

* TON value

\section{Conclusions and perspectives}

From this review, it can be concluded that there is an enormous growth of reports on MOFs in oxidation catalysis. Different types of substrates have already been examined (alcohols, alkenes, alkanes, thiols and sulfides..) in which MOFs were examined as such (e.g. MIL-101, Fe(BTC), MIL47..) or served as a matrix for the incapsulation or post-modification with a homogeneous catalyst. In many of these reports the MOFs showed promising results in terms of activity, selectivity and stability. Nevertheless, to be able to compete with the industrial catalysts and to explore their industrial relevance, it is important that longer and more catalytic cycles are carried out in contrast to the few cycles (3-10 runs) presented now. At this moment, very few papers address the comparison of the MOF material with catalysts used in industry (e.g. zeolites, zeotypes, silica based materials). Most of the reports compare the catalytic activity of the MOF with the homogeneous counterpart or metal oxides.

In addition to this, more in depth studies are definitely required on the nature of the active site. In other words, a combined experimental and theoretical study to elucidate the catalytic mechanism is of a paramount importance. Within the concept of green chemistry, more efforts should be carried out to perform the oxidation reactions with clean oxidants like $\mathrm{H}_{2} \mathrm{O}_{2}$ or oxygen. Their use is probably hampered due to the very few MOFs which are known to be stable in water or air. We witness therefore a shift is research focus: in contrast to the original aim to design MOFs with unsaturated metal sites for catalytic applications, research groups are performing nowadays more efforts to enhance the intrinsic stability of the framework. This can be done by selecting a more rigid SBU or by performing a post-modification of a known stable framework. Only a few very stable frameworks have been reported, they include amongst others the UiO-66 (Zr) and several variants for the MIL-101 and MIL-100 (Cr, Al).

At this moment, the use of MOFs as chiral oxidation catalysts is still in an early stage, nevertheless the results reported so far show promising results in terms of an enhanced lifetime of the chiral MOF catalyst and similar ee values in comparison to the homogeneous counterpart. We believe that chiral and selective catalysis for the production of fine chemicals will be one of the most promising directions, hereby heterogenizing the fragile homogeneous complexes that are now used. In these mild, liquid phase conditions, catalyst attrition will be minimal and we have discussed in this review several studies that have shown that the $e e$ or selectivity can be retained with respect to the original complex, the activity drops only marginally and the catalysts is reusable multiple times. Two distinct routes are 
possible: one can create exciting chiral MOF structures with chiral struts and designed pore size to outperform the homogeneous complexes, one can also follow very simple encapsulation routes in pore designed MOFs, with complete retention of selectivity. The big advantage of designability and functionalizabilty of MOFs compared to zeolites should be more and more exploited by employing reactants in which chemo, regio and stereo selectivity aspects can be achieved.

\section{Acknowledgments}

Ying-Ya Liu acknowledges the Ghent University BOF postdoctoral Grant (Nr. 01P02911T) and the Fundamental Research Fund for the Central Universities of China (DUT13RC(3)85). Karen Leus acknowledges the Ghent University GOA Grant (Nr. 01G00710) and the Ghent University BOF postdoctoral Grant (Nr. 01P068135).

\section{References}

(1) (a) Zhao, X. S.; Bao, X. Y.; Guo, W.; Lee, F. Y. Materials Today 2006, 9, 32(b) Corma, A.; García, H. Chemical Reviews 2002, 102, 3837.

(2) (a) Chen, M. S.; Goodman, D. W. Science 2004, 306, 252(b) Min, B. K.; Friend, C. M. Chemical Reviews 2007, 107, 2709.

(3) (a) Cavka, J. H.; Jakobsen, S.; Olsbye, U.; Guillou, N.; Lamberti, C.; Bordiga, S.; Lillerud, K. P. Journal of the American Chemical Society 2008, 130, 13850(b) Valenzano, L.; Civalleri, B.; Chavan, S.; Bordiga, S.; Nilsen, M. H.; Jakobsen, S.; Lillerud, K. P.; Lamberti, C. Chemistry of Materials 2011, 23, 1700.

(4) Loiseau, T.; Serre, C.; Huguenard, C.; Fink, G.; Taulelle, F.; Henry, M.; Bataille, T.; Ferey, G. Chem-Eur J 2004, 10, 1373.

(5) Rosi, N. L.; Kim, J.; Eddaoudi, M.; Chen, B.; O'Keeffe, M.; Yaghi, O. M. Journal of the American Chemical Society 2005, 127, 1504.

(6) (a) Long, J. R.; Yaghi, O. M. Chem Soc Rev 2009, 38, 1213(b) Tanabe, K. K.; Cohen, S. M. Chem Soc Rev 2011, 40, 498(c) Rowsell, J. L. C.; Yaghi, O. M. Micropor Mesopor Mat 2004, 73,3 .

(7) (a) Li, H.; Eddaoudi, M.; O'Keeffe, M.; Yaghi, O. M. Nature 1999, 402, 276(b) Hupp, J. T.; Farha, O. K. Accounts Chem Res 2010, 43, 1166.

(8) Farha, O. K.; Eryazici, I.; Jeong, N. C.; Hauser, B. G.; Wilmer, C. E.; Sarjeant, A. A.; Snurr, R. Q.; Nguyen, S. T.; Yazaydin, A. O.; Hupp, J. T. Journal of the American Chemical Society 2012, 134, 15016.

(9) (a) Doonan, C. J.; Morris, W.; Furukawa, H.; Yaghi, O. M. Journal of the American Chemical Society 2009, 131, 9492(b) Eddaoudi, M.; Kim, J.; Rosi, N.; Vodak, D.; Wachter, J.; O'Keeffe, M.; Yaghi, O. M. Science 2002, 295, 469.

(10) Chem Soc Rev 2009, 1201.

(11) Tonigold, M.; Lu, Y.; Bredenkotter, B.; Rieger, B.; Bahnmuller, S.; Hitzbleck, J.; Langstein, G.; Volkmer, D. Angew Chem Int Edit 2009, 48, 7546.

(12) Ma, L.; Abney, C.; Lin, W. Chem Soc Rev 2009, 38, 1248.

(13) Gomes Silva, C.; Luz, I.; Llabrés i Xamena, F. X.; Corma, A.; García, H. Chemistry - A European Journal 2010, 16, 11133.

(14) Gandara, F.; Puebla, E. G.; Iglesias, M.; Proserpio, D. M.; Snejko, N.; Monge, M. A. Chemistry of Materials 2009, 21, 655.

(15) Férey, G.; Mellot-Draznieks, C.; Serre, C.; Millange, F.; Dutour, J.; Surblé, S.; Margiolaki, I. Science 2005, 309, 2040.

(16) Chui, S. S. Y.; Lo, S. M. F.; Charmant, J. P. H.; Orpen, A. G.; Williams, I. D. Science 1999, $283,1148$. 
(17) (a) Banerjee, M.; Das, S.; Yoon, M.; Choi, H. J.; Hyun, M. H.; Park, S. M.; Seo, G.; Kim, K. Journal of the American Chemical Society 2009, 131, 7524(b) Hong, D.-Y.; Hwang, Y. K.; Serre, C.; Ferey, G.; Chang, J.-S. Advanced Functional Materials 2009, 19, 1537(c) Marx, S.; Kleist, W.; Baiker, A. J Catal 2011, 281, 76(d) Noei, H.; Amirjalayer, S.; Mueller, M.; Zhang, X.; Schmid, R.; Muhler, M.; Fischer, R. A.; Wang, Y. Chemcatchem 2012, 4, 755.

(18) (a) Kim, M.; Cahill, J. F.; Fei, H. H.; Prather, K. A.; Cohen, S. M. Journal of the American Chemical Society 2012, 134, 18082(b) Gandara, F.; de Andres, A.; Gomez-Lor, B.; GutierrezPuebla, E.; Iglesias, M.; Monge, M. A.; Proserpio, D. M.; Snejko, N. Cryst Growth Des 2008, $8,378$.

(19) (a) Juan-Alcaniz, J.; Ramos-Fernandez, E. V.; Lafont, U.; Gascon, J.; Kapteijn, F. Journal of Catalysis 2010, 269, 229(b) Shultz, A. M.; Sarjeant, A. A.; Farha, O. K.; Hupp, J. T.; Nguyen, S. T. Journal of the American Chemical Society 2011, 133, 13252(c) Kong, X.-J.; Ren, Y.-P.; Zheng, P.-Q.; Long, Y.-X.; Long, L.-S.; Huang, R.-B.; Zheng, L.-S. Inorganic Chemistry 2006, 45, 10702(d) Marleny Rodriguez-Albelo, L.; Rabdel Ruiz-Salvador, A.; Sampieri, A.; Lewis, D. W.; Gomez, A.; Nohra, B.; Mialane, P.; Marrot, J.; Secheresse, F.; Mellot-Draznieks, C.; Biboum, R. N.; Keita, B.; Nadjo, L.; Dolbecq, A. Journal of the American Chemical Society 2009, 131, 16078(e) Sun, C.-Y.; Liu, S.-X.; Liang, D.-D.; Shao, K.-Z.; Ren, Y.-H.; Su, Z.-M. Journal of the American Chemical Society 2009, 131, 1883(f) Wang, C.; Xie, Z.; deKrafft, K. E.; Lin, W. Journal of the American Chemical Society 2011, 133, 13445(g) Moon, H. R.; Lim, D.-W.; Suh, M. P. Chem Soc Rev 2013, 42, 1807(h) Alkordi, M. H.; Liu, Y. L.; Larsen, R. W.; Eubank, J. F.; Eddaoudi, M. Journal of the American Chemical Society 2008, 130, 12639.

(20) (a) Ma, L.; Falkowski, J. M.; Abney, C.; Lin, W. Nature Chemistry 2010, 2, 838(b) Carson, F.; Agrawal, S.; Gustafsson, M.; Bartoszewicz, A.; Moraga, F.; Zou, X.; Martin-Matute, B. ChemEur J 2012, 18, 15337.

(21) (a) Esken, D.; Turner, S.; Lebedev, O. I.; Van Tendeloo, G.; Fischer, R. A. Chemistry of Materials 2010, 22, 6393(b) Dhakshinamoorthy, A.; Alvaro, M.; Garcia, H. Chem Commun 2010, 46, 6476(c) Dhakshinamoorthy, A.; Alvaro, M.; Horcajada, P.; Gibson, E.; Vishnuvarthan, M.; Vimont, A.; Greneche, J. M.; Serre, C.; Daturi, M.; Garcia, H. Acs Catal 2012, 2, 2060(d) Song, J.; Luo, Z.; Britt, D. K.; Furukawa, H.; Yaghi, O. M.; Hardcastle, K. I.; Hill, C. L. Journal of the American Chemical Society 2011, 133, 16839(e) Bernini, M. C.; Gandara, F.; Iglesias, M.; Snejko, N.; Gutierrez-Puebla, E.; Brusau, E. V.; Narda, G. E.; Monge, M. A. Chem-Eur J 2009, 15, 4896(f) Lee, J.; Farha, O. K.; Roberts, J.; Scheidt, K. A.; Nguyen, S. T.; Hupp, J. T. Chem Soc Rev 2009, 38, 1450(g) Corma, A.; Garcia, H.; Llabres i Xamena, F. X. Chemical Reviews 2010, 110, 4606(h) Dhakshinamoorthy, A.; Garcia, H. Chem Soc Rev 2012, 41, 5262.

(22) Dhakshinamoorthy, A.; Alvaro, M.; Garcia, H. Catal Sci Technol 2011, 1, 856.

(23) Dhakshinamoorthy, A.; Opanasenko, M.; Cejka, J.; Garcia, H. Catal Sci Technol 2013, 3, 2509.

(24) Oyama, S. T.; Elsevier, 2008.

(25) Fujishima, A.; Zhang, X.; Tryk, D. A. Surface Science Reports 2008, 63, 515.

(26) Robert, D.; Malato, S. The Science of the Total Environment 2002, 291, 85.

(27) (a) Lassila, K. R.; Waller, F. J.; Werkheiser, S. E.; Wressell, A. L. Tetrahedron Letters 1994, 8077(b) Wentzel, B. B.; Alsters, P. L.; Feiters, M. C.; Nolte, R. J. M. Journal of Organic Chemistry 2004, 69, 3453.

(28) (a) Che, C. M.; Lo, V. K. Y.; Zhou, C. Y.; Huang, J. S. Chem Soc Rev 2011, 40, 1950(b) Li, H.; She, Y.; Wang, T. Frontiers of Chemical Science and Engineering 2012, 6, 356.

(29) Xamena, F. X. L. I.; Casanova, O.; Tailleur, R. G.; Garcia, H.; Corma, A. Journal of Catalysis 2008, 255, 220.

(30) Kim, J.; Bhattacharjee, S.; Jeong, K. E.; Jeong, S. Y.; Ahn, W. S. Chem Commun 2009, 3904.

(31) Ryan, P.; Konstantinov, I.; Snurr, R. Q.; Broadbelt, L. J. Journal of Catalysis 2012, $286,95$.

(32) Dhakshinamoorthy, A.; Alvaro, M.; Garcia, H. Journal of Catalysis 2009, 267, 1.

(33) Dhakshinamoorthy, A.; Alvaro, M.; Hwang, Y. K.; Seo, Y. K.; Corma, A.; Garcia, H. Dalton T 2011, 40, 10719.

(34) Wang, S. J.; Li, L.; Zhang, J. Y.; Yuan, X. C.; Su, C. Y. J Mater Chem 2011, 21, 7098. 
(35) Yu, F.; Zheng, P. Q.; Long, Y. X.; Ren, Y. P.; Kong, X. J.; Long, L. S.; Yuan, Y. Z.; Huang, R. B.; Zheng, L. S. Eur J Inorg Chem 2010, 4526.

(36) Dhakshinamoorthy, A.; Alvaro, M.; Garcia, H. Chem-Eur J 2011, 17, 6256.

(37) Ishii, Y.; Iwahama, T.; Sakaguchi, S.; Nakayama, K.; Nishiyama, Y. Journal of Organic Chemistry 1996, 61, 4520.

(38) Dhakshinamoorthy, A.; Alvaro, M.; Garcia, H. Chemcatchem 2010, 2, 1438.

(39) (a) Ishii, Y.; Sakaguchi, S.; Iwahama, T. Adv Synth Catal 2001, 343, 393(b) Biswas, S.; Maes, M.; Dhakshinamoorthy, A.; Feyand, M.; De Vos, D. E.; Garcia, H.; Stock, N. J Mater Chem 2012, 22, 10200.

(40) Nakagaki, S.; Baio Ferreira, G. K.; Ucoski, G. M.; Dias de Freitas Castro, K. A. Molecules 2013, 18, 7279 .

(41) Yang, X.-L.; Xie, M.-H.; Zou, C.; He, Y.; Chen, B.; O'Keeffe, M.; Wu, C.-D. Journal of the American Chemical Society 2012, 134, 10638.

(42) Zou, C.; Zhang, T.; Xie, M.-H.; Yan, L.; Kong, G.-Q.; Yang, X.-L.; Ma, A.; Wu, C.-D. Inorganic Chemistry 2013, 52, 3620.

(43) Luz, I.; Leon, A.; Boronat, M.; Llabres i Xamena, F. X.; Corma, A. Catal Sci Technol 2013, 3, 371.

(44) Di Nicola, C.; Karabach, Y. Y.; Kirillov, A. M.; Monari, M.; Pandolfo, L.; Pettinari, C.; Pombeiro, A. J. L. Inorganic Chemistry 2007, 46, 221.

(45) Kockrick, E.; Lescouet, T.; Kudrik, E. V.; Sorokin, A. B.; Farrusseng, D. Chem Commun 2011, 47, 1562.

(46) Liu, H.; Li, Y.; Jiang, H.; Vargas, C.; Luque, R. Chem Commun 2012, 48, 8431.

(47) Long, J.; Wang, L.; Gao, X.; Bai, C.; Jiang, H.; Li, Y. Chem Commun 2012, 48, 12109.

(48) Nguyen, H. G. T.; Weston, M. H.; Sarjeant, A. A.; Gardner, D. M.; An, Z.; Carmieli, R.; Wasielewski, M. R.; Farha, O. K.; Hupp, J. T.; Nguyen, S. T. Cryst Growth Des 2013, 13, 3528.

(49) Sun, Z.; Li, G.; Liu, L.; Liu, H.-o. Catalysis Communications 2012, 27, 200.

(50) Arends, I. W. C. E.; Sheldon, R. A. Modern oxidation of alcohols using environmentally benign oxidants, Chapter 5 in "Modern Oxidation Methods (2nd edition); Wiley-VCH, Weinheim 2010.

(51) (a) Mallat, T.; Baiker, A. Chemical Reviews 2004, 104, 3037(b) Sheldon, R. A.; Arends, I. W. C. E.; Ten Brink, G. J.; Dijksman, A. Accounts Chem Res 2002, 35, 774.

(52) Ji, H. B.; Ebitani, K.; Mizugaki, T.; Kaneda, K. Catalysis Communications 2002, 3, 511.

(53) Xamena, F. X. L. I.; Abad, A.; Corma, A.; Garcia, H. Journal of Catalysis 2007, 250, 294.

(54) Bloch, E. D.; Britt, D.; Lee, C.; Doonan, C. J.; Uribe-Romo, F. J.; Furukawa, H.; Long, J. R.; Yaghi, O. M. Journal of the American Chemical Society 2010, 132, 14382.

(55) Miyamura, H.; Matsubara, R.; Miyazaki, Y.; Kobayashi, S. Angew Chem Int Edit 2007, 46, 4151.

(56) Proch, S.; Herrmannsdorfer, J.; Kempe, R.; Kern, C.; Jess, A.; Seyfarth, L.; Senker, J. ChemEur J 2008, 14, 8204.

(57) Dhakshinamoorthy, A.; Alvaro, M.; Garcia, H. Acs Catal 2011, 1, 48.

(58) Muller, M.; Turner, S.; Lebedev, O. I.; Wang, Y. M.; van Tendeloo, G.; Fischer, R. A. Eur J Inorg Chem 2011, 1876.

(59) Liu, H. L.; Liu, Y. L.; Li, Y. W.; Tang, Z. Y.; Jiang, H. F. J Phys Chem C 2010, 114, 13362.

(60) (a) Corma, A.; Garcia, H. Chem Soc Rev 2008, 37, 2096(b) Abad, A.; Concepcion, P.; Corma, A.; Garcia, H. Angew Chem Int Edit 2005, 44, 4066(c) Abad, A.; Corma, A.; Garcia, H. ChemEur J 2008, 14, 212(d) Boronat, M.; Concepcion, P.; Corma, A.; Gonzalez, S.; Illas, F.; Serna, P. Journal of the American Chemical Society 2007, 129, 16230.

(61) Ishida, T.; Nagaoka, M.; Akita, T.; Haruta, M. Chem-Eur J 2008, 14, 8456.

(62) Jeong, H. C.; Shim, I. W.; Choi, K. Y.; Lee, J. K.; Park, J. N.; Lee, C. W. Korean J Chem Eng 2005, 22, 657.

(63) Preethi, M. E. L.; Revathi, S.; Sivakumar, T.; Manikandan, D.; Divakar, D.; Rupa, A. V.; Palanichami, M. Catal Lett 2008, 120, 56. 
(64) (a) Qiu, L. G.; Xie, A. J.; Zhang, L. D. Adv Mater 2005, 17, 689(b) Qiu, L. G.; Gu, L. N.; Hu, G.; Zhang, L. D. J Solid State Chem 2009, 182, 502(c) Bi, J. H.; Kong, L. T.; Huang, Z. X.; Liu, J. H. Inorganic Chemistry 2008, 47, 4564.

(65) Bhattacharjee, S.; Choi, J. S.; Yang, S. T.; Choi, S. B.; Kim, J.; Ahn, W. S. J Nanosci Nanotechno 2010, 10, 135.

(66) Kulawong, S.; Prayoonpokarach, S.; Neramittagapong, A.; Wittayakun, J. J Ind Eng Chem 2011, 17, 346.

(67) Xie, M.-H.; Yang, X.-L.; Zou, C.; Wu, C.-D. Inorganic Chemistry 2011, 50, 5318.

(68) Long, J.; Wang, S.; Ding, Z.; Wang, S.; Zhou, Y.; Huang, L.; Wang, X. Chem Commun 2012, $48,11656$.

(69) Jian, L. J.; Chen, C.; Lan, F.; Deng, S. J.; Xiao, W. M.; Zhang, N. Solid State Sci 2011, 13, 1127.

(70) Chen, G.; Wu, S.; Liu, H.; Jiang, H.; Li, Y. Green Chemistry 2013, 15, 230.

(71) Mariana Balu, A.; Lin, C. S. K.; Liu, H.; Li, Y.; Vargas, C.; Luque, R. Applied Catalysis aGeneral 2013, 455, 261.

(72) Nguyen, H. G. T.; Weston, M. H.; Farha, O. K.; Hupp, J. T.; Nguyen, S. T. Crystengcomm 2012, 14, 4115.

(73) (a) Perles, J.; Iglesias, M.; Martin-Luengo, M. A.; Monge, M. A.; Ruiz-Valero, C.; Snejko, N. Chemistry of Materials 2005, 17, 5837(b) Perles, J.; Iglesias, M.; Ruiz-Valero, C.; Snejko, N. J Mater Chem 2004, 14, 2683.

(74) Perles, J.; Snejko, N.; Iglesias, M.; Monge, M. A. J Mater Chem 2009, 19, 6504.

(75) Hwang, Y. K.; Hong, D. Y.; Chang, J. S.; Seo, H.; Yoon, M.; Kim, J.; Jhung, S. H.; Serre, C.; Ferey, G. Applied Catalysis a-General 2009, 358, 249.

(76) Nuzhdin, A. L.; Dybtsev, D. N.; Fedin, V. P.; Bukhtiyarova, G. A. Dalton T 2009, 10481.

(77) Ribeiro, S.; Granadeiro, C. M.; Silva, P.; Almeida Paz, F. A.; de Biani, F. F.; Cunha-Silva, L.; Balula, S. S. Catal Sci Technol 2013, 3, 2404.

(78) Liu, D.; Lu, Y.; Tan, H.-Q.; Chen, W.-L.; Zhang, Z.-M.; Li, Y.-G.; Wang, E.-B. Chem Commun 2013, 49, 3673.

(79) Hu, X.; Lu, Y.; Dai, F.; Liu, C.; Liu, Y. Micropor Mesopor Mat 2013, 170, 36.

(80) Fazaeli, R.; Aliyan, H.; Moghadam, M.; Masoudinia, M. Journal of Molecular Catalysis aChemical 2013, 374, 46.

(81) Ozbek, M. O.; Onal, I.; van Santen, R. A. Chemcatchem 2011, 3, 150.

(82) (a) Aprile, C.; Corma, A.; Domine, M. E.; Garcia, H.; Mitchell, C. Journal of Catalysis 2009, 264, 44(b) Ojeda, M.; Iglesia, E. Chem Commun 2009, 352.

(83) Zhang, W.; Loebach, J. L.; Wilson, S. R.; Jacobsen, E. N. Journal of the American Chemical Society 1990, 112, 2801.

(84) Ramos-Fernandez, E. V.; Garcia-Domingos, M.; Juan-Alcaniz, J.; Gascon, J.; Kapteijn, F. Applied Catalysis a-General 2011, 391, 261.

(85) Jiang, D. M.; Mallat, T.; Meier, D. M.; Urakawa, A.; Baiker, A. Journal of Catalysis 2010, $270,26$.

(86) Baca, S. G.; Reetz, M. T.; Goddard, R.; Filippova, I. G.; Simonov, Y. A.; Gdaniec, M.; Gerbeleu, N. Polyhedron 2006, 25, 1215.

(87) Aguirre, P.; Brown, K.; Venegas-Yazigi, D.; Paredes-Garcia, V.; Spodine, E. Macromol Symp 2011, 304, 65.

(88) Brown, K.; Zolezzi, S.; Aguirre, P.; Venegas-Yazigi, D.; Paredes-Garcia, V.; Baggio, R.; Novak, M. A.; Spodine, E. Dalton T 2009, 1422.

(89) Fu, Y. H.; Sun, D. R.; Qin, M.; Huang, R. K.; Li, Z. H. Rsc Adv 2012, 2, 3309.

(90) Lu, Y.; Tonigold, M.; Bredenkotter, B.; Volkmer, D.; Hitzbleck, J.; Langstein, G. Z Anorg Allg Chem 2008, 634, 2411.

(91) Tonigold, M.; Lu, Y.; Mavrandonakis, A.; Puls, A.; Staudt, R.; Mollmer, J.; Sauer, J.; Volkmer, D. Chem-Eur J 2011, 17, 8671.

(92) Zhang, A. P.; Li, L. Q.; Li, J.; Zhang, Y.; Gao, S. Catalysis Communications 2011, 12, 1183. 
(93) Beier, M. J.; Kleist, W.; Wharmby, M. T.; Kissner, R.; Kimmerle, B.; Wright, P. A.; Grunwaldt, J. D.; Baiker, A. Chem-Eur J 2012, 18, 887.

(94) Sen, R.; Koner, S.; Hazra, D. K.; Helliwell, M.; Mukherjee, M. Eur J Inorg Chem 2011, 241.

(95) Sen, R.; Saha, D.; Koner, S. Catal Lett 2012, 142, 124.

(96) (a) Leus, K.; Muylaert, I.; Vandichel, M.; Marin, G. B.; Waroquier, M.; Van Speybroeck, V.; Van der Voort, P. Chem Commun 2010, 46, 5085(b) Leus, K.; Muylaert, I.; Van Speybroeck, V.; Marin, G. B.; Van der Voort, P. Stud Surf Sci Catal 2010, 175, 329(c) Leus, K.; Vandichel, M.; Liu, Y. Y.; Muylaert, I.; Musschoot, J.; Pyl, S.; Vrielinck, H.; Callens, F.; Marin, G. B.; Detavernier, C.; Wiper, P. V.; Khimyak, Y. Z.; Waroquier, M.; Van Speybroeck, V.; Van der Voort, P. Journal of Catalysis 2012, 285, 196.

(97) Liu, Y. Y.; Leus, K.; Grzywa, M.; Weinberger, D.; Strubbe, K.; Vrielinck, H.; Van Deun, R.; Volkmer, D.; Van Speybroeck, V.; Van der Voort, P. Eur J Inorg Chem 2012, 16, 2819.

(98) Leus, K.; Vanhaelewyn, G.; Bogaerts, T.; Liu, Y. Y.; Esquivel, D.; Callens, F.; Marin, G. B.; Van Speybroeck, V.; Vrielinck, H.; Van Der Voort, P. Catalysis Today 2012.

(99) Maksimchuk, N. V.; Timofeeva, M. N.; Melgunov, M. S.; Shmakov, A. N.; Chesalov, Y. A.; Dybtsev, D. N.; Fedin, V. P.; Kholdeeva, O. A. Journal of Catalysis 2008, 257, 315.

(100) Maksimchuk, N. V.; Kovalenko, K. A.; Arzumanov, S. S.; Chesalov, Y. A.; Melgunov, M. S.; Stepanov, A. G.; Fedin, V. P.; Kholdeeva, O. A. Inorganic Chemistry 2010, 49, 2920.

(101) Bromberg, L.; Diao, Y.; Wu, H. M.; Speakman, S. A.; Hatton, T. A. Chemistry of Materials 2012, 24, 1664.

(102) Maksimchuk, N. V.; Zalomaeva, O. V.; Skobelev, I. Y.; Kovalenko, K. A.; Fedin, V. P.; Kholdeeva, O. A. P Roy Soc a-Math Phy 2012, 468, 2017.

(103) Dhakshinamoorthy, A.; Alvaro, M.; Garcia, H. Acs Catal 2011, 1, 836.

(104) Ingleson, M. J.; Barrio, J. P.; Guilbaud, J. B.; Khimyak, Y. Z.; Rosseinsky, M. J. Chem Commun 2008, 2680.

(105) Bhattacharjee, S.; Yang, D. A.; Ahn, W. S. Chem Commun 2011, 47, 3637.

(106) Lee, D. H.; Kim, S.; Hyun, M. Y.; Hong, J. Y.; Huh, S.; Kim, C.; Lee, S. J. Chem Commun 2012, 48, 5512.

(107) Farha, O. K.; Shultz, A. M.; Sarjeant, A. A.; Nguyen, S. T.; Hupp, J. T. Journal of the American Chemical Society 2011, 133, 5652.

(108) Meng, L.; Cheng, Q. G.; Kim, C.; Gao, W. Y.; Wojtas, L.; Chen, Y. S.; Zaworotko, M. J.; Zhang, X. P.; Ma, S. Q. Angew Chem Int Edit 2012, 51, 10082.

(109) Lee, J. S.; Halligudi, S. B.; Jang, N. H.; Hwang, D. W.; Chang, J. S.; Hwang, Y. K. B Korean Chem Soc 2010, 31, 1489.

(110) Hosseini Monfared, H.; Mohajeri, A.; Morsali, A.; Janiak, C. Monatsh Chem 2009, 140, 1437.

(111) Zhang, Z. J.; Zhang, L. P.; Wojtas, L.; Eddaoudi, M.; Zaworotko, M. J. Journal of the American Chemical Society 2012, 134, 928.

(112) Granadeiro, C. M.; Barbosa, A. D. S.; Silva, P.; Paz, F. A. A.; Saini, V. K.; Fires, J.; de Castro, B.; Balula, S. S.; Cunha-Silva, L. Applied Catalysis a-General 2013, 453, 316.

(113) Khajavi, H.; Gascon, J.; Schins, J. M.; Siebbeles, L. D. A.; Kapteijn, F. J Phys Chem C 2011, $115,12487$.

(114) Gascon, J.; Hernandez-Alonso, M. D.; Almeida, A. R.; van Klink, G. P. M.; Kapteijn, F.; Mul, G. Chemsuschem 2008, 1, 981.

(115) Zhang, G.; Li, H.; Zhao, F.; Hu, H.; Huang, H.; Li, H.; Han, X.; Liu, R.; Dong, H.; Liu, Y.; Kang, Z. Dalton T 2013, 42, 9423.

(116) (a) Tang, Q. H.; Wang, Y.; Liang, J.; Wang, P.; Zhang, Q. H.; Wan, H. L. Chem Commun 2004, 440(b) Salavati-Niasari, M.; Abdolmohammadi, S.; Oftadeh, M. J Coord Chem 2008, 61, 2837(c) Patil, M. V.; Yadav, M. K.; Jasra, R. V. Journal of Molecular Catalysis a-Chemical 2007, 277, 72(d) Jinka, K. M.; Sebastian, J.; Jasra, R. V. Journal of Molecular Catalysis aChemical 2007, 274, 33.

(117) (a) Diez, D.; Nunez, M. G.; Anton, A. B.; Garcia, P.; Moro, R. F.; Garrido, N. M.; Marcos, I. S.; Basabe, P.; Urones, J. G. Curr Org Synth 2008, 5, 186(b) Bougauchi, M.; Watanabe, S.; Arai, T.; Sasai, H.; Shibasaki, M. Journal of the American Chemical Society 1997, 119, 2329. 
(118) Loiseau, T.; Mellot-Draznieks, C.; Muguerra, H.; Ferey, G.; Haouas, M.; Taulelle, F. Cr Chim 2005, 8, 765 .

(119) Yoon, M.; Srirambalaji, R.; Kim, K. Chemical Reviews 2012, 112, 1196.

(120) Cho, S. H.; Ma, B. Q.; Nguyen, S. T.; Hupp, J. T.; Albrecht-Schmitt, T. E. Chem Commun 2006, 2563.

(121) Oxford, G. A. E.; Dubbeldam, D.; Broadbelt, L. J.; Snurr, R. Q. Journal of Molecular Catalysis a-Chemical 2011, 334, 89.

(122) Cho, S. H.; Gadzikwa, T.; Afshari, M.; Nguyen, S. T.; Hupp, J. T. Eur J Inorg Chem 2007, 4863.

(123) Shultz, A. M.; Farha, O. K.; Adhikari, D.; Sarjeant, A. A.; Hupp, J. T.; Nguyen, S. T. Inorganic Chemistry 2011, 50, 3174.

(124) Song, F. J.; Wang, C.; Falkowski, J. M.; Ma, L. Q.; Lin, W. B. Journal of the American Chemical Society 2010, 132, 15390.

(125) Song, F. J.; Wang, C.; Lin, W. B. Chem Commun 2011, 47, 8256.

(126) Huang, Y. B.; Liu, T. F.; Lin, J. X.; Lu, J. A.; Lin, Z. J.; Cao, R. Inorganic Chemistry 2011, 50, 2191.

(127) Xuan, W.; Ye, C.; Zhang, M.; Chen, Z.; Cui, Y. Chemical Science 2013, 4, 3154.

(128) Zhu, C.; Chen, X.; Yang, Z.; Du, X.; Liu, Y.; Cui, Y. Chem Commun 2013, 49, 7120.

(129) Dybtsev, D. N.; Nuzhdin, A. L.; Chun, H.; Bryliakov, K. P.; Talsi, E. P.; Fedin, V. P.; Kim, K. Angew Chem Int Edit 2006, 45, 916.

(130) Nuzhdin, A. L.; Dybtsev, D. N.; Bryliakov, K. P.; Talsi, E. P.; Fedin, V. P. Journal of the American Chemical Society 2007, 129, 12958.

(131) Dybtsev, D. N.; Yutkin, M. P.; Samsonenko, D. G.; Fedin, V. P.; Nuzhdin, A. L.; Bezrukov, A. A.; Bryliakov, K. P.; Talsi, E. P.; Belosludov, R. V.; Mizuseki, H.; Kawazoe, Y.; Subbotin, O. S.; Belosludov, V. R. Chem-Eur J 2010, 16, 10348.

(132) Bogaerts, T.; Van Yperen-De Deyne, A.; Liu, Y.-Y.; Lynen, F.; Van Speybroeck, V.; Van Der Voort, P. Chem Commun 2013, 49, 8021.

(133) Candu, N.; Tudorache, M.; Florea, M.; Ilyes, E.; Vasiliu, F.; Mercioniu, I.; Coman, S. M.; Haiduc, I.; Andruh, M.; Parvulescu, V. I. Chempluschem 2013, 78, 443. 